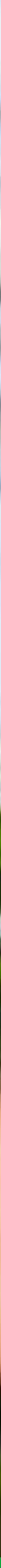

\title{
Energiemonitor van de Nederlandse glastuinbouw 2019
}





\section{Energiemonitor van de Nederlandse glastuinbouw 2019}

Nico van der Velden en Pepijn Smit

Dit onderzoek is uitgevoerd door Wageningen Economic Research in opdracht van de Stichting Kennis in je Kas van de glastuinbouwsector en met subsidie van het Ministerie van Landbouw, Natuur en Voedselkwaliteit.

Wageningen Economic Research

Wageningen, november 2020

RAPPORT

2020-109

ISBN 978-94-6395-598-0 
Van der Velden, Nico en Smit, Pepijn, 2020. Energiemonitor van de Nederlandse glastuinbouw 2019. Wageningen, Wageningen Economic Research, Rapport 2020-109. 66 blz.; 28 fig.; 5 tab.; 15 ref.

Tussen glastuinbouwsector en overheid is een doel voor de $\mathrm{CO}_{2}$-emissie in 2020 overeengekomen. In 2017 is dit doel technisch gecorrigeerd naar 4,6 Mton. In 2019 is de $\mathrm{CO}_{2}$-emissie gestegen naar 5,9 Mton en deze zat hiermee 1,2 Mton boven het doel voor 2020 en 0,3 Mton onder het doel voor de technische correctie (6,2 Mton). In 2019 steeg de $\mathrm{CO}_{2}$-emissie vooral door toename van het areaal. De $\mathrm{CO}_{2}$-emissie nam ook toe doordat er meer elektriciteit verkocht werd en de inkoop van nietduurzame warmte afnam. De groei van duurzame energie en van inkoop elektriciteit compenseerde deels de toegenomen $\mathrm{CO}_{2}$-emissie. Het aandeel duurzame energie in het totaal energiegebruik groeide in 2019 sterk naar 9,4\%. Aardwarmte was de belangrijkste duurzame bron en de groei zat vooral bij inkoop duurzame warmte. De energie-efficiëntie verslechterde in 2019 met 1 procentpunt. De elektriciteitsproductie $(10,5$ miljard kWh) was niet eerder zo hoog. Het aandeel van aardgas in de energievoorziening daalde in de periode $2010-2019$ van $88 \%$ naar $78 \%$.

Trefwoorden: energie, $\mathrm{CO}_{2}$-emissie, energie-efficiëntie, duurzame energie, warmtekrachtkoppeling, inkoop warmte, elektriciteit, areaal, intensivering, extensivering, energiebesparing, glastuinbouw

Dit rapport is gratis te downloaden op https://doi.org/10.18174/533541 of op www.wur. nl/economicresearch (onder Wageningen Economic Research publicaties).

(C) 2020 Wageningen Economic Research

Postbus 29703, 2502 LS Den Haag, T 07033583 30, E communications.ssg@wur.nl, www.wur.nl/economic-research. Wageningen Economic Research is onderdeel van Wageningen University \& Research.

\section{(cc) BY-NC}

Dit werk valt onder een Creative Commons Naamsvermelding-Niet Commercieel 4.0 Internationaallicentie.

(C) Wageningen Economic Research, onderdeel van Stichting Wageningen Research, 2020 De gebruiker mag het werk kopiëren, verspreiden en doorgeven en afgeleide werken maken. Materiaal van derden waarvan in het werk gebruik is gemaakt en waarop intellectuele eigendomsrechten berusten, mogen niet zonder voorafgaande toestemming van derden gebruikt worden. De gebruiker dient bij het werk de door de maker of de licentiegever aangegeven naam te vermelden, maar niet zodanig dat de indruk gewekt wordt dat zij daarmee instemmen met het werk van de gebruiker of het gebruik van het werk. De gebruiker mag het werk niet voor commerciële doeleinden gebruiken.

Wageningen Economic Research aanvaardt geen aansprakelijkheid voor eventuele schade voortvloeiend uit het gebruik van de resultaten van dit onderzoek of de toepassing van de adviezen.

Wageningen Economic Research is ISO 9001:2015 gecertificeerd.

Wageningen Economic Research Rapport 2020-109 | Projectcode 2282200536

Foto omslag: Paul Bradbury/iStock 


\section{Inhoud}

$\begin{array}{ll}\text { Woord vooraf } & 5\end{array}$

$\begin{array}{ll}\text { Samenvatting } & 7\end{array}$

S.1 $\mathrm{CO}_{2}$-emissie glastuinbouw in 2019 hoger $\quad 7$

$\begin{array}{lll}\text { S.2 Overige uitkomsten } & 7\end{array}$

$\begin{array}{ll}\text { S.3 Methode } & 9\end{array}$

$\begin{array}{ll}\text { Summary } & 10\end{array}$

S.1 $\mathrm{CO}_{2}$ emissions from greenhouse horticulture increased in $2019 \quad 10$

S.2 Other outcomes 11

S.3 Method 13

1

Inleiding

$1.1 \quad$ Beleidsmatige context 14

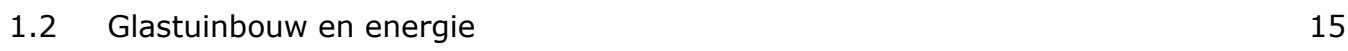

$\begin{array}{lll}1.3 & \text { De Energiemonitor } & 16\end{array}$

2

$\begin{array}{ll}\text { Energie-indicatoren op sectorniveau } & 17\end{array}$

$\begin{array}{lll}2.1 & \text { Inleiding } & 17\end{array}$

$\begin{array}{lll}2.2 \mathrm{CO}_{2} \text {-emissie } & 17\end{array}$

$\begin{array}{lll}2.3 & \text { Energie-efficiëntie } & 20\end{array}$

2.4 Aandeel duurzame energie $\quad 22$

2.5 Kwantitatieve analyse ontwikkeling $\mathrm{CO}_{2}$-emissie $\quad 23$

$\begin{array}{lll}2.6 & \text { Energiekosten } & 25\end{array}$

$\begin{array}{lll}2.7 & \text { Warmte- en elektriciteitsgebruik } & 27\end{array}$

$\begin{array}{lll}2.8 & \text { Energievoorziening zonder } \mathrm{CO}_{2} \text {-emissie } & 28\end{array}$

$3 \quad$ Analyse duurzame energie $\quad 30$

$\begin{array}{lll}3.1 & \text { Inleiding } & 30\end{array}$

$\begin{array}{lll}3.2 & \text { Bronnen van duurzame energie } & 30\end{array}$

3.2.1 Toepassing 30

$\begin{array}{ll}3.2 .2 & \text { Ontwikkeling per bron }\end{array}$

3.2.3 Productie, inkoop, verkoop en consumptie $\quad 35$

3.2.4 Bedrijfsstructuur $\quad 36$

$\begin{array}{lll}3.3 \mathrm{CO}_{2} \text {-emissiereductie } & 38\end{array}$

$\begin{array}{lll}3.4 & \text { Warmtedekking } & 39\end{array}$

$\begin{array}{lll}3.5 & \text { Inkoop } \mathrm{CO}_{2} & 41\end{array}$

4 Analyse wkk, inkoop van warmte en elektriciteitsbalans 44

$\begin{array}{lll}4.1 & \text { Inleiding } & 42\end{array}$

$\begin{array}{lll}4.2 & \text { Wkk glastuinbouwbedrijven } & 42\end{array}$

4.3 Inkoop van warmte $\quad 44$

$\begin{array}{lll}4.4 & \text { Reductie } \mathrm{CO}_{2} \text {-emissie } & 45\end{array}$

$\begin{array}{lll}4.5 & \text { Elektriciteitsbalans } & 46\end{array}$

$\begin{array}{llr}5 & \text { Reflectie } & 49\end{array}$

$\begin{array}{llr}6 & 54\end{array}$

$\begin{array}{ll}\text { Literatuur en websites } & 56\end{array}$ 
Bijlage 2 Kenmerken en energie-indicatoren glastuinbouw

Bijlage 3 Energiegebruik glastuinbouw (totale glastuinbouwareaal en niet gecorrigeerd voor temperatuur)

Bijlage 4 Gebruik en reductie $\mathrm{CO}_{2}$-emissie per duurzame energiebron en inkoop $\mathrm{CO}_{2}$

63

Bijlage 5 Gebruik en reductie $\mathrm{CO}_{2}$-emissie wkk en inkoop van warmte 


\section{Woord vooraf}

Voor de Nederlandse glastuinbouw is energie een belangrijk productiemiddel. Energie geproduceerd met fossiele brandstof brengt $\mathrm{CO}_{2}$-emissie met zich mee en dat versterkt het broeikaseffect. Tussen de glastuinbouw en de overheid is in de Meerjarenafspraak Energietransitie Glastuinbouw 2014-2020 een $\mathrm{CO}_{2}$-doelstelling voor 2020 voor de glastuinbouw overeengekomen. Hiermee is reductie van de $\mathrm{CO}_{2}$-emissie centraal komen te staan in het energiebeleid van de glastuinbouw. In het programma Kas als Energiebron werken Glastuinbouw Nederland en het ministerie van Landbouw, Natuur en Voedselkwaliteit (LNV) samen om de $\mathrm{CO}_{2}$-doelstelling te realiseren.

De oorspronkelijke $\mathrm{CO}_{2}$-doelstelling voor 2020 in de Meerjarenafspraak was 6,2 Mton. In 2017 werd de doelstelling technisch gecorrigeerd naar 4,6 Mton. Hiernaast is in het Klimaatakkoord een ambitie opgenomen van een glastuinbouw zonder $\mathrm{CO}_{2}$-emissie in 2040. Ook Glastuinbouw Nederland heeft deze ambitie uitgesproken. Uit de ontwikkelde scenario's voor de glastuinbouw door Wageningen Economic Research in 2017 resulteerden Prognoses voor de $\mathrm{CO}_{2}$-emissie in 2030 in de range van 2,7 tot 3,3 Mton. In het Klimaatakkoord is voor de glastuinbouw een ambitie opgenomen van een maximale uitstoot van 2,2 Mton in 2030 op basis van de benodigde afspraken en randvoorwaarden in het Klimaatakkoord.

De ambities omvatten substantiële reducties van de $\mathrm{CO}_{2}$-emissie van de glastuinbouw waarvoor een transitie nodig is. Vermindering van het energiegebruik per $\mathrm{m}^{2}$ en van het gebruik van wkk op aardgas in combinatie met groei van het gebruik van duurzame energie, inkoop van warmte, inkoop elektriciteit en externe $\mathrm{CO}_{2}$ is hiervoor noodzakelijk. Voor deze transitie zijn in deze monitor belangrijke beleidsmatige knelpunten geïdentificeerd op het terrein het fiscaal regime, het stimuleringskader, de infrastructuur en de kennisontwikkeling. De convenantpartners staan hierbij voor onder meer de keuze om het gebruik van aardgas-wkk's de komende jaren te continueren of juist af te remmen.

Om realistische keuzes te kunnen maken, is het voor beleid en belangenbehartiging belangrijk de werkelijke ontwikkelingen met hun achtergronden in beeld te hebben. De Energiemonitor van de Nederlandse Glastuinbouw kwantificeert en analyseert de ontwikkeling van het energiegebruik en bijbehorende energie-indicatoren. Een belangrijk element bij de ontwikkeling van de indicatoren $\mathrm{CO}_{2}-$ emissie en energie-efficiëntie is de ontwikkeling van het areaal. Op basis van de Landbouwtelling (LBT) van het Centraal Bureau van de Statistiek nam het areaal in 2019 met zo'n 700 ha (8\%) toe. Vanuit de beschikbare inzichten was dit maar voor een deel het resultaat van nieuwbouw en sloop van kassen. In 2019 hebben meer bedrijven de LBT ingevuld waardoor het gerapporteerde areaal groter is. Het is aannemelijk dat de LBT in 2019 dichter bij de werkelijke situatie zit maar voor eerdere jaren een te laag areaal geeft.

In het convenant is afgesproken dat als de $\mathrm{CO}_{2}$-emissie door wijziging van de externe factoren areaal en verkoop elektriciteit buiten een bandbreedte komt te liggen, het $\mathrm{CO}_{2}$-doel kan worden aangepast. Op basis van de verwachtingen in 2016 is in 2017 een technische correctie met een verlaging van het $\mathrm{CO}_{2}$-doel overeengekomen. De actuele verwachting voor 2020 is echter dat het areaal en de verkoop van elektriciteit groter zullen zijn. Door Wageningen Economic Research is voortbouwend op de voorliggende Energiemonitor 2019 een raming van de $\mathrm{CO}_{2}$-emissie 2020 gemaakt. Hieruit blijkt dat de $\mathrm{CO}_{2}$-emissie in 2020 niet veel zal wijzigen ten opzichte van 2019 en dat door toename van het areaal en verkoop elektriciteit de $\mathrm{CO}_{2}$-emissie in 2020 buiten de bandbreedte komt te liggen. Dit betekent dat de convenantspartijen kunnen besluiten om een nieuwe technische correctie door te voeren met een grotere $\mathrm{CO}_{2}$-emissieruimte in 2020. Dit betekent ook dat er nog geen uitspraak kan worden gedaan over het realiseren van het doel voor 2020 . 
Wageningen Economic Research maakt jaarlijks de Energiemonitor Glastuinbouw in opdracht van de Stichting Kennis in je Kas van de glastuinbouwsector en met subsidie van het ministerie van LNV in het kader van KaE. De Energiemonitor 2019 is de 30e editie. De begeleidingscommissie bestond uit Piet Broekharst (Glastuinbouw Nederland), John van Himbergen (LNV) en Olaf Hietbrink (Wageningen Economic Research). Vele partijen hebben informatie aangeleverd, waarvan dankbaar gebruik is gemaakt.

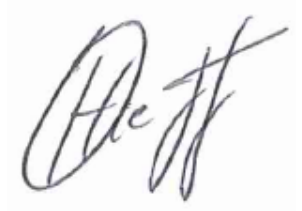

Ir. O. (Olaf) Hietbrink

Business Unit Manager Wageningen Economic Research

Wageningen University \& Research 


\section{Samenvatting}

\section{S.1 $\mathrm{CO}_{2}$-emissie glastuinbouw in 2019 hoger}

De $\mathrm{CO}_{2}$-emissie van de Nederlandse glastuinbouw is in 2019 met 0,2 Mton toegenomen. Daarmee ligt de $\mathrm{CO}_{2}$-emissie 1,3 Mton boven het actuele doel voor 2020 (4,6 Mton), maar 0,3 Mton onder het doel voor de technische correctie uit 2017 (6,2 Mton). De $\mathrm{CO}_{2}$-emissie lag in $201914 \%$ onder het niveau van 1990. In geheel Nederland was de $\mathrm{CO}_{2}$-emissie in 2019 4\% lager dan in 1990.

De toename van de $\mathrm{CO}_{2}$-emissie in 2019 volgt vooral uit de toename van het areaal van de Landbouwtelling. Dit komt niet overeen met het saldo van nieuwbouw en sloop. In 2019 hebben meer bedrijven de LBT ingevuld waardoor het gerapporteerde areaal groter is. Het is aannemelijk dat de LBT in 2019 dichter bij de werkelijke situatie zit, maar voor eerdere jaren een te laag areaal geeft.

Hiernaast groeide de $\mathrm{CO}_{2}$-emissie in 2019 ook door toename van de verkoop van elektriciteit en afname van de inkoop van niet-duurzame warmte. Deze effecten werden deels gedempt door de groei bij het gebruik van duurzame energie en bij inkoop elektriciteit.

In de periode 2014-2018 was de $\mathrm{CO}_{2}$-emissie min of meer stabiel. In deze periode nam de $\mathrm{CO}_{2}$ emissie aan de ene kant toe door groei van het energiegebruik per $\mathrm{m}^{2}$ en de verkoop van elektriciteit en aan de andere kant af door krimp van het areaal, toename van duurzame energie en van inkoop elektriciteit.

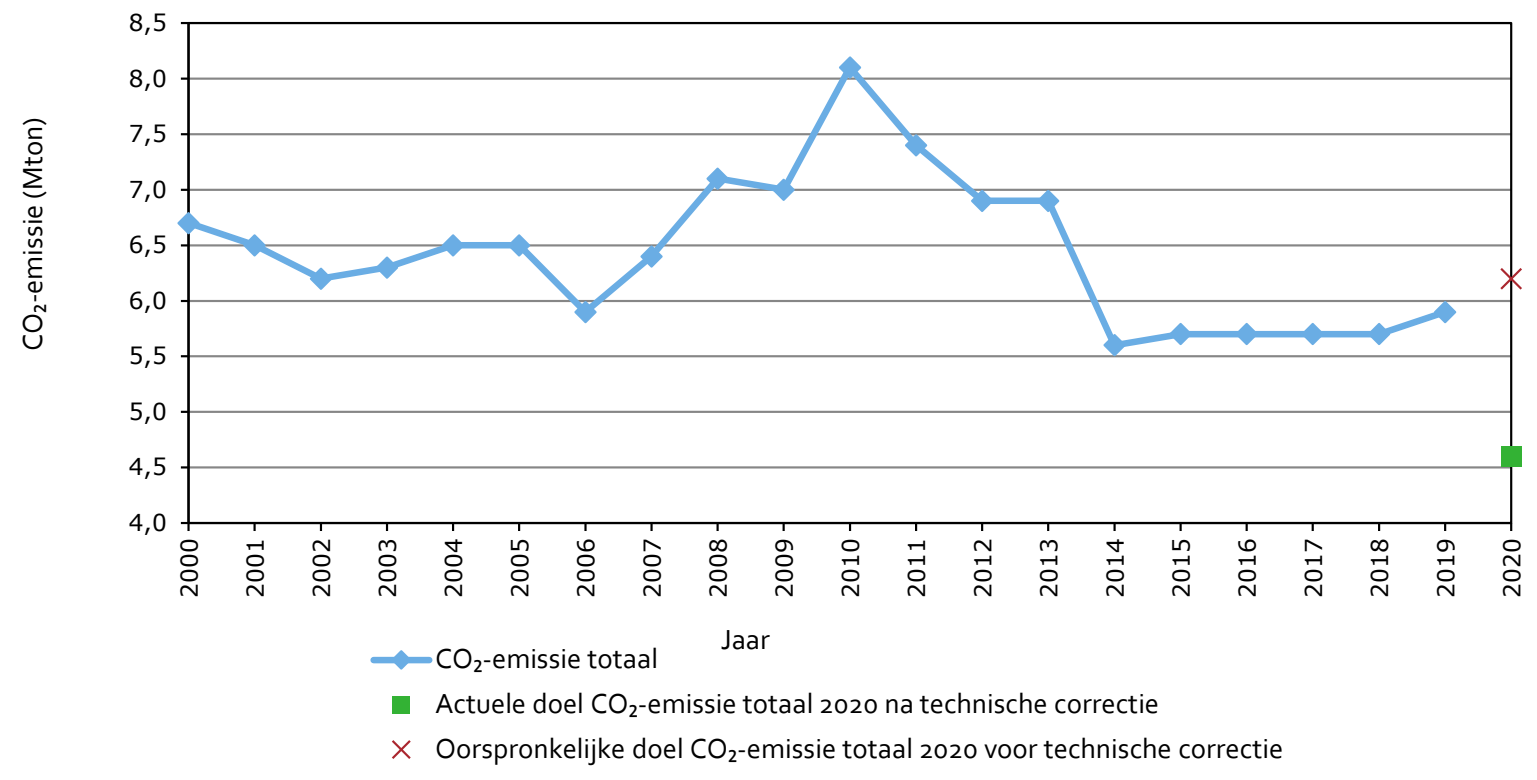

Figuur S.1 $\mathrm{CO}_{2}$-emissie van de Nederlandse glastuinbouw per jaar en het doel voor 2020 a) a) Cijfers 2019 voorlopig.

\section{S.2 Overige uitkomsten}

Duurzame energie groeit sterk

Het gebruik van duurzame energie is in 2019 sterk toegenomen. Het gebruik nam met 35\% toe tot 10,0 PJ. Het aandeel in het totaal energiegebruik groeide van 7,4 naar 9,4\%. Niet eerder was er zo'n sterke toename van het gebruik van duurzame energie in de glastuinbouw. De groei zat vooral bij 
inkoop van duurzame warmte. De exploitatie van nieuwe duurzame energie projecten is vaker in handen van externe partijen en dan koopt de glastuinbouw duurzame warmte in. Hiernaast namen ook het gebruik van biobrandstof en van aardwarmte toe. In 2019 was aardwarmte de meest toegepaste duurzame energiebron, op afstand gevolgd door inkoop duurzame warmte, inkoop duurzame elektriciteit, biobrandstoffen en zonne-energie.

Voor Nederland als geheel bedroeg het aandeel duurzame energie in 2019 8,7\%. Het aandeel in de glastuinbouw komt daarmee in 2019 voor het eerst hoger uit dan het landelijk aandeel. Het gebruik van duurzame energie bestond voor $87 \%$ uit warmte en $13 \%$ uit elektriciteit. De duurzame warmte werd voor $71 \%$ zelf geproduceerd en de elektriciteit voor $97 \%$ ingekocht. Het areaal met duurzame energie (exclusief inkoop uit openbare netten) nam in 2019 toe naar ruim 2.100 ha. Dit is $22 \%$ van het totaal areaal. Het gebruik van duurzame energie heeft in 2019 een positief effect op de $\mathrm{CO}_{2}$ emissie van de glastuinbouw van 0,5 Mton.

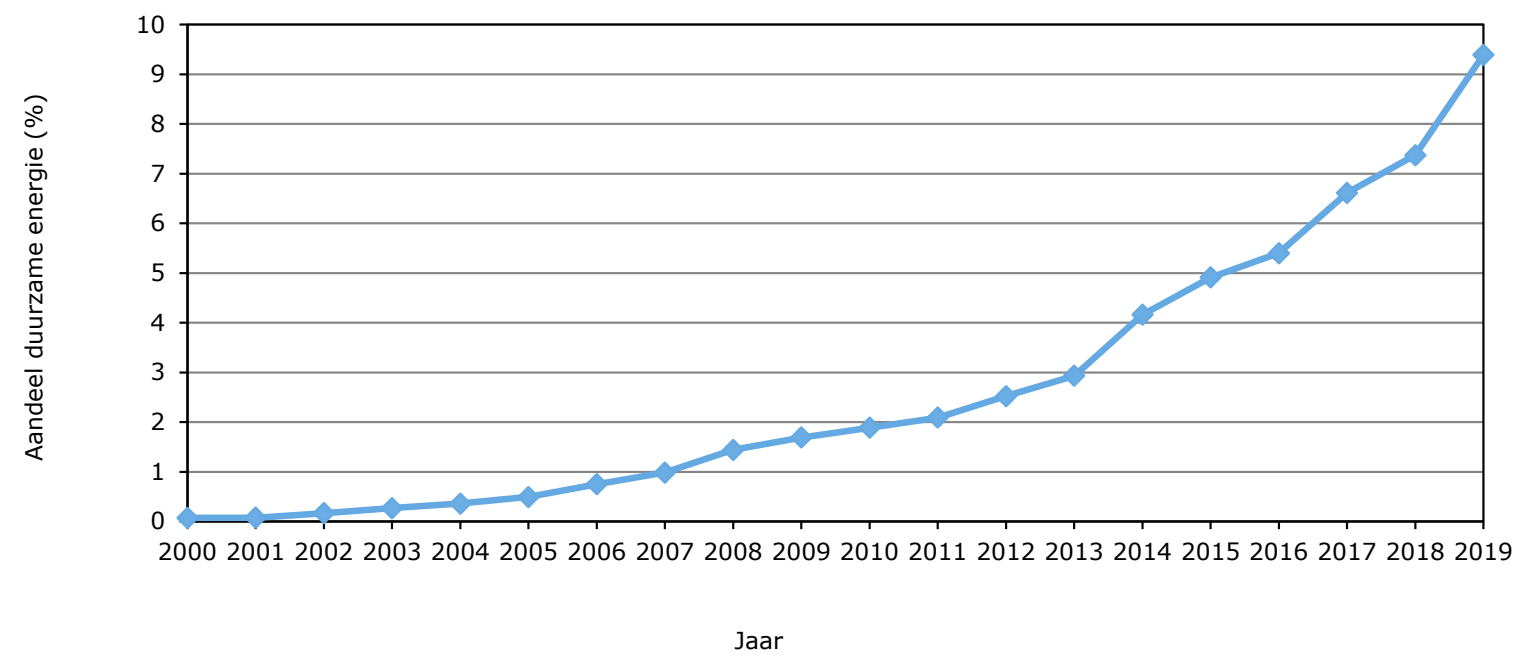

Figuur S.2 Aandeel duurzame energie in de Nederlandse glastuinbouw per jaar a) a) Cijfers 2019 voorlopig.

Energievoorziening zonder $\mathrm{CO}_{2}$-emissie en inkoop $\mathrm{CO}_{2}$ groeien Het aandeel van aardgas in de energievoorziening van de glastuinbouw daalde in de periode 20102019 van $88 \%$ naar 78\%. Deze ontwikkeling komt vooral door de groei van duurzame energie en in minder mate door de groei van inkoop elektriciteit. De vermindering van inkoop niet-duurzame warmte had een negatieve invloed. Het gebruik van externe $\mathrm{CO}_{2}$ door de glastuinbouw groeide in 2019 door met bijna $5 \%$ tot 0,7 Mton.

\section{Energie-efficiëntie met 1 procentpunt verslechterd}

De energie-efficiëntie ofwel het primair brandstofverbruik per eenheid product is in 2019 met 1 procentpunt verslechterd tot $45 \%$ ten opzichte van 1990. Dit kwam doordat de fysieke productie per $\mathrm{m}^{2}(-7 \%)$ sterker daalde dan het primair brandstofverbruik per $\mathrm{m}^{2}(-3 \%)$. De vermindering van het primair brandstofverbruik kwam vooral door de toename van het gebruik van duurzame energie. De daling van de fysieke productie hing vooral samen met de toename van het areaal.

Over een langere periode bezien is de energie-efficiëntie vanaf 2010 tot 2018 min of meer stabiel. De afvlakking vanaf 2010 komt mede door het streven naar een hogere waarde van de glastuinbouwproducten en door productie in de winterperiode met belichting oftewel een verschuiving van kwantiteit naar kwaliteit. De eerste ontwikkeling remt de ontwikkeling van de fysieke productie en de tweede doet het primair brandstofverbruik toenemen.

\section{Energiegebruik}

Het totaal energiegebruik nam in 2019 toe tot 106,8 PJ en bestond voor circa $74 \%$ uit warmte en voor de resterende $26 \%$ uit elektriciteit waar dit in 2010 nog $90 \%$ en $10 \%$ was. Er trad dus een 
verschuiving op van warmte naar elektriciteit. Deze verschuiving komt hoofdzakelijk door de toename van groeilicht. De consumptie van elektriciteit neemt al jaren toe en bedroeg in 2019 circa 8 miljard kWh. Dit is $6 \%$ van de nationale consumptie. In de elektriciteitsvraag werd voor $58 \%$ voorzien door productie met vrijwel alleen wkk's en de resterende $42 \%$ werd ingekocht. Ook de inkoop is vanaf 2014 gestegen naar 3,3 miljard kWh in 2019.

\section{Energiekosten en warmtekrachtkoppeling}

De kosten voor inkoop van energie namen in 2019 sterker af dan de opbrengsten voor de verkoop. Hierdoor namen de netto-energiekosten $\left(€ / \mathrm{m}^{2}\right)$ af. De kosten voor zowel inkoop aardgas als voor inkoop en verkoop elektriciteit daalden. De daling bij elektriciteit was echter minder sterk dan bij aardgas. Hierdoor verbeterde de spark spread en werd het aantrekkelijker wkk in te zetten voor zowel de eigen consumptie als de verkoop van elektriciteit. Dit leidde ertoe dat de gemiddelde gebruiksduur in 2019 groeide naar circa 4.100 uur. Hierdoor nam de elektriciteitsproductie in 2019 toe naar circa 10,5 miljard kWh. Dit is $9 \%$ van de nationale consumptie. Niet eerder werd er zoveel elektriciteit geproduceerd door de glastuinbouw. De productie werd voor circa 56\% verkocht en de resterende $44 \%$ werd door de glastuinbouw zelf gebruikt. In 2019 bedroeg het totaal vermogen van de wkk's circa $2.550 \mathrm{MW}_{\mathrm{e}}$ en op circa $62 \%$ van het areaal is wkk in gebruik.

Door het gebruik van aardgas-wkk's lag in 2019 de $\mathrm{CO}_{2}$-emissie van de glastuinbouw 1,6 Mton hoger en van elektriciteitscentrales 2,5 Mton lager. Op nationaal niveau werd zo 0,9 Mton $\mathrm{CO}_{2}$-emissie vermeden. Dit komt niet tot uiting in de $\mathrm{CO}_{2}$-emissie van de glastuinbouw, omdat bij de IPCCmethode de $\mathrm{CO}_{2}$-emissie wordt toebedeeld aan de energieproducent en niet aan de gebruiker.

\section{Knelpunten verdere reductie $\mathrm{CO}_{2}$-emissie}

Voor verdere reductie van de $\mathrm{CO}_{2}$-emissie van de glastuinbouw zijn de volgende beleidsmatige knelpunten geïdentificeerd:

- Het gebruik van de energievoorzieningsopties zonder $\mathrm{CO}_{2}$-emissie, duurzame warmte, inkoop van warmte en inkoop elektriciteit wordt belemmerd door het actueel gunstige bedrijfseconomisch perspectief voor wkk, maar ook door de kostenstijging door de verhoging van ODE op elektriciteit.

- De warmtedekking door duurzame warmte is relatief laag en neemt de laatste jaren af, terwijl het totaal gebruik van duurzame warmte groeit. Dit komt door de relatief kleine capaciteit per $\mathrm{m}^{2}$ kas, wat vooral veroorzaakt wordt door de structuur van de SDE en het spreiden van projectrisico's door externe partners en tuinders. Hierdoor zal het gebruik van duurzame warmte op termijn tegen grenzen aanlopen: 'Het laaghangend fruit is dan geplukt.'

- Voor toename van het gebruik van de energievoorzieningsopties zonder $\mathrm{CO}_{2}$-emissie is infrastructuur voor warmte, elektriciteit en externe $\mathrm{CO}_{2}$ nodig met voldoende capaciteit op regionaal niveau. Een toegesneden stimuleringskader is hierbij van groot belang.

- Het realiseren van warmtebesparing door bijvoorbeeld HNT wordt op bedrijven met belichting geremd door de ODE op elektriciteit. Bovendien zijn er specifieke technische kennisvragen en teeltkundige kennisvragen op gewasniveau.

\section{S.3 Methode}

In de Energiemonitor glastuinbouw worden jaarlijks de energie-indicatoren $\mathrm{CO}_{2}$-emissie, energieefficiëntie en aandeel duurzame energie in de glastuinbouw gekwantificeerd. Hiervoor worden de energiebalans en de fysieke productie in kaart gebracht en samen met de indicatoren geanalyseerd en geduid in de context van de ontwikkelingen. Voor deze activiteiten is een methodiek ontwikkeld waarin sectordeskundigen een reeks van informatiebronnen combineren. De methodiek is vastgelegd in een protocol dat naast de Energiemonitor wordt gepubliceerd. 


\section{Summary}

\section{S.1 $\mathrm{CO}_{2}$ emissions from greenhouse horticulture increased in 2019}

The $\mathrm{CO}_{2}$ emissions of Dutch greenhouse horticulture have increased by 0.2 Mton in 2019. $\mathrm{CO}_{2}$ emissions were therefore 1.3 Mton above the current target for 2020 (4.6 Mton), but 0.3 Mton below the target before the technical correction of 2017 (6.2 Mton). In $2019 \mathrm{CO}_{2}$ emissions were $14 \%$ below the level of 1990. For the Netherlands as a whole, $\mathrm{CO}_{2}$ emissions were 4\% lower in 2019 than in 1990.

The increase of $\mathrm{CO}_{2}$ emissions in 2019 were mainly the result of increased acreage reported in the Agricultural Census (LBT). This does not correspond to the net difference between new construction and demolition. In 2019 more agricultural operations did participate in the LBT; as a result, the reported acreage was larger. It is likely that the LBT for 2019 reflects the actual situation more accurately and that the reported acreage for previous years was too low.

The increase of $\mathrm{CO}_{2}$ emissions 2019 were also due to increased sales of electricity and decreased purchases of non-sustainable heat. These effects were partially subdued by growth in the use of renewable energy and purchase of electricity.

In the period between 2014 and $2018, \mathrm{CO}_{2}$ emissions were essentially stable. During this period $\mathrm{CO}_{2}$ emissions increased on the one hand due to growth in energy consumption per $\mathrm{m}^{2}$ and increased sales of electricity and on the other hand they decreased due to shrinkage of acreage, increased use of renewable energy and more purchase of electricity.

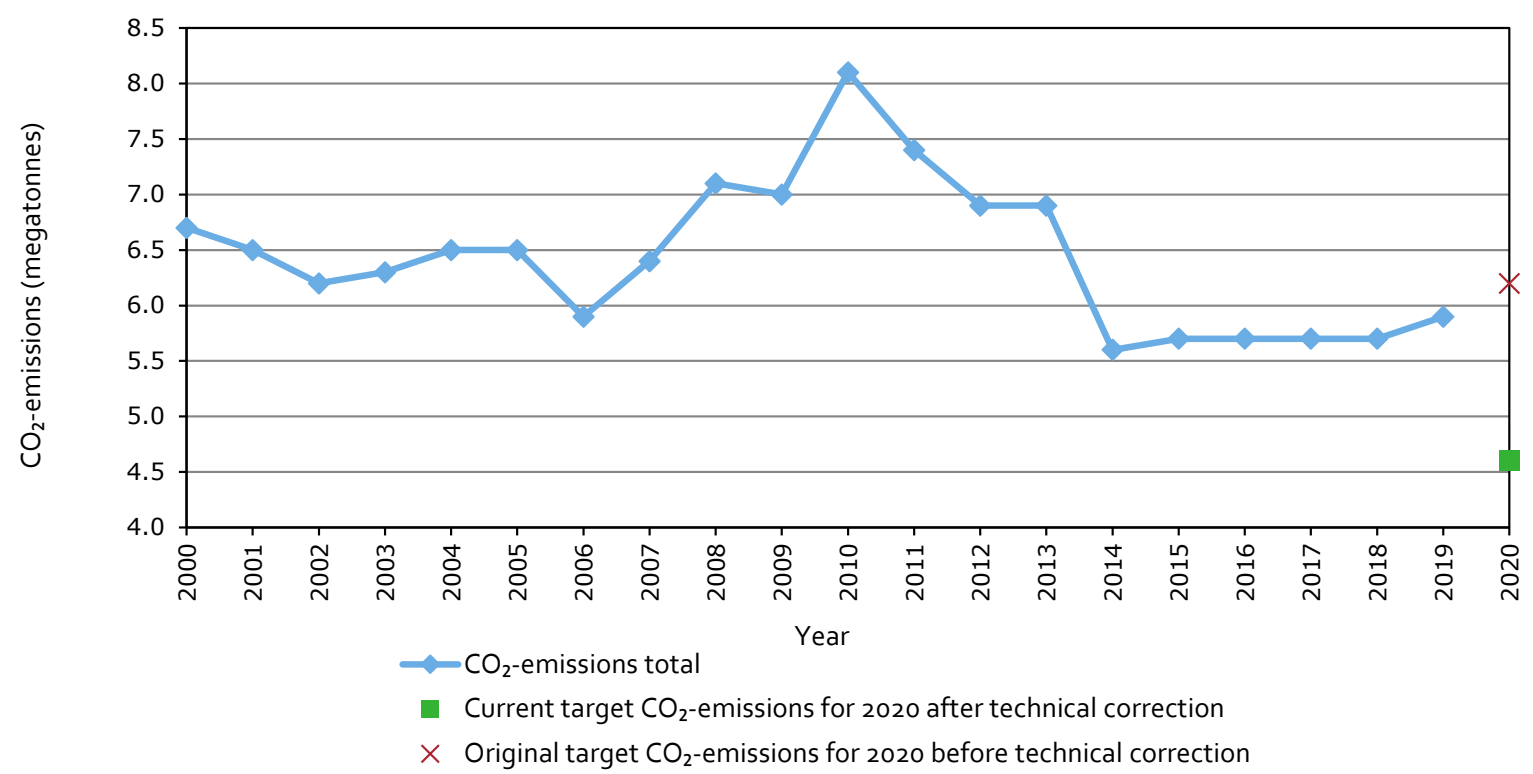

Figure S.1 CO $\mathrm{CO}_{2}$ emissions of Dutch greenhouse horticulture per year and the target for 2020 a) a) Results for 2019 are provisional. 


\section{S.2 Other outcomes}

Renewable energy is growing sharply

The use of renewable energy has increased substantially in 2019 . Usage increased by $35 \%$ to $10.0 \mathrm{PJ}$. The share in total energy consumption grew from $7.4 \%$ to $9.4 \%$. Never before had there been such a strong increase in the use of sustainable energy in greenhouse horticulture. The purchase of sustainable heat showed the largest growth. The exploitation of new sustainable energy projects is more often done by external parties. In those situations greenhouse companies purchase the sustainable heat. The use of biofuels and geothermal energy also increased. In 2019 geothermal energy was the most commonly used renewable energy source, followed at a distance by purchasing sustainable heat and sustainable electricity, biofuels and solar energy.

For the Netherlands as a whole, the share of renewable energy in 2019 was $8.7 \%$. For the first time in 2019 the share of renewable energy in greenhouse horticulture will therefore be higher than the national share. Of sustainable energy consumption $87 \%$ consisted of heat and $13 \%$ of electricity. Of these totals $71 \%$ of the heat was self-produced, and $97 \%$ of the electricity was purchased from external parties. The greenhouse acreage using sustainable energy (excluding purchase from public grids) increased to over 2,100 ha in 2019 . This is $22 \%$ of the total acreage. In 2019 the use of sustainable energy had a positive effect on the $\mathrm{CO}_{2}$ emissions of Dutch greenhouse horticulture of 0.5 Mton.

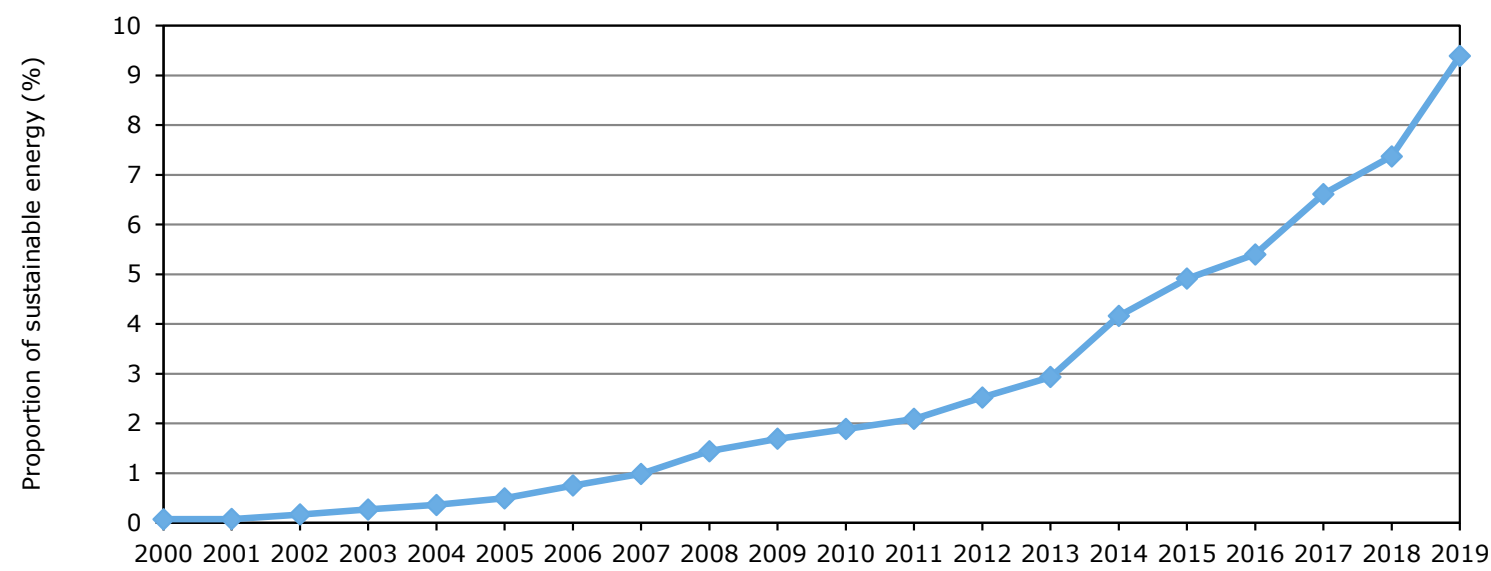

Year

Figure S.2 Share of sustainable energy in Dutch greenhouse horticulture per year a) a) Data for 2019 are provisional.

Growth in $\mathrm{CO}_{2}$ emission-free energy sources and purchasing $\mathrm{CO}_{2}$

Between 2010 and 2019 the share of natural gas in the energy supply of greenhouse horticulture decreased from $88 \%$ to $78 \%$. This development was mainly due to the growth in renewable energy sources and to a lesser extent because of the growth in electricity purchase. The decrease of nonsustainable heat purchase had a negative effect. The use of external $\mathrm{CO}_{2}$ sources in greenhouse horticulture continued to grow in 2019 by almost 5\% to 0.7 Mton.

\section{Energy efficiency decreased by 1 percent}

Compared to 1990 energy efficiency (defined as primary fuel consumption per unit of product) dropped by 1 percent in 2019 to $45 \%$. This was because the decrease of physical production per $\mathrm{m}^{2}$ $(-7 \%)$ was greater than the decrease of primary fuel consumption per $m^{2}(-3 \%)$. The decrease of primary fuel consumption was mainly due to increased use of renewable energy. The decline in physical production per $\mathrm{m}^{2}$ corresponded primarily with the increased acreage. 
Viewed over a longer period, energy efficiency was essentially stable from 2010 to 2018 . The levelling from 2010 was partly due to the strategy to produce higher-value products in greenhouse horticulture and partly due to production in the winter period using artificial lighting, essentially a shift in emphasis from quantity to quality. The shift to higher-valued products slowed efficiency gains in physical production and the shift to production with artificial lighting increased primary fuel consumption.

\section{Energy consumption}

Total energy consumption increased in 2019 to $106.8 \mathrm{PJ}$; approximately $74 \%$ of this total consisted of heat and $26 \%$ of electricity, compared to $90 \%$ and $10 \%$ in 2010 . Essentially there was a shift from heat to electricity, which was mainly due to the increased use of artificial lighting. Electricity consumption has been increasing for years and totalled approximately 8 billion kWh in 2019. This amounts to $6 \%$ of Dutch national consumption. About $58 \%$ of this electricity was self-produced by cogeneration of heat and power and the remaining $42 \%$ was purchased. Also the amount of purchased electricity has steadily increased since 2014 to 3.3 billion kWh in 2019 .

\section{Energy costs and co-generation of heat and power (CHP)}

The costs for the purchase of energy dropped more sharply in 2019 than the energy-sale revenues. As a result the net energy costs $\left(€ / \mathrm{m}^{2}\right)$ decreased. Commodity prices for natural gas as well as electricity also decreased. However, the decrease of electricity-prices was less sharp compared to natural gas. This improved the spark spread and made it more attractive to use CHP for both self-use and sale of electricity. As a result average CHP use increased to approximately 4,100 hours in 2019 and total electricity production increased to approximately 10.5 billion kWh. This amounts to $9 \%$ of Dutch national electricity consumption. Never before has so much electricity been produced by greenhouse horticulture. About $56 \%$ of the production was sold and the remaining $44 \%$ was self-used for greenhouse operation. In 2019 total CHP capacity was approximately 2,550 $\mathrm{MW}_{\mathrm{e}}$ and $\mathrm{CHP}$ was used on about $62 \%$ of the acreage.

Due to the use of natural-gas-fuelled $\mathrm{CHP}$, in $2019 \mathrm{CO}_{2}$ emissions from greenhouse horticulture were 1.6 Mton higher and 2.5 Mton lower from power stations. At the national level, $0.9 \mathrm{Mton}$ of $\mathrm{CO}_{2}$ emissions were thus avoided. This was not reflected in decreased $\mathrm{CO}_{2}$ emissions from greenhouse horticulture because the IPCC method allocates the $\mathrm{CO}_{2}$ emissions to the energy producer, not to the energy user.

\section{Constraints for further reduction of $\mathrm{CO}_{2}$ emissions}

The following policy constraints have been identified for further reduction of $\mathrm{CO}_{2}$ emissions from greenhouse horticulture:

- The use of energy-sources without $\mathrm{CO}_{2}$-emissions, sustainable heat, purchase of heat and purchase of electricity is hampered not only by the currently favourable economic prospects for $\mathrm{CHP}$, but also by the increased cost of electricity due to the rise of charges of energy and climate transition surcharge; ODE.

- The heat coverage of sustainable heat is relatively low and has decreased in recent years, while the total use of sustainable heat has grown. This is due to the relatively small capacity per $\mathrm{m}^{2}$ of greenhouse area, which is mainly caused by the structure of the incentives of government support for sustainable energy production (SDE) and the spreading of project risks by both external partners and growers. As a result the total use of sustainable heat will be constrained in the long term.

- Increased use energy sources without $\mathrm{CO}_{2}$-emissions requires regional infrastructure for heat, electricity and external $\mathrm{CO}_{2}$ with sufficient capacity. A tailor-made incentive framework is of great importance in this respect.

- The realisation of heat savings (for example through innovative energy-efficient strategies for greenhouse climate control; HNT) is hampered for greenhouse operations with artificial lighting due to the surcharge (ODE) on electricity. Moreover specific issues about technical expertise and cultivation expertise at the crop level must still be resolved. 


\section{S.3 Method}

The Energy Monitor for Dutch greenhouse horticulture annually quantifies the energy indicators $\mathrm{CO}_{2}$ emission, energy efficiency and the proportion of sustainable energy in greenhouse horticulture. To this the energy balance and physical production are surveyed and analysed together with the indicators and interpreted in the context of the corresponding developments. A method has been developed for these activities in which sector experts combine a range of information sources. The method is laid down in a protocol that is published in parallel with the Energy Monitor. 


\section{$1 \quad$ Inleiding}

\subsection{Beleidsmatige context}

\section{Meerjarenafspraak Energietransitie Glastuinbouw}

Tussen de Nederlandse glastuinbouw en de Nederlandse overheid is in 2014 de Meerjarenafspraak Energietransitie Glastuinbouw 2014-2020 gemaakt. Deze afspraak bouwt voort op het Convenant $\mathrm{CO}_{2}$-emissieruimte binnen het $\mathrm{CO}_{2}$-sectorsysteem glastuinbouw. In beide convenanten staat de $\mathrm{CO}_{2}$-emissie centraal. Het doel in de Meerjarenafspraak is een maximale $\mathrm{CO}_{2}$-emissie van 6,2 Mton in 2020 en is een onderdeel van de Nederlandse taakstelling voor het Europese doel om in $202020 \%$ minder $\mathrm{CO}_{2}$ uit te stoten in vergelijking met 1990.

\section{Technische correctie}

De $\mathrm{CO}_{2}$-emissie van de glastuinbouw daalde in de periode 2010-2015 sterk (Van der Velden en Smit, 2017b) en de prognose van de $\mathrm{CO}_{2}$-emissie in 2020 voorzag een verdere daling (Van der Velden en Smit, 2016). Deze voorziene daling van de $\mathrm{CO}_{2}$-emissie kwam voor een belangrijk deel door krimp van het areaal en minder verkoop van elektriciteit vanuit warmtekrachtkoppeling (wkk). Deze ontwikkelingen waren geen resultaat van inspanning door de glastuinbouw maar van ontwikkelingen op de markt van tuinbouwproducten en de energiemarkt. De convenantspartijen hebben daarom, volgens de afspraken in het convenant, besloten om de $\mathrm{CO}_{2}$-emissieruimte c.q. het $\mathrm{CO}_{2}$-doel voor de glastuinbouw in 2020 technisch te corrigeren (Brief, 2017) naar 4,6 Mton.

\section{Voorgaande convenanten}

In eerdere convenanten waren ook doelen opgenomen over de energie-efficiëntie, het aandeel duurzame energie, de $\mathrm{CO}_{2}$-emissie van de teelt en de reductie van de $\mathrm{CO}_{2}$-emissie door wkk. In de Meerjarenafspraak van 2014 zijn deze doelen weliswaar verlaten, maar het blijven elementen die van invloed zijn op de $\mathrm{CO}_{2}$-emissie. Het blijft daarom belangrijk om ook de ontwikkeling van deze indicatoren in beeld te brengen.

\section{Programma Kas als Energiebron}

Om het doel van de Meerjarenafspraak te bereiken, werken de glastuinbouw en de rijksoverheid samen in het programma Kas als Energiebron (KaE). Voor 2050 heeft KaE de ambitie dat de glastuinbouw een volledig duurzame en economisch rendabele energievoorziening zonder $\mathrm{CO}_{2}$-emissie heeft. De glastuinbouw heeft hiernaast zelf de ambitie uitgesproken om al in 2040 geen $\mathrm{CO}_{2}$ meer uit te stoten en deze ambitie staat ook in het Klimaatakkoord.

\section{$\mathrm{CO}_{2}$-emissie}

De $\mathrm{CO}_{2}$-emissie in de Meerjarenafspraak heeft betrekking op de absolute uitstoot van $\mathrm{CO}_{2}$. Deze wordt bepaald met de IPCC-methode (Intergovernmental Panel on Climate Change) en heeft alleen betrekking op het fossiele brandstofverbruik van de glastuinbouw op locatie. In- en verkoop van energie (elektriciteit en warmte) tellen hierom niet mee. In de Energiemonitor wordt bij de $\mathrm{CO}_{2}$-emissie, voor een beter begrip en duiding, onderscheid gemaakt tussen totale $\mathrm{CO}_{2}$-emissie en $\mathrm{CO}_{2}$-emissie van de teelt. Het verschil is de emissie die samenhangt met de verkoop van elektriciteit uit aardgasgestookte wkk. Het doel van de Meerjarenafspraak heeft betrekking op de totale $\mathrm{CO}_{2}$-emissie. De uitstoot van andere broeikasgassen valt buiten de Meerjarenafspraak en deze monitor.

\section{Energie-efficiëntie}

De energie-efficiëntie is een relatieve indicator, gedefinieerd als het primair brandstofverbruik per geproduceerde eenheid (tuinbouw)product. Het primair brandstofverbruik is de fossiele brandstof die nodig is voor de productie van de energie-input, verminderd met de fossiele brandstof die elders wordt uitgespaard door energie-output van de glastuinbouw. Bij het primair brandstofverbruik worden naast het verbruik van fossiele brandstof door de glastuinbouw dus ook de fossiele brandstof die nodig is voor de productie van de overige energie-input en -output in beschouwing genomen. Vervolgens 
wordt het primair brandstofverbruik uitgedrukt in de omvang van de fysieke tuinbouwproductie waarvoor de brandstof is ingezet.

\section{Aandeel duurzame energie}

Het aandeel duurzame energie is net als de energie-efficiëntie een relatieve indicator. Het is het gebruik van duurzame energie ten opzichte van het totale netto-energiegebruik van de glastuinbouw, uitgedrukt in procenten. Het totale netto-energiegebruik en de hoeveelheid duurzame energie worden bepaald op basis van de energie-inhoud van de energie-input en -output.

\section{Protocol}

De definities van de indicatoren, de methodiek en de gebruikte bronnen voor de monitor zijn vastgelegd in het Protocol Energiemonitor Glastuinbouw (Van der Velden en Smit, 2020a) en zijn in bijlage 1 op hoofdlijnen toegelicht. In het protocol wordt onderscheid gemaakt tussen de conceptuele methodiek en de werkwijze. De werkwijze kan in de loop der jaren wijzigen, onder andere door beschikbaarheid van databronnen en mutaties in omrekeningsfactoren. Hierdoor wordt jaarlijks een update van het Protocol gepubliceerd met mutaties en verbeteringen in de werkwijze.

\section{$\mathrm{CO}_{2}$-emissieruimte en $\mathrm{CO}_{2}$-sectorsysteem}

Naast de Meerjarenafspraak bestaat er voor de glastuinbouw een $\mathrm{CO}_{2}$-sectorsysteem. In het Convenant $\mathrm{CO}_{2}$-emissieruimte binnen het $\mathrm{CO}_{2}$-sectorsysteem glastuinbouw is een totale $\mathrm{CO}_{2}$-emissieruimte van 6,2 Mton in 2020 afgesproken (brief, 2017). Dit is inclusief de verkoop van elektriciteit. Ook deze $\mathrm{CO}_{2}$-emissieruimte voor 2020 is in 2017 technisch gecorrigeerd naar 4,6 Mton. In de jaren dat de $\mathrm{CO}_{2}$-emissie van de glastuinbouw boven de emissieruimte zit, wordt door de glastuinbouw de waarde van de emissie-overschrijding aan de overheid betaald. Deze kosten worden door de sector opgebracht middels het $\mathrm{CO}_{2}$-sectorsysteem. In dit systeem worden de kosten doorberekend aan de individuele bedrijven. Het $\mathrm{CO}_{2}$-sectorsysteem beoogt hiermee het $\mathrm{CO}_{2}$-doel van de glastuinbouw te borgen.

\subsection{Glastuinbouw en energie}

\section{Ontwikkeling $\mathrm{CO}_{2}$-emissie}

De jaarlijkse $\mathrm{CO}_{2}$-emissie van de glastuinbouw wordt praktisch bezien beïnvloed door zeven ${ }^{1}$ factoren (Van der Velden en Smit, 2017). Deze factoren zijn: de buitentemperatuur, het areaal kassen, ${ }^{2}$ verkoop elektriciteit, gebruik duurzame energie, inkoop van warmte, ${ }^{3}$ inkoop elektriciteit en de energievraag per $\mathrm{m}^{2}$. Achter de energievraag per $\mathrm{m}^{2}$ zitten de processen intensivering en extensivering van de teelt (toeen afname van de energievraag per $\mathrm{m}^{2}$ ) en energiebesparing (afname van de energievraag per $\mathrm{m}^{2}$ ).

\section{Areaal kassen}

De ontwikkeling van het areaal is vooral afhankelijk van de vraag naar de afzonderlijke Nederlandse glastuinbouwproducten, de productiekosten en de fysieke productie per $\mathrm{m}^{2}$ kas.

\section{Intensivering}

De energievraag verandert door intensivering en extensivering. Het gematigde klimaat in Nederland met relatief zachte winters en relatief koele zomers is gunstig voor de teelt van glastuinbouwproducten. De Nederlandse glastuinbouw kenmerkt zich door een relatief hoge fysieke productie en waarde maar ook relatief hoge kosten per $\mathrm{m}^{2}$ kas. Door internationale concurrentie is in de Nederlandse glastuinbouw een continu proces van intensivering gaande om de hoge productie en waarde van de producten in stand te houden en uit te bouwen. Intensivering is een economisch gedreven proces dat ook leidt tot een toename van de energiebehoefte. Voortdurende innovatie van kassen, teeltsystemen en andere technologische hulpmiddelen zijn vooral gericht op verdere optimalisatie van de productie. Hiermee richt de sector zich

\footnotetext{
1 In beginsel hoort hier ook verkoop van warmte buiten de sector bij maar deze verkoop is heel beperkt en betreft alleen duurzame warmte. Door de beperkte omvang is dit herleidbaar naar individuele bedrijven en de productie van duurzame warmte heeft geen invloed op de $\mathrm{CO}_{2}$-emissie waardoor deze factor buiten beschouwing is getalen.

2 Deze factor betreft alleen het totaal areaal; ontwikkelingen in het areaal per gewas maakt onderdeel uit van de factor energiegebruik per $\mathrm{m}^{2}$ (structuureffect).

3 Inkoop van warmte betreft inkoop van niet-duurzame warmte (restwarmte) en wordt in deze rapportage inkoop van warmte genoemd.
} 
op het leveren van kwaliteitsproducten om te beantwoorden aan de vraag vanuit de topsegmenten van de internationale markt. Dit leidt tot meer gewassen met een grotere energiebehoefte, maar ook tot toenemende productie in de winterperiode met groeilicht. Intensivering brengt hierdoor een hogere energievraag per $\mathrm{m}^{2}$ kas met zich mee.

\section{Extensivering}

Naast intensivering vinden er ontwikkelingen plaats waardoor er juist minder energie-intensieve gewassen worden geteeld, bijvoorbeeld door een verminderde vraag vanuit de markt naar energieintensieve gewassen en/of een sterkere vraag naar energie-extensievere gewassen. Door veranderingen in de sectorstructuur (areaal per gewas) kan het gemiddelde energiegebruik per $\mathrm{m}^{2}$ kas dalen, in dat geval is er sprake van extensivering.

\section{Energiebesparing}

Naast extensivering kan de energievraag per $\mathrm{m}^{2}$ kas ook dalen door energiebesparing. Mogelijke opties hiervoor zijn nieuwe kassen, (extra) energieschermen, efficiëntere lampen en energiezuinige teeltstrategieën zoals Het Nieuwe Telen (HNT). HNT is een innovatieve energiezuinige teeltstrategie voor regeling van het kasklimaat waarbij gebruik wordt gemaakt van natuur- en plantkundige kennis om de teelt optimaal te sturen voor wat betreft temperatuur, vocht, $\mathrm{CO}_{2}$-niveau, licht en het gebruik van schermen. HNT ontwikkelt zich verder en staat door een positieve invloed op de teelt sterk in de belangstelling.

\section{Effecten $\mathrm{CO}_{2}$-emissie}

Een onderzoek naar de effecten van intensivering, extensivering en energiebesparing op de $\mathrm{CO}_{2}$-emissie in de periode 2020-2015 door Wageningen Economic Research is in 2017 gepubliceerd (Van der Velden en Smit, 2017). Op de bevindingen wordt in paragraaf 2.5 voortgebouwd in de kwantitatieve analyse van de ontwikkeling van de $\mathrm{CO}_{2}$-emissie.

\section{Energievoorziening zonder $\mathrm{CO}_{2}$-emissie}

Naast de energievraag is de wijze waarop in de energievraag wordt voorzien van grote invloed op de ontwikkeling van de $\mathrm{CO}_{2}$-missie van de glastuinbouw. Warmte uit aardgasgestookte ketels is al lange tijd niet meer de belangrijkste energievoorziening. Door de tuinders wordt een mix ingezet van wkk, ketels, duurzame energiebronnen en inkoop van warmte en elektriciteit. Ook wordt er elektriciteit en in geringe mate warmte verkocht.

Door het gebruik van duurzame energie en de inkoop van warmte en elektriciteit bestaat een deel van energievoorziening uit bronnen zonder fossiel brandstofverbruik c.q. $\mathrm{CO}_{2}$-emissie van de glastuinbouw. Voorbeelden van duurzame energiebronnen in de glastuinbouw zijn aardwarmte, zonne-energie, biobrandstof en inkoop duurzame warmte en duurzame elektriciteit. Daarnaast brengt de inkoop van niet duurzame warmte en elektriciteit van buiten de glastuinbouwsector ook geen $\mathrm{CO}_{2}$-emissie van de glastuinbouw met zich mee.

\subsection{De Energiemonitor}

In de Energiemonitor van de Nederlandse Glastuinbouw wordt de ontwikkeling van de $\mathrm{CO}_{2}$-emissie gekwantificeerd en van achtergronden en duiding voorzien. Dit wordt gedaan voor de achterliggende indicatoren van de $\mathrm{CO}_{2}$-emissie, energie-efficiëntie en het aandeel duurzame energie. Als basis hiervoor wordt de energiebalans van de glastuinbouw opgesteld. De energiebalans omvat de energieinput en de energie-output van de sector. Om de energie-efficiëntie te kunnen bepalen, wordt ten slotte ook de ontwikkeling van de fysieke productie van de glastuinbouw gekwantificeerd.

Deze rapportage bevat de definitieve resultaten tot en met 2018 en - op basis van de medio 2020 beschikbare informatie - de voorlopige resultaten van 2019. De ontwikkeling van de $\mathrm{CO}_{2}$-emissie, de achterliggende indicatoren en de factoren van invloed op de ontwikkeling komen aan bod in hoofdstuk 2 . In hoofdstuk 3 is het gebruik van duurzame energie nader geanalyseerd. wkk, warmteinkoop en de elektriciteitsbalans van de glastuinbouw zijn nader geanalyseerd in hoofdstuk 4 . In hoofdstuk 5 volgt de reflectie. Ten slotte bevat hoofdstuk 6 de conclusies. 


\section{Energie-indicatoren op sectorniveau}

\section{$2.1 \quad$ Inleiding}

In dit hoofdstuk wordt de ontwikkeling van de energie-indicatoren op sectorniveau behandeld. In de volgende paragraaf is dat de $\mathrm{CO}_{2}$-emissie. Hierna komen de energie-efficiëntie en het aandeel duurzame energie aan bod. De kwantitatieve effecten van de invloedsfactoren op de $\mathrm{CO}_{2}$-emissie, de energiekosten, het energiegebruik en het aandeel van de energievoorziening zonder $\mathrm{CO}_{2}$-emissie komen in de vier paragrafen daarna aan bod.

Een belangrijk element bij de ontwikkeling van de indicatoren $\mathrm{CO}_{2}$-emissie en energie-efficiëntie is de ontwikkeling van het areaal. Op basis van de Landbouwtelling (LBT) van het CBS is het areaal in 2019 met zo'n 700 ha (8\%) toegenomen. Vanuit de beschikbare inzichten is de mutatie in 2019 maar voor een klein deel het gevolg van de werkelijke fysieke wijzigingen, oftewel het saldo van nieuwbouw en sloop. In het aparte tekstkader op de volgende pagina wordt hier nader op ingegaan en worden de kwalitatieve effecten op de indicatoren $\mathrm{CO}_{2}$-emissie en energie-efficiëntie uiteengezet.

\section{$2.2 \quad \mathrm{CO}_{2}$-emissie}

\section{$\mathrm{CO}_{2}$-emissie}

In 2019 bedroeg de $\mathrm{CO}_{2}$-emissie 5,9 Mton. Dit is een toename met 0,2 Mton t.o.v. 2018 (5,7 Mton). De $\mathrm{CO}_{2}$-emissie lag in 2019 daarmee 0,3 Mton onder het oorspronkelijke doel van 6,2 Mton voor 2020 in de Meerjarenafspraak. In vergelijking met het $\mathrm{CO}_{2}$-doel voor 2020 na technische correctie (4,6 Mton) lag de werkelijke $\mathrm{CO}_{2}$-emissie in 2019 1,3 Mton (14\%) boven het doel. Om dit doel te

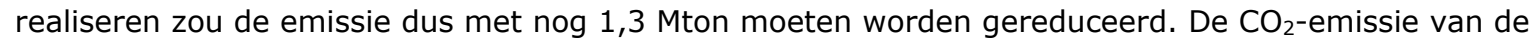
glastuinbouw lag in de jaren 2015 tot en met 2018 stabiel rond het niveau van 5,7 Mton (figuur 2.1). De stabilisering volgde na een sterke daling van 2,4 Mton in de periode 2010-2014.

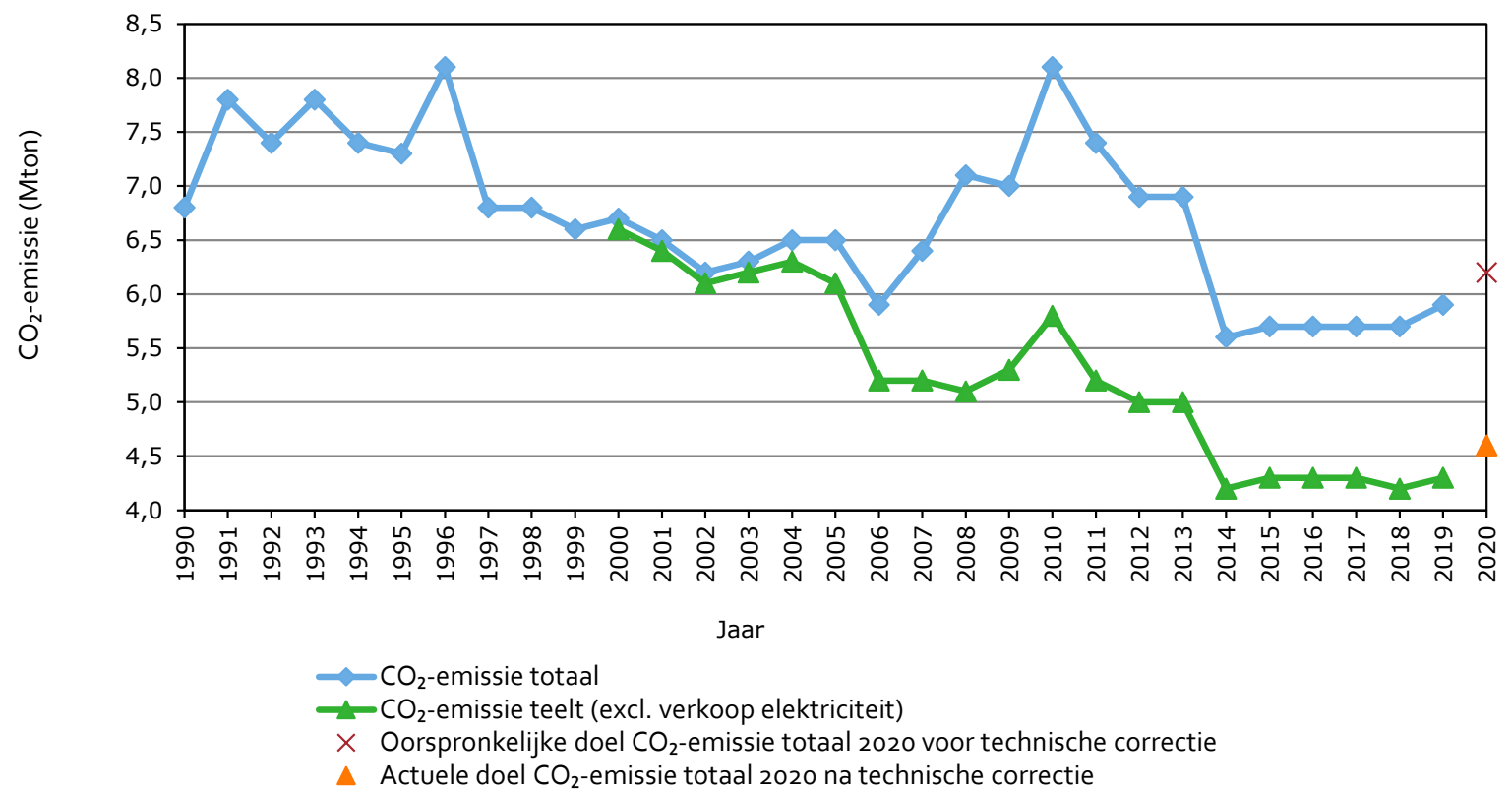

Figuur $2.1 \mathrm{CO}_{2}$-emissie van de glastuinbouw per jaar en het doel voor 2020 a) a) Cijfers 2019 voorlopig. 


\section{Definitie areaal glastuinbouw}

- In de Meerjarenafspraak Energietransitie Glastuinbouw 2014-2020 en in het Protocol van de Energiemonitor van de Nederlandse glastuinbouw is de sector glastuinbouw gedefinieerd als het areaal glastuinbouw in de Landbouwtelling (LBT) van het Centraal Bureau voor de Statistiek (CBS). Voor de Energiemonitor wordt daardoor uitgegaan van het areaal in de LBT, zowel totaal in Nederland als per gewas(groep).

\section{Landbouwtelling 2019}

- In 2019 is het areaal glastuinbouw in de LBT met zo'n 700 ha (8\%) toegenomen. Bovendien is de totale areaalmutatie niet proportioneel verdeeld over de afzonderlijke gewassen.

- Vanuit de beschikbare inzichten is de totale areaalmutatie in 2019 maar voor een klein deel het gevolg van de werkelijke fysieke wijzigingen oftewel het saldo van nieuwbouw en sloop.

- De LBT omvat bedrijven/vestigingen die de LBT in de 'Gecombineerde Opgave' hebben ingevuld en bedrijven/vestigingen die door het CBS zijn bijgeschat. Uit nadere analyse van de data blijkt dat in 2019 meer bedrijven/vestigingen de LBT hebben ingevuld en minder bedrijven/vestigingen zijn bijgeschat. Per saldo blijkt dat in 2019 meer bedrijven/vestigingen deel uit maken van de LBT en het areaal groter is.

- Door het voorgaande is het aannemelijk dat de LBT in eerdere jaren een te laag areaal gaf en in 2019 dichter bij de werkelijke situatie zit.

- Op de vraag of de LBT in 2019 het complete areaal glastuinbouw in Nederland omvat, bestaat geen duidelijk antwoord.

\section{Effecten op de Energiemonitor}

- In combinatie met de bottom-up benadering voor het bepalen van het energiegebruik op sectorniveau in de methodiek van de Energiemonitor glastuinbouw (zie Protocol) brengt het grotere areaal in 2019 met zich mee dat het totaal energiegebruik, het aardgasverbruik, de verkoop en inkoop elektriciteit, het wkk-vermogen en daarmee de elektriciteitsproductie op sectorniveau toeneemt. Naast het totaal areaal is ook het areaal per gewas(groep) van invloed.

- De energie-efficiëntie wordt berekend door het quotiënt van het primair brandstofverbruik per $\mathrm{m}^{2}$ en de fysiek productie per $\mathrm{m}^{2}$ (zie Protocol).

- Door de bottom-up benadering bij het bepalen van het energiegebruik ${ }^{4}$ wordt het primair brandstofverbruik per $\mathrm{m}^{2}$ niet beïnvloed door de toename van het areaal.

- De fysieke productie per $\mathrm{m}^{2}$ wordt voor de sierteelt (bloemen en planten) top-down berekend (zie Protocol). De totale fysieke productie wordt hierbij gedeeld door het areaal. Hierdoor wordt de fysieke productie per $\mathrm{m}^{2}$ beïnvloed door de toename van het areaal. Bij de groente wordt de fysieke productie bottum-up bepaald (zie Protocol) waardoor dit niet beïnvloed wordt door het totaal areaal; eventueel wel door het areaal per gewas(groep). Hierdoor daalt per saldo de fysieke productie per $\mathrm{m}^{2}$ en verslechterd de energie-efficiëntie.

- De toename van het areaal heeft geen invloed op het gebruik van duurzame energie en inkoop van warmte van buiten de sector. Deze worden beiden bepaald met een inventarisatie op projectniveau en daarop heeft het areaal in de LBT geen invloed.

\section{Effecten op $\mathrm{CO}_{2}$-emissie van de glastuinbouw}

- Door de toename van het areaal neemt het totaal aardgasverbruik en dus de $\mathrm{CO}_{2}$-emissie toe.

- Door mutaties van het areaal per gewas (structuur effect) ontstaat er op sectorniveau intensivering en extensivering. Hierdoor wijzigt het gemiddeld energiegebruik per $\mathrm{m}^{2}$. Ook dit is van invloed op de $\mathrm{CO}_{2}-$ emissie. De areaaltoename in 2019 zit meer bij de energie-extensieve dan bij de energie-intensieve gewassen. Dit bracht een verlaging van het gemiddeld aardgasgebruik per $\mathrm{m}^{2}$ met zich mee. Hierdoor nam de $\mathrm{CO}_{2}$-emissie in 2019 door het areaal procentueel minder toe dan het areaal.

- Naast het directe effect van het areaal zijn er ook indirecte defecten. Door de toename van het areaal neemt ook de inkoop en verkoop elektriciteit toe. Door het eerste neemt de $\mathrm{CO}_{2}$-emissie af en door het tweede neemt de $\mathrm{CO}_{2}$-emissie toe.

\section{Temperatuurcorrectie}

De $\mathrm{CO}_{2}$-emissie wordt volgens de afspraken in het convenant niet gecorrigeerd voor verschillen in de buitentemperatuur tussen jaren. De jaren in de periode 2014 tot en met 2019 waren relatief warm. De toename van de $\mathrm{CO}_{2}$-emissie in 2019 ten opzichte van 2018 na temperatuurcorrectie bedraagt evenals voor temperatuurcorrectie - ook 0,2 Mton.

\footnotetext{
4 Sinds de liberalisering van de Energiemarkt in het begin van deze eeuw zijn er geen totaal cijfers over de verkoop van aardgas aan de glastuinbouw meer beschikbaar waardoor een bottom-up methode is ontwikkeld.
} 


\section{$\mathrm{CO}_{2}$-emissie teelt}

Ook de $\mathrm{CO}_{2}$-emisie van de teelt is in 2019 toegenomen en wel van 4,2 naar 4,3 Mton en ligt daarmee 1,7 Mton lager dan de totale $\mathrm{CO}_{2}$-emisie. Het verschil tussen de is de $\mathrm{CO}_{2}$-emissie voor de teelt en de totale $\mathrm{CO}_{2}$-emissie is de $\mathrm{CO}_{2}$-emissie die samengaat met de verkoop van de elektriciteit geproduceerd in de aardgas-wkk's. Dit verschil is in 2019 groter geworden doordat er meer elektriciteit is verkocht (paragraaf 4.5) waardoor de $\mathrm{CO}_{2}$-emissie van de teelt minder toenam.

\section{Externe en interne invloedsfactoren}

De invloedsfactoren op de $\mathrm{CO}_{2}$-emissie (paragraaf 2.5) kunnen worden ingedeeld naar externe en interne factoren. De ontwikkeling van de factoren areaal en verkoop elektriciteit zijn vooral afhankelijk van de vraag naar glastuinbouwproducten en energiekosten. Beiden worden beïnvloed door internationale economische ontwikkelingen. Glastuinbouwbedrijven hebben hierop weinig invloed. De ontwikkeling van de invloedsfactoren areaal en verkoop elektriciteit worden daardoor geschaard onder externe factoren. De invloedsfactoren duurzame energie, inkoop van warmte, inkoop elektriciteit en energiegebruik per $\mathrm{m}^{2}$ zitten meer in de invloedsfeer van de glastuinbouw zelf en worden geschaard onder de interne factoren.

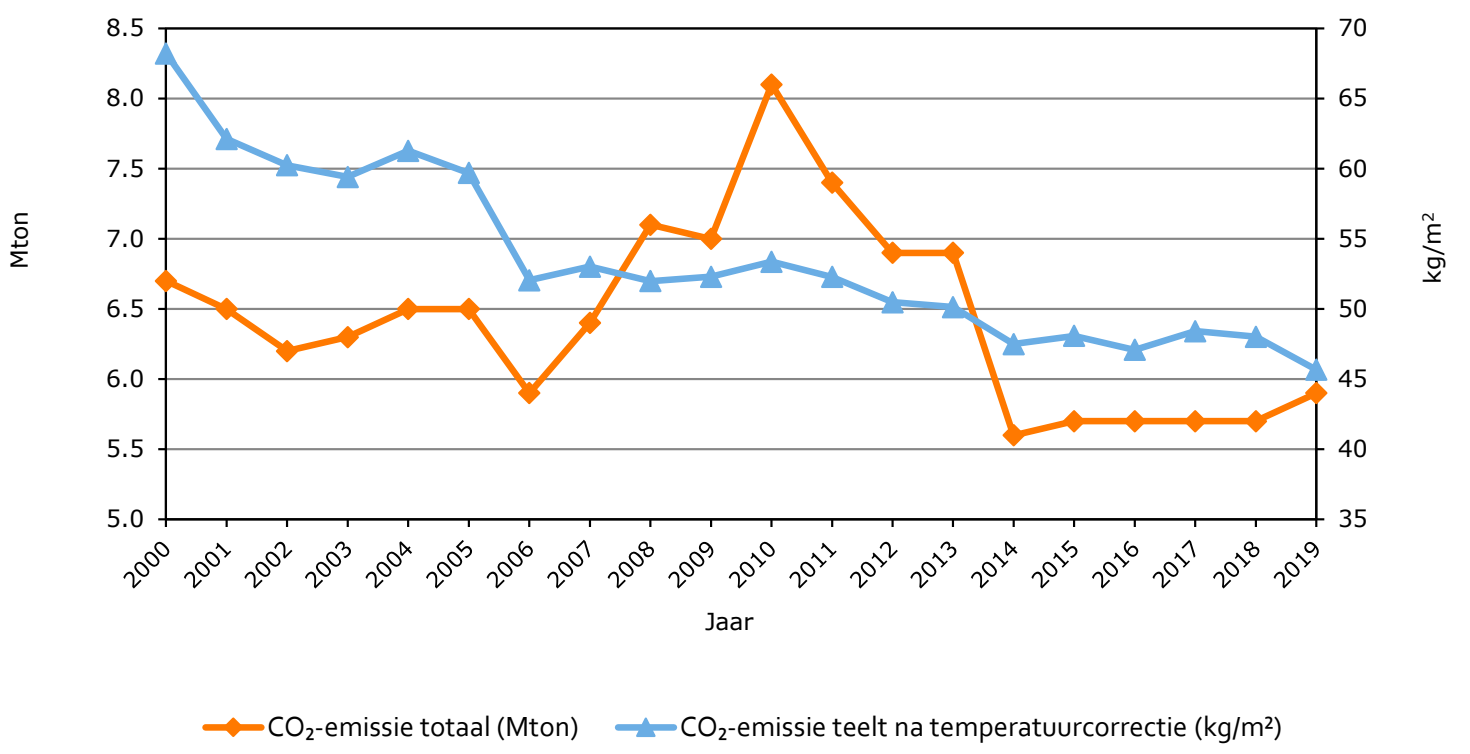

Figuur 2.2 $\mathrm{CO}_{2}$-emissie totaal en $\mathrm{CO}_{2}$-emissie van de teelt per $\mathrm{m}^{2}$ na temperatuurcorrectie a) a) Cijfers 2019 voorlopig.

\section{$\mathrm{CO}_{2}$-emissie teelt per $\mathrm{m}^{2}$}

Voor het inzicht in de reductie door de glastuinbouw zelf geeft de indicator $\mathrm{CO}_{2}$-emissie per $\mathrm{m}^{2} \mathrm{kas}$ van de teelt na temperatuurcorrectie inzicht. Deze indicator is onafhankelijk van de externe invloedsfactoren areaal, verkoop elektriciteit en van de buitentemperatuur. Deze $\mathrm{CO}_{2}$-emissie van de teelt per $\mathrm{m}^{2}$ (figuur 2.2) is in de periode 2010-2014 gedaald, in de periode 2014-2018 min of meer stabiel en in 2019 wederom gedaald. De reductie van de emissie van de teelt per $\mathrm{m}^{2}$ geeft vooral in 2019 een tegengesteld beeld in vergelijking met de totale $\mathrm{CO}_{2}$-emissie van de glastuinbouw die in 2019 juist toenam. Dit verschil komt door de sterke toename van het areaal in de LBT. Ook over de gehele periode 2010-2018 zien we een reductie van de emissie van de teelt per $\mathrm{m}^{2}$. Deze reductie werd vooral veroorzaakt door de toename van het gebruik van duurzame energie en inkoop elektriciteit, beide over de gehele periode en de vermindering van het energiegebruik per $\mathrm{m}^{2}$ in de periode 2010-2014. Achter het energiegebruik per $\mathrm{m}^{2}$ zitten de processen intensivering, extensivering en energiebesparing. De areaalmutatie in 2019 verschilt per gewas(groep) en dat is van invloed op de intensivering en de extensivering. 


\section{$\mathrm{CO}_{2}$-emissie Nederland}

Voor Nederland als geheel kwam de $\mathrm{CO}_{2}$-emissie in 2019 uit op 156,6 Mton (CBS Statline, bijlage 2). Dit is 4\% minder dan in 1990. In de glastuinbouw ligt de $\mathrm{CO}_{2}$-emissie in 2019 14\% onder het niveau van 1990 en de $\mathrm{CO}_{2}$-emissie van de teelt ligt 37\% onder het niveau van 1990. Het reduceren van de $\mathrm{CO}_{2}$-emissie gaat in de glastuinbouw dus sneller dan landelijk. Dit terwijl de sector een substantiële hoeveelheid elektriciteit met wkk op aardgas produceert en verkoopt.

\section{Warmtekrachtkoppeling}

De glastuinbouw produceerde in 2019 circa 10,4 miljard kWh elektriciteit met aardgas-wkk (hoofdstuk 4). Dit is de grootste hoeveelheid sinds de monitor is gestart. De productie was in $201910 \%$ meer dan in 2018 en $1 \%$ meer dan in 2012. Het jaar 2012 was voor 2019 het jaar met de hoogste productie maar nu is dat 2019. Met de productie in 2019 werd op nationaal niveau op basis van het primair brandstofverbruik (paragraaf 2.3) 1,6 Mton $\mathrm{CO}_{2}$-emissie vermeden. Deze vermeden $\mathrm{CO}_{2}$-emissie kwam door benutting van de warmte die geproduceerd wordt bij de elektriciteitsproductie met wkk. Hierdoor daalde het brandstofverbruik in elektriciteitscentrales met 2,5 miljard $\mathrm{m}^{3}$ aardgasequivalenten en nam het aardgasverbruik in de glastuinbouw met 1,6 miljard $\mathrm{m}^{3}$ toe. Dit laatste is het saldo van het extra aardgasverbruik in de wkk's (3,0 miljard $\left.\mathrm{m}^{3}\right)$ minus het verminderde verbruik in de ketels $\left(1,4\right.$ miljard $\left.\mathrm{m}^{3}\right)$. Per saldo werd er op nationaal niveau 0,9 miljard $\mathrm{m}^{3}$ aardgasequivalenten aan primair brandstof bespaard door de aardgas-wkk's in de glastuinbouw.

\subsection{Energie-efficiëntie}

De energie-efficiëntie-index is in 2019 ten opzichte van 2018 met 1 procentpunt verslechterd naar 45\% (figuur 2.3). De glastuinbouw gebruikte daarmee in 2019 55\% minder primair brandstof per eenheid product dan in 1990. De toename in 2019 kwam door daling van zowel het primair brandstofverbruik per $\mathrm{m}^{2}(-3 \%)$ als van de fysieke productie per $\mathrm{m}^{2}(-7 \%)$. Hierbij was de daling van het primair brandstofverbruik per $\mathrm{m}^{2}$ kleiner van de daling van de fysiek productie per $\mathrm{m}^{2}$ waardoor de energie-efficiëntie verslechterde.

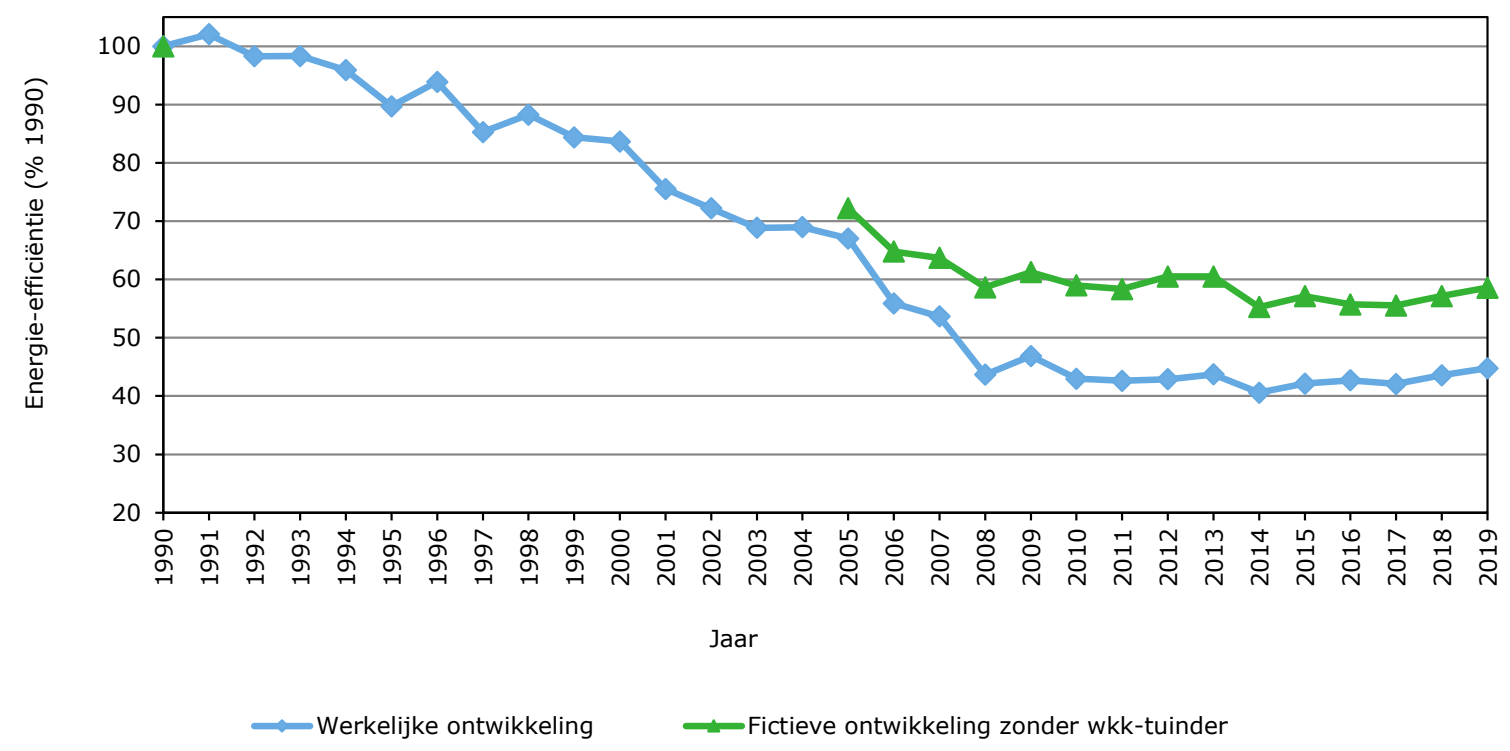

Figuur 2.3 Energie-efficiëntie in de productieglastuinbouw per jaar met en zonder wkk a) a) Cijfers 2019 voorlopig.

Als de afgelopen jaren worden beschouwd, is de energie-efficiëntie-index in de periode 2014-2018 verslechterd van 41 naar 45\% (figuur 3.2). In de periode 2010-2014 was de energie-efficiëntie min of meer stabiel. De periode hiervoor was er een sterke verbetering. De afvlakking na 2008 komt mede door het nastreven van een hogere waarde per eenheid product en marktvraag gericht op productie in 
de winterperiode met belichting. De eerste ontwikkeling remt de ontwikkeling van de fysieke productie en de tweede doet het primair brandstofverbruik toenemen.

\section{Primair brandstofverbruik}

Het primair brandstofverbruik per $\mathrm{m}^{2}$ nam in 2019 met 3\% af (figuur 2.4). De sterke toename van het gebruik van duurzame warmte (hoofdstuk 3 ) en de toename van de verkoop van elektriciteit (hoofdstuk 4) deden het primair brandstofverbruik dalen. De toename van inkoop elektriciteit zorgde daarentegen voor een stijging. Over de gehele periode 2010-2018 nam het primair brandstofverbruik per $\mathrm{m}^{2}$ geleidelijk toe. In de eerste 4 jaar was deze ontwikkeling wat minder sterk dan in de tweede 4 jaar. Dit kwam vooral door de vermindering van het energiegebruik per $\mathrm{m}^{2}$ in de eerste 4 jaar en de toename daarvan in de tweede 4 jaar. Daarnaast hadden de verminderde hoeveelheid elektriciteit die werd verkocht in de eerste 4 jaar en de geleidelijke toename van inkoop elektriciteit over beide perioden een negatieve invloed. De toename van duurzame energie had over beide perioden een positieve invloed.

\section{Fysieke productie}

De fysieke productie per $\mathrm{m}^{2}$ vertoont vanaf 1990 een stijgende trend. Wel zijn er verschillen tussen de jaren (figuur 2.3 en bijlage 2). Over de gehele periode 1990-2017 nam de fysieke productie per $\mathrm{m}^{2}$ met circa de helft toe. Dat is gemiddeld 1,5\% per jaar. In de periode 1990-2008 was dit 2\% per jaar. Vanaf 2008 vlakte de groei af. In de periode 2008-2017 was de groei gemiddeld 1,0\% per jaar. Dit hangt samen met de vraag vanuit de afzetmarkt naar kwaliteitsproducten en de planning van de afzet van de productie, oftewel een verschuiving van kwantiteit naar kwaliteit. Na 2017 en vooral in 2019 nam de fysieke productie af. Dit laatste hing samen met de sterke toename van het areaal in 2019 (paragraaf 2.1).

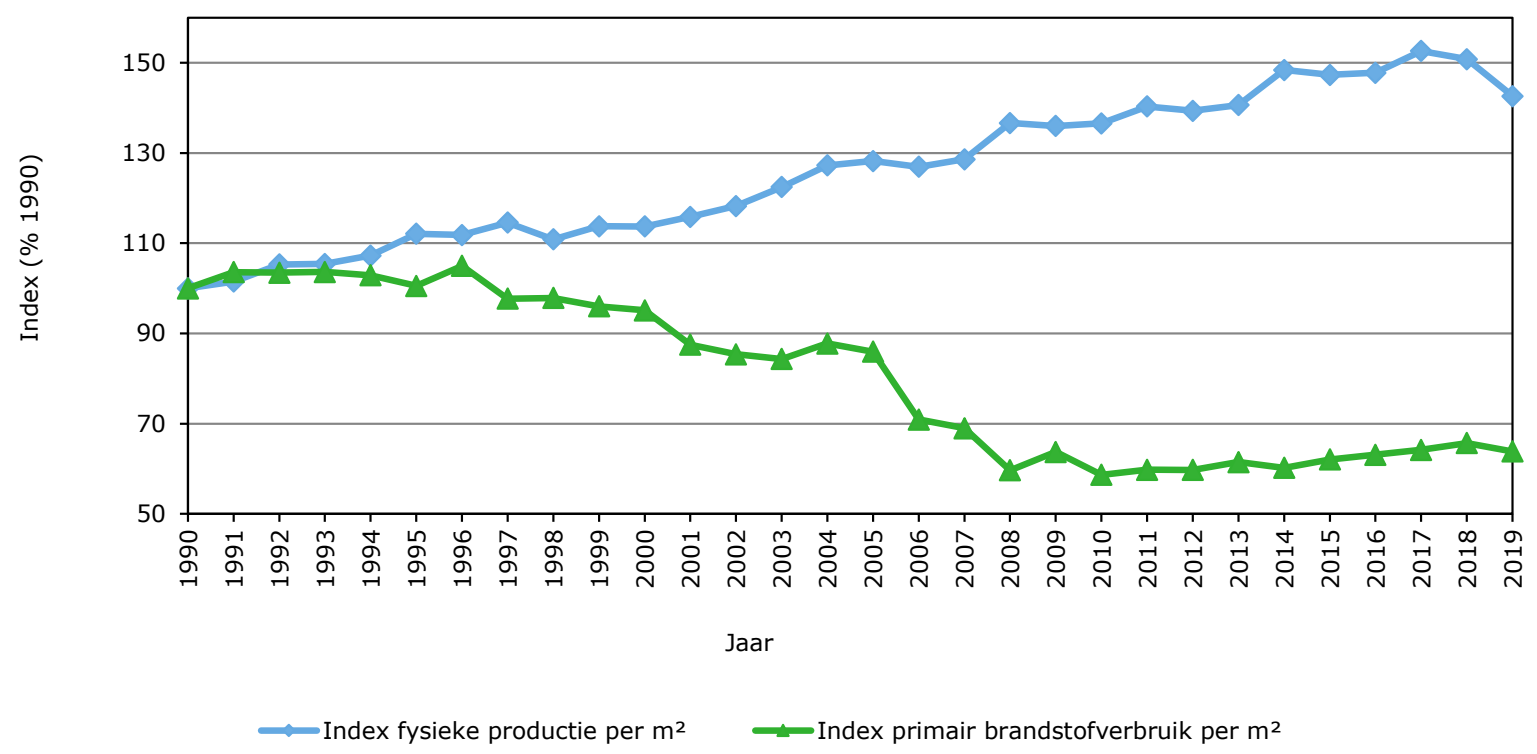

Figuur 2.4 Fysieke productie en primair brandstofverbruik in de productieglastuinbouw per $m^{2}$ kas a) a) Cijfers 2019 voorlopig.

\section{Effect warmtekrachtkoppeling}

Het gebruik van wkk heeft een positief effect op de energie-efficiëntie, omdat bij de productie van elektriciteit ook de vrijkomende warmte nuttig wordt ingezet. Dit in tegenstelling tot de productie in elektriciteitscentrales waar de vrijkomende warmte meestal wordt geloosd (hoofdstuk 4). In 2012 lag het effect van het gebruik van wkk op ongeveer 18 procentpunten in vergelijking met een situatie zonder wkk (figuur 2.2). In de periode 2012-2016 was dit effect teruggelopen tot 13 procentpunten. De vermindering hangt samen met de verminderde elektriciteitsproductie door wkk voor de verkoop. Dit kwam door een spark spread die minder gunstig was voor wkk. Na 2016 nam het effect van wkk op de energie-efficiëntie weer toe tot 14 procentpunt in 2019. De spark spread was gunstiger en mede 
hierdoor nam de elektriciteitsverkoop toe. Het effect werd geremd door toename van de eigen consumptie van de elektriciteit geproduceerd met de wkk.

\subsection{Aandeel duurzame energie}

Gebruik duurzame energie sterk toegenomen

Het gebruik van duurzame energie in het totaal energiegebruik is in 2019 sterk toegenomen en wel van 7,4 naar 9,4\% (figuur 2.5). Deze groei kwam doordat het gebruik van duurzame energie meer toenam dan het totaal energiegebruik steeg. Het absolute gebruik nam toe van 7,4 naar 10,0 PJ. Dit is een toename met $35 \%$ in 1 jaar en is de sterkste toename sinds de monitor van duurzame energie in 2000 werd gestart. In de periode 2010-2019 groeide het aandeel duurzame energie in de glastuinbouw met bijna 7,5 procentpunten en is sinds 2015 bijna verdubbeld.

Zowel het absolute gebruik van duurzame energie als het aandeel in het totaal energiegebruik vertonen vanaf 2000 een toename. Vanaf 2013 zijn de toenames sterker. De toename van het absolute gebruik bedroeg in de periode 2013-2019 circa 250\% en het aandeel liet bijna een verdubbeling zien. In 2019 was de toename van het aandeel duurzaam kleiner dan van het absolute gebruik. Dit kwam doordat het totaal energiegebruik van de glastuinbouw in 2019 toenam (bijlage 2).

Duurzame energie die door de glastuinbouw werd toegepast, bestond voor circa $86 \%$ uit warmte en voor $14 \%$ uit elektriciteit. De totaal toegepaste hoeveelheid duurzame energie werd voor circa $62 \%$ door de sector zelf geproduceerd en voor circa 38\% ingekocht. Van de toegepaste duurzame warmte kwam $72 \%$ uit productie door de sector zelf. De toegepaste duurzame elektriciteit werd voor $96 \%$ ingekocht. De hoeveelheid duurzame energie die door de glastuinbouw aan afnemers buiten de sector werd verkocht was beperkt (0,2 PJ).

\section{Aandeel glastuinbouw hoger dan in Nederland}

Voor Nederland als geheel bedroeg het aandeel duurzame energie in 2018 7,4 en in 2019 8,7\% (CBS, Statline, bijlage 2). Het aandeel duurzame energie in de glastuinbouw komt daarmee in 2019 voor het eerst hoger uit dan het landelijk aandeel (figuur 2.4). In 2010 bedroeg het aandeel in de glastuinbouw nog maar de helft van het aandeel in geheel Nederland. Het aandeel in de glastuinbouw groeide in de periode 2010-2019 in de glastuinbouw dus sterker dan in Nederland als geheel.

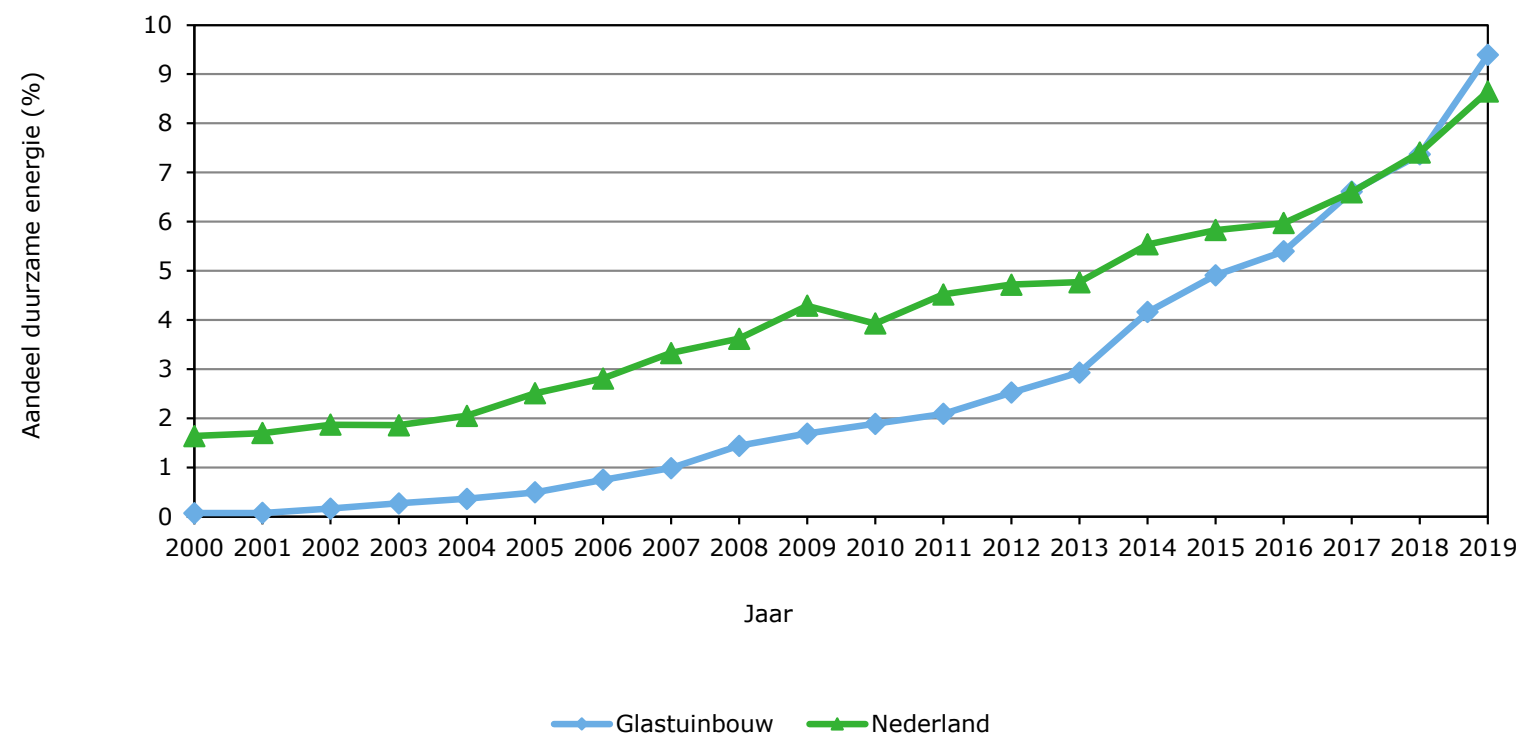

Figuur 2.5 Aandeel duurzame energie in de glastuinbouw en in Nederland per jaar a) a) Cijfers 2018 voorlopig. 
Het gebruik van duurzame energie had in 2019 een positief effect op de $\mathrm{CO}_{2}$-emissie op sectorniveau

van ruim 0,5 Mton. Op de energie-efficiëntie was het effect ruim 5 procentpunten (paragraaf 3.4).

\subsection{Kwantitatieve analyse ontwikkeling $\mathrm{CO}_{2}$-emissie}

\section{Inleiding}

In de periode 2010-2014 daalde de $\mathrm{CO}_{2}$-emissie (voor temperatuurcorrectie) van de glastuinbouw met 2,5 Mton en in de periode 2014-2018 trad een toename op met 0,1 Mton (figuur 2.1). Ook in 2019 trad een toename op, de $\mathrm{CO}_{2}$-emissie steeg met 0,2 Mton.

In deze paragraaf worden de achtergronden van de ontwikkelingen in deze perioden kwantitatief geanalyseerd. Hierbij worden de perioden 2010-2014 en 2014-2018 en het jaar 2019 afzonderlijk in beschouwing genomen.

\section{Buitentemperatuur}

De jaren 2014, 2018 en 2019 waren relatief warm en 2010 relatief koud. Als voor de buitentemperatuur wordt gecorrigeerd, bedraagt de daling van de $\mathrm{CO}_{2}$-emissie in de periode 20102014 1,9 Mton in plaats van 2,5 Mton en blijft deze in de periode 2014-2018 gelijk. In de eerste periode was er dus ook na temporatuurcorrectie een substantiële daling en in de tweede periode was de $\mathrm{CO}_{2}$-emissie stabiel. In 2019 trad ook na temperatuurcorrectie een toename op van 0,2 Mton.

De $\mathrm{CO}_{2}$-emissie na temperatuurcorrectie is het vertrekpunt voor de analyse van de effecten van de overige invloedsfactoren (tabel 2.1). Na de invloed van de buitentemperatuur wordt de ontwikkeling van de $\mathrm{CO}_{2}$-emissie bepaald door de zes onderstaande invloedsfactoren (zie ook paragraaf 1.2):

1. areaal glastuinbouw

2. verkoop elektriciteit

3. gebruik duurzame energie

4. inkoop van warmte

5. inkoop elektriciteit

6. energiegebruik per $\mathrm{m}^{2}$.

Analyse

Van de eerste 5 factoren is kwantitatieve informatie beschikbaar. De laatste factor, het energiegebruik per $\mathrm{m}^{2}$, wordt bepaald door de 3 achterliggende factoren intensivering, extensivering en energiebesparing (zie ook paragraf 1.2). Over deze 3 afzonderlijke factoren binnen de glastuinbouw is weinig kwantitatieve informatie beschikbaar. De ontwikkeling hiervan vindt immers gezamenlijk achter de energiemeters plaats. Het gezamenlijk effect is daarom als saldo gekwantificeerd. Door intensivering neemt het energiegebruik toe en door extensivering en energiebesparing neemt het energiegebruik af.

In de analyse van de effecten van de invloedsfactoren is onderscheid gemaakt naar de periode 20102014 en 2014-2018 en het jaar 2019 (tabellen 2.1. en 2.2). Voor de inhoudelijke uitleg van de kwantificering van de effecten wordt verwezen naar de Energiemonitor Glastuinbouw 2017 (Van der Velden en Smit, 2017b) en de analyse van het effect van intensivering, extensivering en energiebesparing (Van der Velden en Smit, 2017). 
Tabel 2.1 Ontwikkeling van de invloedsfactoren a) op de $\mathrm{CO}_{2}$-emissie van de glastuinbouw in de afzonderlijke perioden 2010-2019 (Mton)

\begin{tabular}{|c|c|c|c|c|c|c|c|c|}
\hline \multirow[t]{3}{*}{ Invloedsfactoren } & \multirow[t]{3}{*}{ Eenheid } & \multirow[t]{3}{*}{2010} & \multirow[t]{3}{*}{2014} & \multirow[t]{3}{*}{2018} & \multirow[t]{3}{*}{2019} & \multicolumn{3}{|c|}{ Verschil } \\
\hline & & & & & & 2014 minus & 2018 minus & 2019 minus \\
\hline & & & & & & 2010 & 2014 & 2018 \\
\hline Verkoop elektriciteit & miljard kWh & 8,4 & 5,2 & 5,4 & 5,8 & 3,2 & $+0,2$ & $+0,4$ \\
\hline $\begin{array}{l}\text { Duurzame energie } \\
\text { (warmte en elektriciteit) }\end{array}$ & PJ & 2,4 & 4,0 & 7,4 & 9,4 & $+1,6$ & $+3,4$ & $+2,0$ \\
\hline $\begin{array}{l}\text { Inkoop van warmte } \\
\text { (niet duurzaam) }\end{array}$ & $\mathrm{PJ}$ & 5,3 & 3,4 & 3,4 & 2,8 & 1,9 & 0,0 & 0,6 \\
\hline $\begin{array}{l}\text { Inkoop elektriciteit } \\
\text { (niet duurzaam) }\end{array}$ & miljard kWh & 2,0 & 2,1 & 2,5 & 3,0 & $+0,1$ & $+0,4$ & $+0,5$ \\
\hline
\end{tabular}

a) Exclusief energiegebruik per m2; dit wordt als saldo gekwantificeerd (tabel 2.2).

Tabel 2.2 Effect op $\mathrm{CO}_{2}$-emissie door de invloedsfactoren in de afzonderlijke perioden 2010-2019 (Mton) a)

\begin{tabular}{|c|c|c|c|c|}
\hline \multirow[t]{2}{*}{ Invloedsfactoren } & \multicolumn{4}{|c|}{ Periode } \\
\hline & 2010 tot en met 2014 & 2014 tot en met 2018 & & 2019 \\
\hline Areaal & $-0,42$ & $-0,24$ & $+0,34$ & \\
\hline Duurzame energie & $-0,09$ & $-0,21$ & $-0,14$ & \\
\hline Inkoop van warmte (niet duurzaam) & $+0,11$ & $-0,00$ & $+0,03$ & \\
\hline Subtotaal & $-1,28$ & $-0,52$ & & $+0,22$ \\
\hline Energiegebruik per $\mathrm{m}^{2}$ & $-0,58$ & $+0,39$ & $-0,01$ & \\
\hline Totaal & $-1,86$ & $-0,13$ & & $+0,21$ \\
\hline
\end{tabular}

a) Na temperatuurcorrectie.

Periode 2010-2014

De factoren krimp van het areaal (-0,42 Mton), daling van de verkoop van elektriciteit geproduceerd met de aardgas wkk's $(-0,86)$, toename van duurzame energie $(-0,09)$ en groei inkoop elektriciteit $(-0,02)$ hadden een dalend effect op de $\mathrm{CO}_{2}$-emissie (tabel 2.2). De factor inkoop van warmte $(+0,11)$ had een stijgend effect. De factoren verkoop elektriciteit en krimp van het areaal hadden in de periode 2010-2014 het grootste effect.

Het gezamenlijk effect van deze 5 invloedsfactoren bedroeg in de periode 2010-2014-1,28 Mton $\mathrm{CO}_{2}$. Dit verklaart $69 \%$ van de totale reductie in deze periode. De resterende reductie van $0,58 \mathrm{Mton} \mathrm{CO}_{2}$ was het gezamenlijk effect van intensivering, extensivering en energiebesparing, oftewel het effect van de mutatie van het energiegebruik per $\mathrm{m}^{2}$. De daling van het energiegebruik per $\mathrm{m}^{2}$ in de periode 2010-2014 deed $\mathrm{CO}_{2}$-emissie dalen. Dit betekent dat het gezamenlijk effect van energiebesparing en extensivering groter was dan het effect van intensivering.

Periode 2014-2018

De factoren krimp van het areaal (-0,24 Mton), toename van duurzame energie (-0,21 Mton) en toename inkoop elektriciteit (-0,13 Mton) hadden in de periode 2014-2018 een dalend effect op de $\mathrm{CO}_{2}$-emissie (tabel 2.2). De verkoop van elektriciteit ( $+0,05 \mathrm{Mton}$ ) had een stijgend effect op de $\mathrm{CO}_{2}$-emissie. Inkoop van warmte was in deze periode stabiel en had dus geen effect. De factoren krimp van het areaal en toename duurzame energie hadden in de periode 2014-2018 de grootste invloed op de $\mathrm{CO}_{2}$-emissie.

In de periode 2014-2018 bedroeg het gezamenlijk effect van deze 5 invloedsfactoren -0,52 Mton $\mathrm{CO}_{2}$. Voor het gezamenlijk effect van intensivering, extensivering en energiebesparing, ofwel het effect van de mutatie van het energiegebruik per $\mathrm{m}^{2}$ resteerde een toename van de $\mathrm{CO}_{2}$-emissie met 0,39 Mton. In tegenstelling tot de periode 2010-2014 deed de toename van het energiegebruik per $\mathrm{m}^{2}$ de 
$\mathrm{CO}_{2}$-emissie stijgen. Dit betekent dat in deze periode het effect van intensivering was groter dan het gezamenlijke effect van extensivering en energiebesparing.

\section{9}

In 2019 is de $\mathrm{CO}_{2}$-emissie ten opzichte van 2018 zowel zonder als met temperatuurcorrectie gestegen met 0,2 Mton. Ook waren de effecten op de $\mathrm{CO}_{2}$-emissie van de meeste afzonderlijke invloedsfactoren groter dan de jaarlijkse effecten in de perioden daarvoor. Dit hangt deels samen met de sterke toename van het areaal. Op een groter areaal wordt bijvoorbeeld meer elektriciteit ingekocht, geproduceerd en verkocht ${ }^{5}$. Hieronder volgen de ontwikkelingen per invloedsfactor in 2019:

- Areaal Volgens de LBT van het CBS daalde het areaal in 2018 met 80 ha $(-1 \%)$ en steeg het in 2019 met 698 ha (+8). Door de toename in het areaal nam de $\mathrm{CO}_{2}$-emissie in 2019 met 0,34 Mton toe.

- Verkoop elektriciteit De verkoop van elektriciteit nam wederom toe in 2019. In 2019 was de stijging (+7\%) sterker dan in $2018(+1 \%)$. Door de groei van de verkoop van elektriciteit nam de $\mathrm{CO}_{2}$-emissie in 2019 met 0,11 Mton toe.

- Duurzame energie Het gebruik van duurzame energie (warmte en elektriciteit) nam zowel in 2018 als in 2019 toe. In 2019 (+35\%) was de toename sterker dan in 2018 (+11\%). Door de groei van het gebruik van duurzame energie nam de $\mathrm{CO}_{2}$-emissie in 2019 met 0,14 Mton af.

- Inkoop van warmte (exclusief duurzaam)

De inkoop van warmte is in $2019(-17 \%)$ evenals in 2018 (-8\%) afgenomen. Dit komt vooral door de toename van het aandeel duurzame warmte bij de restwarmteprojecten; hierdoor neemt het niet duurzame deel af. De duurzame fractie wordt meegenomen bij duurzame energie. Door de daling bij inkoop van warmte nam de $\mathrm{CO}_{2}$-emissie in 2019 met 0,03 Mton toe.

- Inkoop elektriciteit Na de beperkte groei in 2018 (+3\%) nam de inkoop elektriciteit in $2019(+13 \%)$ sterk toe. Door de toename bij inkoop elektriciteit nam de $\mathrm{CO}_{2}$-emissie in 2019 met 0,12 Mton af.

- Energiegebruik per $\mathrm{m}^{2}$ Het effect van energiegebruik per $\mathrm{m}^{2}$ is het saldo van de effecten van intensivering, extensivering en energiebesparing. Dit totaal effect nam in 2018 (+1\%) licht toegenomen en in $2019(-2 \%)$ licht af. De intensivering en extensivering wordt mede beïnvloed door de areaalmutaties per gewas. Zowel in 2018 en in 2019 nam het warmtegebruik per $\mathrm{m}^{2}$ af en het gebruik van elektriciteit per $\mathrm{m}^{2}$ toe (paragraaf 2.7). Het effect op de $\mathrm{CO}_{2}$-emissie was in 2019 een afname van 0,01 Mton. Doordat het totale effect een (kleine) afname van de $\mathrm{CO}_{2}$-emissie laat zien, is het gezamenlijk effect van extensivering en energiebesparing in 2019 (iets) groter geweest dan het effect van intensivering. In 2018 was het tegenovergestelde het geval.

Samengevat brachten in 2019 vooral de toename van het areaal en in mindere mate de toename van verkoop van elektriciteit en de afname van inkoop van warmte een stijging van de $\mathrm{CO}_{2}$-emissie met zich mee. Deze stijging werd in afnemende volgorde gedeeltelijk gedempt door de groei van duurzame energie en de toename van de inkoop elektriciteit.

\subsection{Energiekosten}

\section{Dominante factor $w k k$}

Voor de energiekosten van de glastuinbouw zijn het gebruik van aardgas en daarbinnen het gebruik van aardgas in wkk's dominante factoren. Het gebruik van wkk gaat samen met inkoop van aardgas, verkoop van elektriciteit en eigen gebruik van elektriciteit geproduceerd met wkk. Door de verkoop van energie zijn voor de glastuinbouw de netto-energiekosten (inkoop minus verkoop) van belang. De netto-energiekosten worden bepaald door de hoeveelheid energie die wordt gekocht en verkocht en de bijbehorende kosten en opbrengsten.

\footnotetext{
5 Zowel het gebruik van duurzame warmte als de inkoop van warmte worden niet beïnvloed door de statistische stijging van het areaal. De informatie over deze energiebronnen is afkomstig van inventarisaties van de bestaande projecten.
} 


\section{Inkoop en verkoop}

De kosten voor de inkoop van energie bestaan uit de commodityprijs, de dienstenkosten en heffingen. De opbrengsten van de verkoop betreffen alleen de commodity prijs, dienstenkosten en heffingen zijn voor rekening van de afnemer.

De gemiddelde gerealiseerde commodityprijs voor inkoop aardgas nam in de periode 2013-2016 af, in de jaren 2017 en 2018 toe en in 2019 weer af. De commodityprijs voor inkoop en verkoop elektriciteit liet een overeenkomstige ontwikkeling zien. De laatste twee jaren was echter de stijging bij verkoop en inkoop elektriciteit groter dan de stijging bij inkoop aardgas. Hierdoor werd de spark spread gunstiger en verbeterde het exploitatie resultaat om met de aardgas-wkk elektriciteit te produceren voor de verkoop maar ook voor eigen gebruik. Dit leidde tot een toename van de gebruiksduur van de wkk's in 2018 met ruim 3\% en in 2019 met ruim 4\% (hoofdstuk 5). Het voorgaande resulteerde in toename van de elektriciteitsproductie met wkk, het aardgasverbruik en de verkoop van elektriciteit. Het gebruik van de wkk's wordt begrensd vanuit de warmtevraag op de bedrijven met als gevolg dat door toename van de elektriciteitsvraag door intensivering van de belichting ook de inkoop van elektriciteit toenam.

\section{Netto-energiekosten}

Na een lichte toename in 2018 zijn de netto-energiekosten in 2019 gedaald tot gemiddeld circa $€ 7$ per $\mathrm{m}^{2}$ (figuur 2.6). In 2019 zijn zowel de kosten voor de inkoop als de opbrengsten van de verkoop gedaald. De daling bij de inkoop was iets sterker dan de daling bij de verkoop, waardoor de nettoenergiekosten in 2019 licht zijn gedaald.

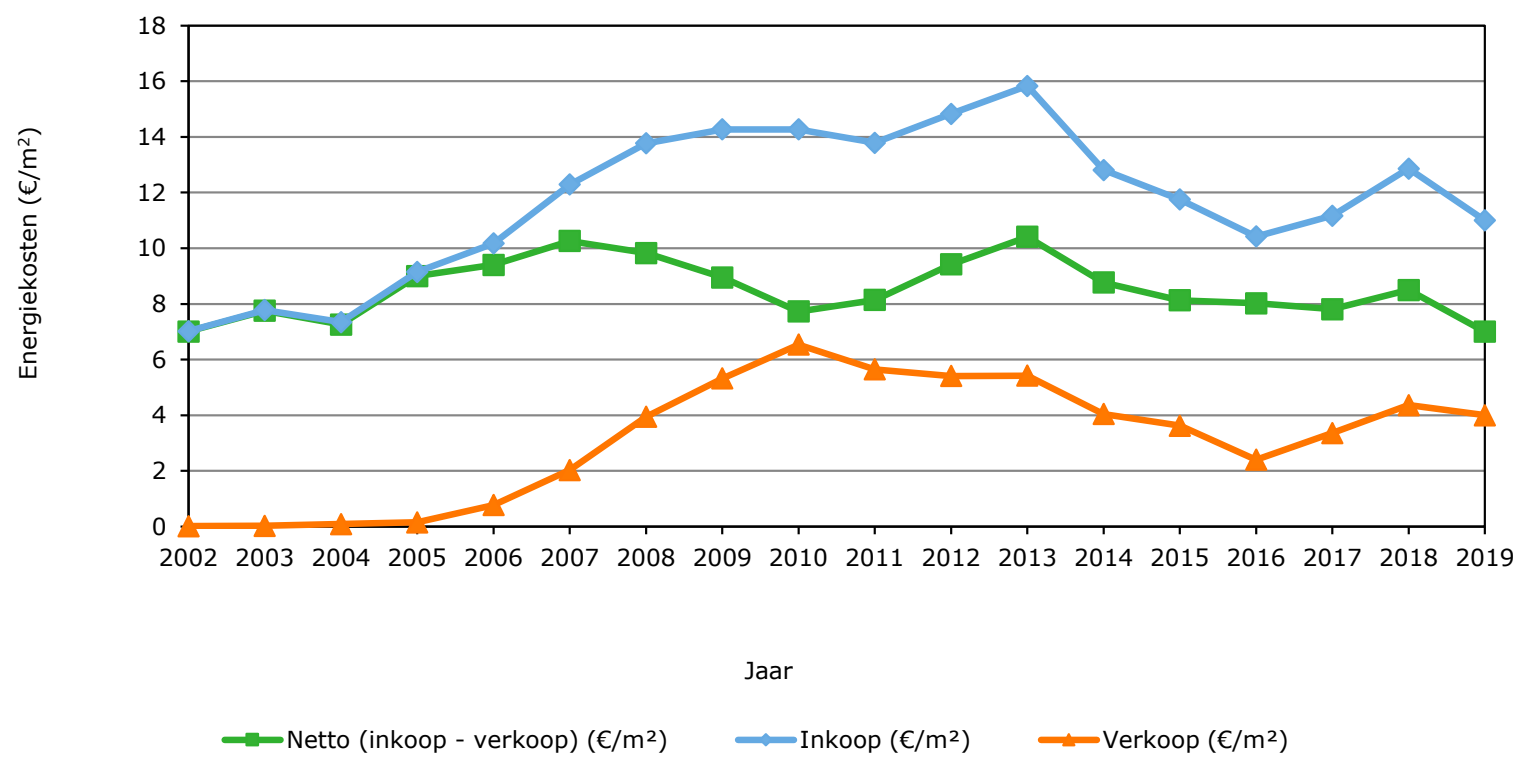

Figuur 2.6 Gemiddelde energiekosten glastuinbouw $\left(€ / \mathrm{m}^{2}\right)$ a)

a) Cijfers 2019 voorlopig.

Bron: Bedrijveninformatienet van Wageningen Economic Research.

Over een langere periode bezien lieten de netto-energiekosten in de periode 2010-2013 een toename zien. Dit kwam door toename van de inkoopkosten en een daling van de opbrengsten uit verkoop. In de periode 2013-2017 namen de nettokosten weer af. Dit kwam doordat de daling van de kosten voor inkoop een groter effect had vergeleken met de verdere daling van de opbrengsten. In 2018 namen de netto-energiekosten toe en in 2019 weer af. In 2019 lagen de netto-energiekosten op hetzelfde niveau van in 2002 en (nominaal) onder het niveau van alle jaren tussen 2002 en 2019. In reële prijzen liggen de netto-energiekosten in 2019 circa 20\% onder het niveau van 2002. 


\section{Exploitatieresultaat wkk}

Door de gunstige spark spread voor zowel de productie van elektriciteit voor de verkoop als voor eigen gebruik was het exploitatieresultaat in de jaren 2017, 2018 en 2019 vooral voor bestaande wkk's gunstig. Voor de jaren na 2019 zijn er door een deel van de bedrijven reeds gunstige aardgasprijzen voor de inkoop en elektriceitsprijzen voor de verkoop gecontracteerd. Hierdoor zal de spark spread en het exploitatieresultaat voor wkk voorlopig gunstig blijven. Dit remt het gebruik van energievoorzieningsopties zonder $\mathrm{CO}_{2}$-emissie. Hiernaast zijn bedrijven bezig vervangingsinvesteringen af te wegen. Hierbij speelt met name de inzet voor productie van elektriciteit voor eigen consumptie een rol. Ook dit is van invloed op de transitie naar een energievoorziening zonder $\mathrm{CO}_{2}$-emissie. Hier wordt nader op ingeaan in de reflectie in hoofdstuk 5.

\subsection{Warmte- en elektriciteitsgebruik}

\section{Totaal energiegebruik}

Het totaal energiegebruik van de glastuinbouw liet in de periode 2010-2014 een dalende trend zien, in de periode 2014-2018 bleef het min of meer stabiel maar in 2019 was er een toename van 6\%. De toename in 2019 hing vooral samen met de toename van het areaal. Het totaal energiegebruik lag in 2019 wel ruim onder het niveau van voor 2014, het jaar waarna de daling van het energiegebruik wijzigde in een stijging. Deze ontwikkeling hing samen met een toenemende energievraag door intensivering, vermindering van de energievraag door extensivering en energiebesparing, de omvang van de sector (ha) en verschillen in buitentemperatuur tussen de jaren (paragraaf 2.5).

De energievraag wordt in beginsel niet beïnvloed door de energievoorziening of de herkomst van de energie (fossiel of duurzaam). ${ }^{6}$ Door uit te gaan van het energiegebruik per $\mathrm{m}^{2}$ na correctie voor buitentemperatuur, hebben veranderingen in areaal en verschillen in buitentemperatuur geen invloed en resteert de invloed van intensivering, extensivering en energiebesparing op het energiegebruik per $\mathrm{m}^{2}$.

\section{Energiegebruik per $\mathrm{m}^{2}$}

Uit figuur 2.7 blijkt dat het gemiddelde energiegebruik per $\mathrm{m}^{2}$ na correctie voor de buitentemperatuur over de periode 2000-2014 daalde (-10\%) en in de periode 2014-2018 weer toenam (+7\%). In 2019 trad een daling op met $3 \%$ en bedroeg het totaal energiegebruik per $\mathrm{m}^{2}$ na temperatuurcorrectie $1,24 \mathrm{GJ}$ per $\mathrm{m}^{2}$. Dit is gelijk aan het gemiddelde niveau in de jaren 2011 tot en met 2014. In 2017 en 2018 lag het energiegebruik per $\mathrm{m}^{2}$ iets hoger dan in 2019.

\section{Warmte en elektriciteit}

Het energiegebruik per $\mathrm{m}^{2}$ na correctie voor de buitentemperatuur is in figuur 2.6 vanaf 2006 opgesplitst in warmte en elektriciteit. Uit de figuur blijkt dat de toename van het totaal energiegebruik per $\mathrm{m}^{2}$ kas in de periode 2014-2018 (+7\%) samengaat met een beperkte groei van het warmtegebruik $(+2 \%)$ en een sterke groei van de elektriciteitsconsumptie $(+29 \%$.) In 2019 nam de warmtevraag af $(-4 \%)$ en de elektriciteitsvraag wederom toe $(+5 \%)$. In 2019 bestond circa $74 \%$ van het totale energiegebruik uit warmte en circa $26 \%$ uit elektriciteit. In 2010 was dit $90 \%$ en $10 \%$. Er is dus een verschuiving opgetreden van warmte- naar elektriciteitsvraag.

De groei van de elektriciteitsconsumptie per $\mathrm{m}^{2}$ komt hoofdzakelijk door intensivering in de vorm van groeilicht. Er werd meer areaal belicht en de intensiteit $\left(\mathrm{W}_{\mathrm{e}} / \mathrm{m}^{2}\right)$ nam toe. Daarnaast doen het gebruik van duurzame energiebronnen, mechanisatie, automatisering en verdere optimalisatie van het kasklimaat de elektriciteitsconsumptie toenemen (Van der Velden en Smit, 2013).

\footnotetext{
6 De $\mathrm{CO}_{2}$-voorziening met rookgassen uit aardgas in perioden zonder warmtevraag (zomerstook) is hierop een uitzondering
} 


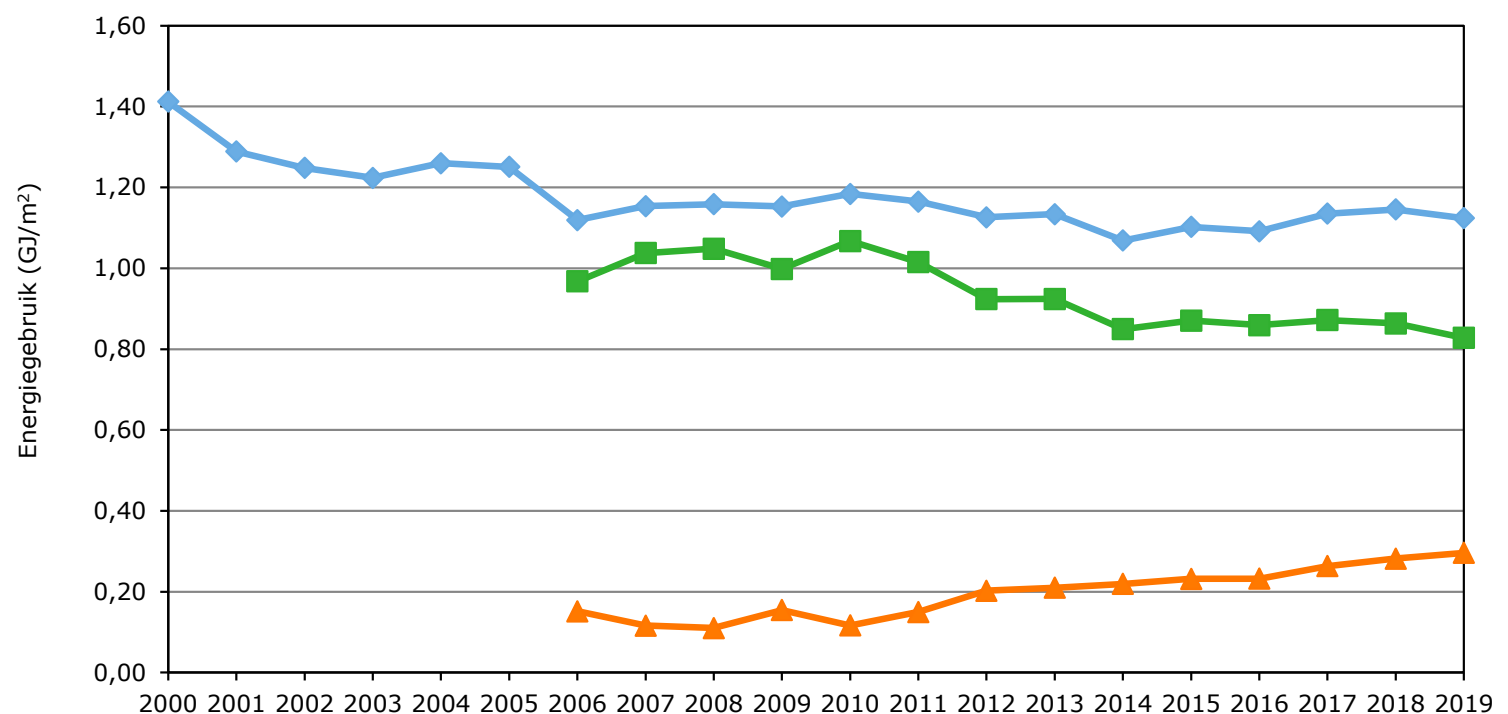

Jaar

$\sim$ Energie totaal $\left(\mathrm{GJ} / \mathrm{m}^{2}\right) \quad$ W Warmte $\left(\mathrm{GJ} / \mathrm{m}^{2}\right) \quad$ Elektriciteit $\left(\mathrm{GJ} / \mathrm{m}^{2}\right)$

Figuur 2.7 Gemiddeld energiegebruik per $\mathrm{m}^{2}$ gecorrigeerd voor de buitentemperatuur a) a) Cijfers 2019 voorlopig.

De ontwikkeling van de energieconsumptie per $\mathrm{m}^{2}$ is het saldo-effect van intensivering, extensivering en energiebesparing. Uit de toename in de periode 2014-2018 kan worden afgeleid dat het totaaleffect van intensivering in deze periode groter was dan het effect van extensivering plus energiebesparing. De intensivering van het elektriciteitsgebruik had hierbij een groter effect dan de mutatie van het warmtegebruik. In 2019 was het effect van intensivering kleiner dan het effect van extensivering. Hierbij gold dat het warmtegebruik per $\mathrm{m}^{2}$ sterker afnam, dan het elektriciteitsgebruik per $\mathrm{m}^{2}$ steeg.

\subsection{Energievoorziening zonder $\mathrm{CO}_{2}$-emissie}

In de paragrafen 2.2 en 2.5 is de ontwikkeling van de $\mathrm{CO}_{2}$-emissie beschreven. In deze paragraaf wordt de ontwikkeling van de energievoorziening zonder $\mathrm{CO}_{2}$-emissie (c.q. zonder direct aardgasverbruik) van de glastuinbouw behandeld. Op basis van de IPCC-methode zijn dit de volgende drie energievoorzieningen:

- gebruik duurzame energie (productie en inkoop),

- inkoop elektriciteit (niet-duurzaam) en

- inkoop van warmte (niet-duurzaam).

In figuur 2.7 zijn de aandelen van deze drie energievoorzieningen in het totale energiegebruik vanaf 2010 weergegeven. In het totale energiegebruik is de verkoop van energie en dus ook de verkoop vanuit de wkk's op aardgas in mindering gebracht. In de figuur is zichtbaar dat het aandeel duurzame energie is gegroeid van nagenoeg nihil in 2000 tot ruim $9 \%$ in 2019 . Het aandeel inkoop van warmte (niet-duurzaam) van buiten de sector nam af van $11 \%$ in 2000 tot onder de $3 \%$ in 2019. De laatste jaren is deze daling sterker door de toename van de fractie duurzaam in het gebruik van restwarmte. De inkoop van elektriciteit (niet-duurzaam) vertoond een iets grilliger verloop. Over de hele periode vanaf 2010 is er een duidelijke toename van 4 tot $10 \%$. Het jaar 2017 is hierop een uitzondering. Dit kwam door de grotere hoeveelheid duurzame elektriciteit die in dat jaar werd ingekocht, terwijl de inkoop van warmte van derden stabiliseerde en de totale energieconsumptie daalde. Inkoop van duurzame elektriciteit telt mee in het aandeel duurzame energie en niet bij inkoop elektriciteit. 


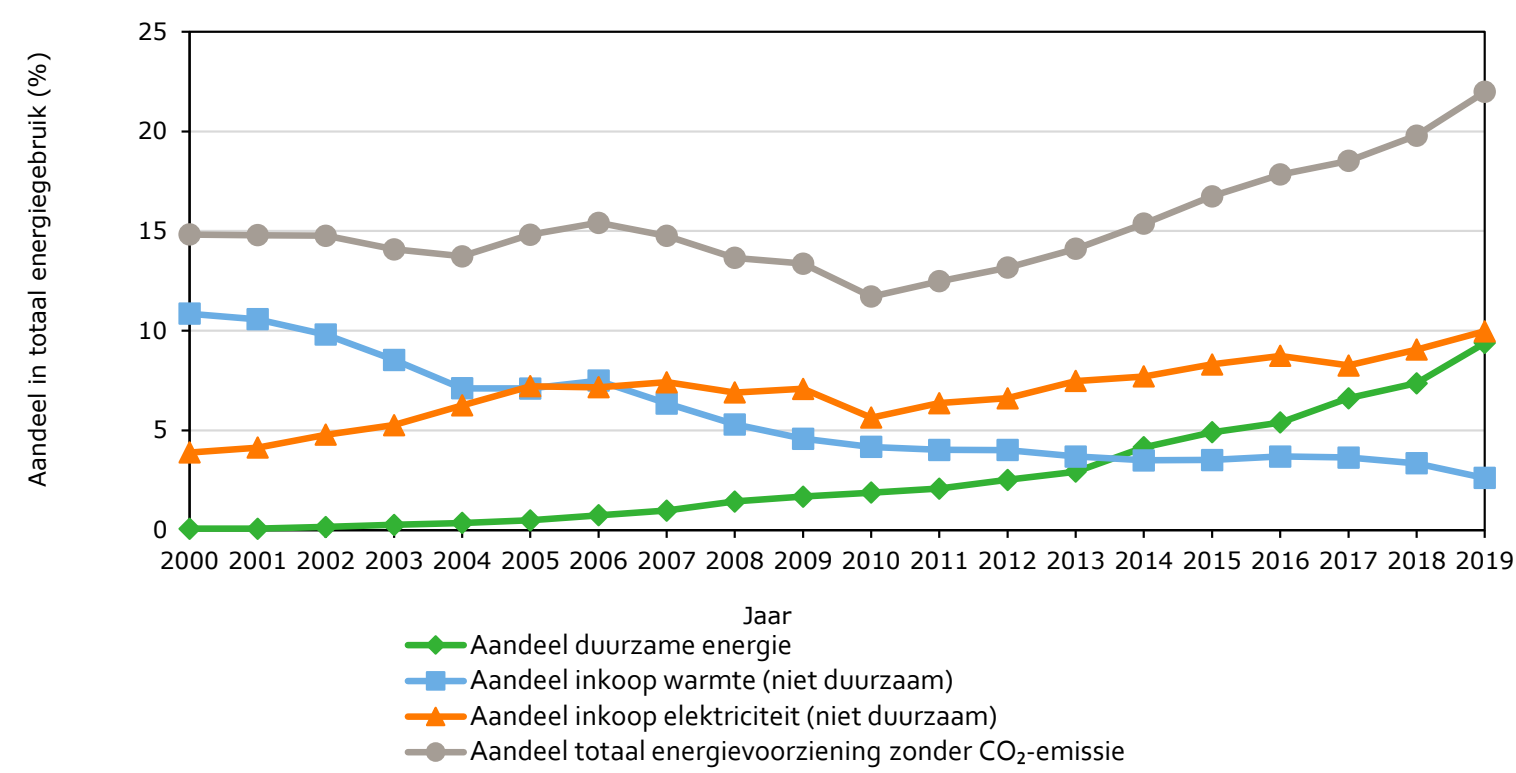

Figuur 2.8 Aandeel energievoorziening zonder $\mathrm{CO}_{2}$-emissie in totaal energiegebruik a) a) Cijfers 2019 voorlopig.

In figuur 2.7 is ook de ontwikkeling van het totale aandeel van de energievoorziening zonder $\mathrm{CO}_{2}$-emissie vanaf 2000 zichtbaar. De periode 2000-2004 vertoont een afname, vooral door daling van de inkoop van warmte. Deze periode werd gevolgd door een groei van de energievoorziening zonder $\mathrm{CO}_{2}$-emissie in de jaren 2005 en 2006. In deze jaren steeg het gebruik van duurzame energie en inkoop elektriciteit en stabiliseerde de inkoop van warmte van derden, terwijl de totale energieconsumptie daalde. De periode 2006-2010 toont wederom een daling. Dit kwam vooral door de opkomst van wkk, verdere daling van de inkoop van warmte van derden en daling van de inkoop elektriciteit.

Over de gehele periode 2010-2019 was er een duidelijke toename van het aandeel energievoorziening zonder $\mathrm{CO}_{2}$-emissie. In 2010 bedroeg het totale aandeel $12 \%$ en in 2019 is dit toegenomen tot $22 \%$. Dit is een toename van meer dan $80 \%$ in 9 jaar. De toename komt vooral door de groei van duurzame energie. Ook de toename van de inkoop van elektriciteit had een positieve invloed. Het aandeel inkoop van warmte daalde. Het voorgaande betekent ook dat de glastuinbouw vanaf 2010 geleidelijk minder afhankelijk is geworden van het directe verbruik van aardgas, maar in 2019 voor haar energievoorziening toch nog grotendeels (78\%) afhankelijk is van het directe verbruik van aardgas. 


\section{Analyse duurzame energie}

\section{$3.1 \quad$ Inleiding}

Glastuinbouwbedrijven zijn met partners actief om meer energie uit duurzame energievoorzieningen toe te passen. Dit komt voort uit eigen duurzaamheidsmotieven, het streven te voldoen aan duurzaamheidseisen van klanten of omdat het duurzame alternatief bedrijfseconomisch aantrekkelijker is dan de gangbare fossiele energiebron. In de volgende paragrafen komen achtereenvolgens de toepassing en de ontwikkeling van de afzonderlijke duurzame energiebronnen, de bedrijfsstructuur, de warmtedekking, de $\mathrm{CO}_{2}$-emissiereductie en de inkoop van externe $\mathrm{CO}_{2}$ aan de orde. Externe $\mathrm{CO}_{2}$ is geen duurzame energie, maar wel nodig om gebruik van duurzame warmte en inkoop van warmte door de glastuinbouw mogelijk te maken.

\subsection{Bronnen van duurzame energie}

\subsubsection{Toepassing}

De Nederlandse glastuinbouw paste in 2019 zes bronnen van duurzame energie toe. Aardwarmte was met $42 \%$ de voornaamste bron (tabel 3.1 en figuur 3.2). Daarna volgden inkoop duurzame warmte ( $24 \%$ ) en duurzame elektriciteit (14\%), biobrandstoffen $(11 \%)$, zonne-energie $(8 \%)$ en inkoop duurzaam gas $(<1 \%)$ (tabel 3.1$)$.

Tabel 3.1 Toepassing van duurzame energievormen in de Nederlandse glastuinbouw in 2018 v)

\begin{tabular}{|c|c|c|c|c|c|c|c|}
\hline \multirow[t]{2}{*}{ Duurzame energievorm } & Bedrijven a) & Areaal a) & Gemiddeld & Warmte & Elektriciteit & Totaal & Aandeel \\
\hline & aantal & ha & ha per bedrijf & PJ & TWh & PJ & $\%$ \\
\hline Aardwarmte b) & 86 & 943 & 11,0 & 4,2 & - & 4,2 & 42 \\
\hline - warmte & 37 & 163 & 4,4 & 0,9 & - & 0,9 & 9 \\
\hline - warmte en elektriciteit & 6 & 45 & 7,4 & 0,2 & $<0,01$ & 0,2 & 2 \\
\hline - elektriciteit & 101 & 358 & 3,5 & - & 0,01 & 0,0 & 0 \\
\hline - warmte & 62 & 214 & 3,4 & 0,8 & - & 0,8 & 8 \\
\hline Inkoop duurzaam gas & $-c)$ & $-c)$ & $-c)$ & $<0,1$ & - & 0,0 & $<1$ \\
\hline Inkoop duurzame elektriciteit & - c) & - c) & $-c)$ & - & 0,37 & 1,3 & 13 \\
\hline Totaal d) & 304 & 2.143 & 7,1 & 8,6 & 0,39 & 10,0 & 100 \\
\hline
\end{tabular}

a) Peildatum eind 2019; b) Cijfers aardwarmte zijn afkomstig van Dutch Association of Geothermal Operators (DAGO); c) Cijfers niet bekend.

d) Als meerdere vormen van duurzame energie op een bedrijf worden toegepast is dat eenmaal meegenomen in het totaal; v) Voorlopige cijfers.

In 2019 is het totale gebruik van duurzame energie gegroeid met bijna 37\%. Dit de grootste stijging van de hoeveelheid sinds de monitor van duurzame energie in het jaar 2000 werd gestart. De groei was het saldo van nieuwe projecten, aanpassing van bestaande projecten, projectbeëindiging en verandering van de inkoop. Vooral de hoeveelheden inkoop van duurzame warmte en de inzet van aardwarmte en biobrandstof namen toe (figuur 3.1). De toepassing van zelf opgewekte zonneelektriciteit groeide ook, maar was qua hoeveelheid nog beperkt. De inkoop van duurzaam gas en de inzet van zonnewarmte waren stabiel. De inkoop van duurzame elektriciteit daalde ten opzichte van 2018. De achtergronden bij deze ontwikkelingen komen in paragraaf 3.2.2. aan bod. In totaal werd er 
in 2019 door de glastuinbouw 10,0 PJ duurzame energie toegepast. Het gebruik van duurzame energie is hiermee sinds 2015 meer dan verdubbeld (figuur 2.4). De toegepaste duurzame energie bestond voor $86 \%$ uit warmte en voor $14 \%$ uit elektriciteit (tabel 3.1). De duurzame warmte wordt al jaren vooral door de sector zelf geproduceerd (in 2019 72\%) en duurzame elektriciteit wordt vooral buiten de sector ingekocht (in 2019 96\%). Wel is het aandeel van de toegepaste duurzame energie dat buiten de sector is aangekocht in 2019 met ruim 30\% sterk gegroeid.

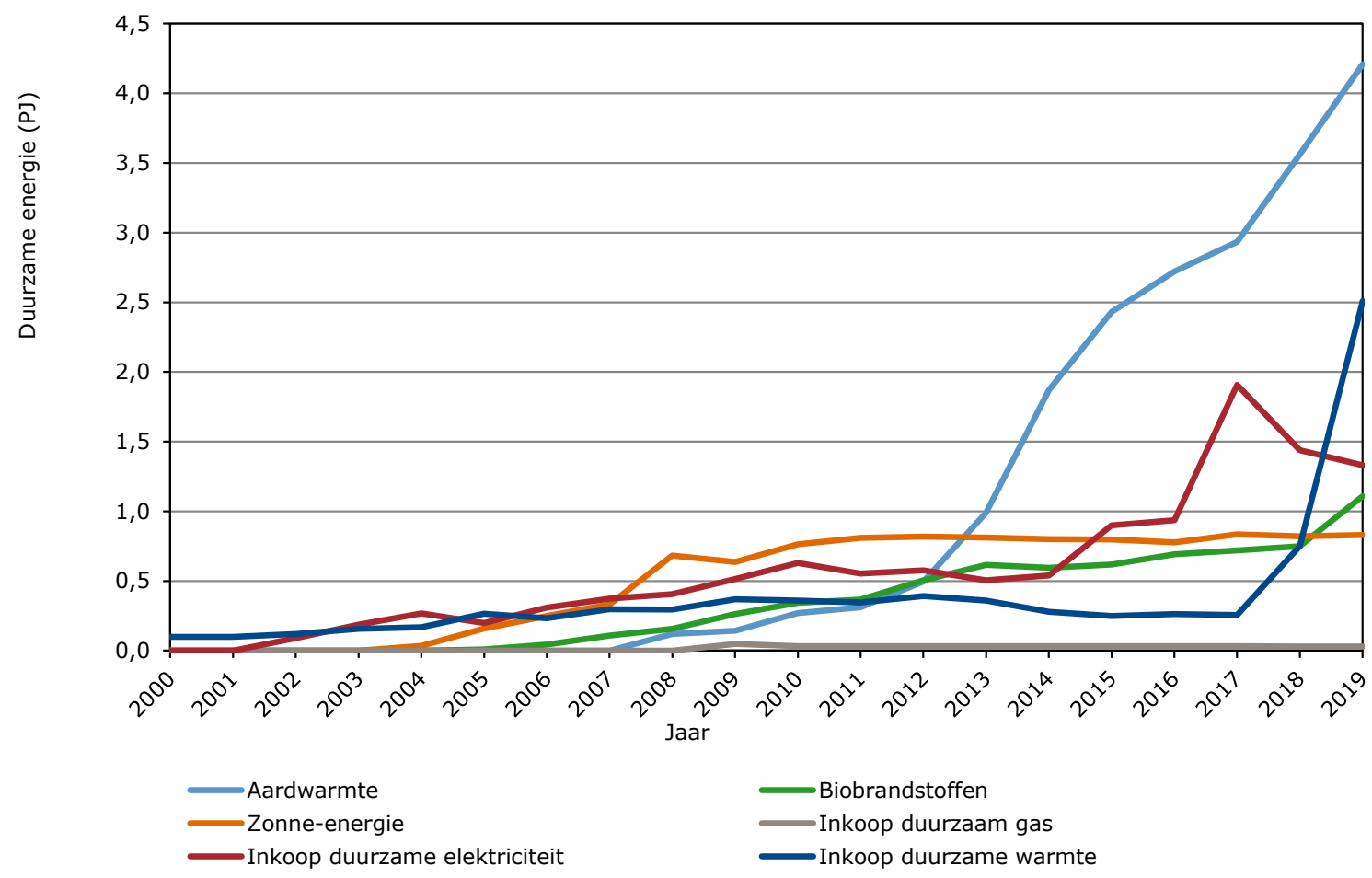

Figuur 3.1 Ontwikkeling van het gebruik van duurzame energie in de glastuinbouw per bron per jaar $v$ )

v) Cijfers 2019 voorlopig.

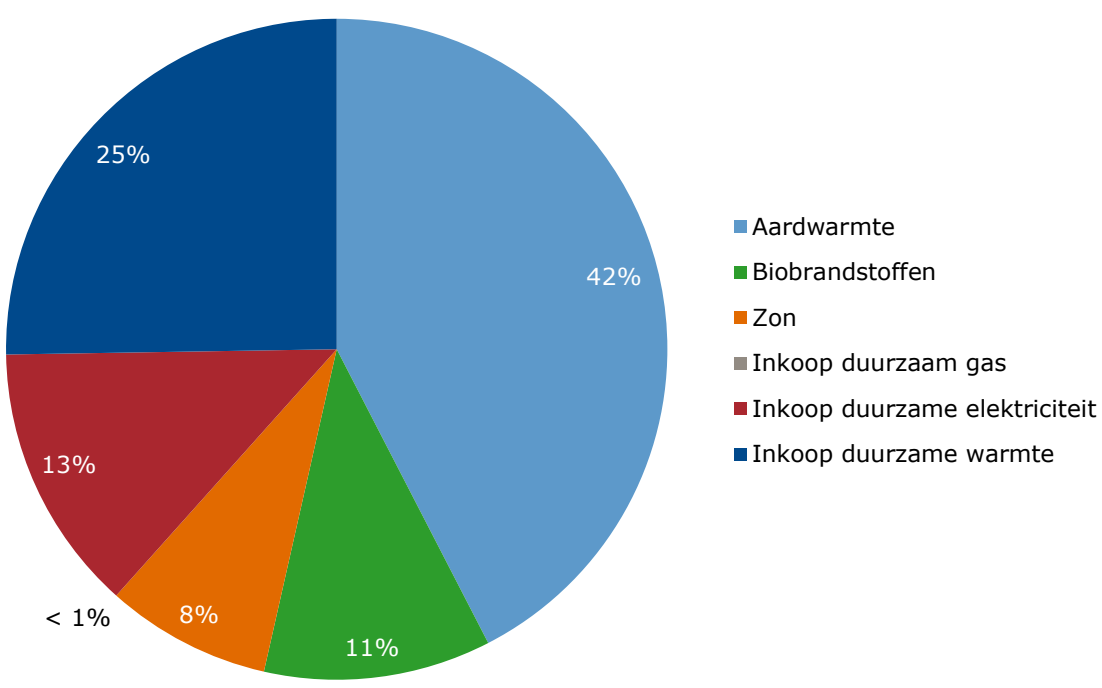

Figuur 3.2 Aandeel gebruik van het van duurzame energie in de glastuinbouw in 2019 per bron v) v) Cijfers voorlopig. 


\subsubsection{Ontwikkeling per bron}

\section{Aardwarmte}

In 2019 steeg de hoeveelheid toegepaste geothermie die door de glastuinbouw zelf werd geproduceerd met $42 \%$. Dit kwam doordat er nieuwe projecten in gebruik werden genomen en bestaande projecten meer produceerden. Die grotere productie kwam doordat bij bestaande projecten de uitkoeling van de bron verder geoptimaliseerd werd, er meer areaal werd aangesloten en door ervaring productieonderbrekingen verminderden. Hierdoor nam de bedrijfstijd toe.

Eind 2019 waren er in de glastuinbouw 24 aardwarmtedoubletten gerealiseerd. Het aantal glastuinbouwbedrijven met aardwarmte nam in 2019 toe naar 86 . Hiervan waren er 65 risicodragend deelnemer (exploitant) en 21 afnemer. Het areaal glastuinbouw groeide van 741 naar 943 ha. Hiermee werd er in 2019 op bijna 10\% van het totaal areaal glastuinbouw in Nederland door de sector geproduceerde aardwarmte toegepast. Op ruim $80 \%$ van het areaal met aardwarmte werd groente geteeld. Dit hangt onder meer samen met de warmtevraag bij groenteteelt in combinatie met de schaalgrootte van deze bedrijven. Op 94\% van het areaal met aardwarmte wordt aardwarmte gebruikt die door deze glastuinbouwbedrijven zelf is gewonnen, op de overige $6 \%$ wordt deze ingekocht van andere glastuinbouwbedrijven.

In 2019 waren niet alle projecten het volledige jaar of met het ontwerpvermogen in bedrijf. Dit kwam doordat nieuwe projecten in de loop van het jaar werden opgestart en bestaande projecten te maken hadden met onderhoud, storingen en andere onderbrekingen. De gemiddelde inzet van aardwarmte per $\mathrm{m}^{2}$ kas was met 0,45 GJ (circa $14 \mathrm{~m}^{3}$ a.e.) in 2019 iets lager dan in 2018. Dit kwam doordat het areaal met aardwarmte harder steeg dan de hoeveelheid toegepaste warmte.

Er zijn ook aardwarmteprojecten in Nederland waarvan de exploitatie in handen is van partijen buiten de glastuinbouw. De duurzame energie aangekocht vanuit deze projecten is meegenomen bij 'Inkoop van duurzame energie'.

\section{Zonne-energie}

De toepassing van herwonnen zonnewarmte was in 2019 stabiel. Er kon door relatief veel zoninstraling en hoge temperaturen veel warmte gewonnen worden. Echter, het was door diezelfde hoge instraling en warmte een opgave om de herwonnen warmte ook toe te passen. Dit werd versterkt door de warmte beschikbaar uit het eveneens warme jaar 2018.

In totaal werd zonnewarmte toegepast door 62 bedrijven met een gezamenlijk glasareaal van 214 ha. Herwinning zonnewarmte ontwikkelt zich al jaren alleen nog bij bedrijven waarbij koude nodig is voor koeling van de teelt. De zonnewarmte werd vooral toegepast bij plantenbedrijven (131 ha), op afstand gevolgd door bloemen (47 ha) en groente ( $36 \mathrm{ha}$ ). Bij bloemen waren alle bedrijven met herwinning van zonnewarmte uit grondkoeling te vinden, hoofdzakelijk bij de gewassen alstroemeria, amaryllis en freesia. Bij planten betreft het hoofdzakelijk de teelt van phalaenopsis. Op circa de helft van het totale areaal van deze vier gewassen wordt koeling gecombineerd met herwinning van zonnewarmte. Ook passen enkele bedrijven met uitgangsmateriaal herwinning van zonnewarmte toe.

In 2019 groeide het aantal bedrijven met winning van elektriciteit via fotovoltaïsche cellen (zon PV) verder door. De toepassing groeide door het toegenomen vermogen en door de grote hoeveelheid zonlicht in de lente en zomer met meer dan 50\%. Bij toepassing van duurzame elektriciteit vanuit eigen productie door de glastuinbouw is zonne-elektriciteit sinds 2017 de voornaamste bron. De gewonnen elektriciteit werd voor circa driekwart toegepast op de bedrijven en de rest werd verkocht. Zonne-elektriciteit groeit vooral doordat bedrijven bij hun investeringen in duurzame energie gebruik kunnen maken van stimuleringsregelingen. Het aandeel van zon-elektrische energie in de totale hoeveelheid toegepaste, duurzame elektriciteit blijft ondanks de groei nog zeer beperkt (ruim $2 \%$ ). Deze beperkte hoeveelheid komt enerzijds doordat het kasoppervlak van glastuinbouwbedrijven zonlicht moet kunnen doorlaten voor de groei van de gewassen en daarmee het oppervlak waar de glastuinbouw zonnepanelen kan plaatsen beperkt is. Anderzijds zit gemiddeld de elektriciteitsvraag van de glastuinbouw vooral in perioden waarin zonlicht beperkt of afwezig is (winter en nacht). 


\section{Biobrandstof}

Het aantal glastuinbouwbedrijven waar in 2019 biobrandstof werd toegepast, steeg naar 43 en het areaal naar 208 ha. Hiervan gebruikte 6 bedrijven met een gezamenlijk areaal van 45 ha biobrandstof in een wkk. Nieuw was een project van 3 bedrijven met een gezamenlijk areaal van 20 ha waar warmte en $\mathrm{CO}_{2}$ uit de rookgassen werden toegepast. Van het areaal met biobrandstof in ketels was 97 ha te vinden bij de teelt van groenten, 85 ha bij planten en 25 ha bij bloemen. Hout is al jaren de voornaamste biobrandstof voor de glastuinbouw. Er gebruikten 40 bedrijven resthout uit industrie of snoeihout uit groenbeheer als brandstof. Drie bedrijven haalden hun biobrandstof uit vergisting en zetten deze met een bio-wkk om naar warmte en elektriciteit. In 2019 namen 40 glastuinbouwbedrijven deel aan de exploitatie van een installatie op biobrandstof. Vanuit deze projecten werd aan 3 andere glastuinbouwbedrijven warmte geleverd.

De combinatie van een onzekere en relatief hoge biobrandstofprijs en een relatief lage aardgasprijs leidt vooral bij bestaande projecten steeds vaker tot stevige bedrijfseconomische afwegingen tussen de inzet van biobrandstof en de inzet van aardgas met wkk. Per saldo steeg de toepassing van energie uit biobrandstoffen in 2019 met 47\%. Deze forse stijging kwam doordat er nieuwe relatief grote projecten in gebruik zijn genomen en de draaiuren van bestaande installaties stegen. Er zijn ook biobrandstofprojecten waarvan de exploitatie in handen is van partijen buiten de glastuinbouw. De duurzame energie aangekocht vanuit deze projecten is meegeteld bij 'Inkoop van duurzame energie'.

\section{Inkoop van duurzame energie}

Door de glastuinbouw wordt naast eigen productie ook duurzame elektriciteit, duurzame warmte en duurzaam gas ingekocht. De duurzaamheid van ingekochte duurzame elektriciteit en duurzaam gas uit openbare netten wordt met Garanties van Oorsprong (GVO) gewaarborgd. Glastuinbouwbedrijven kopen duurzame elektriciteit in vanuit eigen motieven of om te voldoen aan regelingen en keurmerken waarbij een mate van duurzaamheid een vereiste is.

De inkoop van duurzame elektriciteit daalde ten opzichte van 2018. Er werd in 2019370 miljoen kWh ingekocht. De hogere prijs van duurzame elektriciteit ten opzichte van gangbare elektriciteit speelt hierbij een rol, maar ook de groei van eigen opwekking met zonnepanelen.

Inkoop van duurzame warmte vindt plaats vanuit centrale en decentrale projecten. Bij centrale inkoop betreft het een deel van de restwarmte dat duurzaam wordt opgewekt met bijstook van biobrandstof in centrales. Bij decentrale projecten wordt op kleinere schaal lokaal duurzame warmte uit biobrandstoffen geleverd aan glastuinbouwbedrijven door exploitanten van installaties van buiten de sector.

De inkoop van duurzame warmte groeide sterk door van bijna 0,7 PJ in 2018 naar 2,5 PJ in 2019. Hiermee was bijna de helft van alle warmte ingekocht bij derden door tuinders van duurzame oorsprong. Deze groei kwam enerzijds door de ingebruikname van nieuwe, relatief grote, decentrale installaties in de directe nabijheid van glastuinbouwbedrijven en anderzijds door verdere verhoging van de duurzame fractie bij centrale warmtelevering. De groei van de inkoop vanuit de decentrale projecten kwam door ingebruikname van 3 aardwarmtebronnen en 2 biobrandstofinstallaties door partijen buiten de glastuinbouw met warmteverkoop aan de glastuinbouw op gebiedsniveau. Hierdoor groeide het areaal met decentrale inkoop duurzame warmte in 2019 van 68 naar 421 ha. Duurzame warmte ingekocht bij derden was in 2019 voor ruim de helft afkomstig uit aardwarmte en voor iets minder dan de helft uit biobrandstof.

Duurzaam gas betreft biogas dat is geproduceerd en geconverteerd naar een standaardkwaliteit, waardoor gas met GVO via het aardgasnet gekocht kan worden door de eindverbruiker. De aankoopmotieven voor de inkoop van duurzaam gas zijn globaal gelijk aan die voor de inkoop van duurzame elektriciteit. De kosten voor de inkoop van duurzaam gas zijn in vergelijking met duurzame elektriciteit hoog, hierdoor bleef in 2019 net als eerdere jaren het gebruik ervan zeer beperkt.

Totaal aardwarmte en biobrandstof

Projecten met winning van aardwarmte en met gebruik van biobrandstof kunnen worden geëxploiteerd door glastuinbouwbedrijven maar ook door partijen buiten de glastuinbouw. Bij exploitatie door 
derden is er inkoop duurzame warmte door de glastuinbouw. In totaal werd er in 2019 door de glastuinbouw 5,6 PJ aardwarmte gebruikt. Hiervan werd 1,4 PJ bij derden ingekocht. Het totaal gebruik van warmte afkomstig uit biobrandstof bedroeg in 2019 2,2 PJ. Hiervan werd 1,1 PJ bij derden ingekocht. Toegepaste aardwarmte werd dus voor ongeveer een kwart en warmte uit biobrandstof voor ongeveer de helft bij derden ingekocht.

Totaal areaal

Het totaal areaal met gebruik van duurzame energie bedraagt in 2019 ruim 2.100 ha (tabel 3.1). Dit is exclusief inkoop duurzame elektriciteit, duurzaam gas en centraal geleverde duurzame warmte. Dit betekent dat in 2019 meer dan 22\% van het totaal areaal glastuinbouw gebruikmaakt van duurzame energie. Het areaal met duurzame warmte bedraagt circa 1.800 ha. Dit betekent dat circa $19 \%$ van het areaal gebruik maakt van aardwarmte, biobrandstof, zonnewarmte of decentrale inkoop van duurzame warmte.

\section{Ontwikkelingen}

Projecten met duurzame energie worden de laatste jaren vooral in samenwerking ontwikkeld: samenwerking tussen glastuinbouwbedrijven onderling, maar ook met partijen van buiten de sector zoals leveranciers van installaties, energiebedrijven en andere externe exploitanten.

Tot 2010 kwamen duurzame energieprojecten vooral tot stand door inspanningen van tuinders die als pionier gekarakteriseerd konden worden. In de periode hierna tot circa 2015 werden duurzame energieprojecten steeds vaker gerealiseerd door het gezamenlijk optrekken van glastuinbouwbedrijven gevestigd in elkaars nabijheid. Hiermee konden grotere, efficiëntere projecten worden gerealiseerd en werden projectrisico's beter beheersbaar. Na 2015 zijn met dezelfde motieven en de kansen die duurzame energie voor partijen buiten de glastuinbouw bieden de volgende stappen gezet.

Glastuinbouwbedrijven realiseerden met partners van buiten de sector gezamenlijk projecten. Hierbij zijn er projecten waarbij zowel de betrokken tuinders als de derde partij risicodragend deelnemen. Ook zijn er projecten waarbij tuinders zich beperken tot aankoopafspraken en de exploitatie volledig in handen is van de partij van buiten de sector. Mede door onderlinge samenwerking en betrokkenheid van partijen van buiten de sector konden projecten gerealiseerd worden met een groter vermogen. In combinatie met het aanleggen van warmtedistributie in gebieden kon het areaal met duurzame energie verder doorgroeien. De groei van het areaal met duurzame energie werd in 2019 globaal 5\% gerealiseerd door individuele glastuinbouwbedrijven en meer dan $50 \%$ door bedrijven die duurzame warmte van partners van buiten de sector aankopen. De resterende $45 \%$ van het nieuwe areaal met duurzame energie werd gerealiseerd door gezamenlijk optrekken van meerdere tuinders met in meer of mindere mate betrokkenheid van partners van buiten de sector. Hoe deze ontwikkeling uitwerkt op de totale hoeveelheid wordt dit in figuur 3.4 geïllustreerd. De ontwikkeling van het areaal met duurzame energie is in figuur 3.5 zichtbaar gemaakt.

Een ander aspect dat de ontwikkeling van de toepassing van duurzame energie beïnvloedt, zijn de bedrijfseconomische mogelijkheden in vergelijking met gangbare energievoorzieningen. De toepassing van duurzame energie is in de glastuinbouw hoofdzakelijk warmte (86\%). Duurzame warmte concurreert in economisch opzicht met gangbare bronnen. In de glastuinbouw zijn dit vooral de aardgas-wkk's. Vanaf 2017 is door de verbeterde spark spread het bedrijfseconomisch voordeel van aardgas-wkk ten opzichte van duurzame bronnen versterkt (hoofdstuk 4). Dit komt door de relatief lage gasprijs in combinatie met financieringsverplichtingen voor bestaande wkk's. Als in 2019 duurzame warmtebronnen door ondernemers op enkel economische gronden werden afgewogen tegen aardgas-wkk, dan waren uitkomsten voor de duurzame warmtebronnen vaker ongunstig. Omdat bij de start van de projecten andere bedrijfseconomische veronderstellingen actueel waren, ook het aspect van duurzaamheid meetelt en er naast de warmte die aardgas-wkk kan produceren nog meer warmtevraag is, zijn er wel projecten gerealiseerd. Dit resulteerde dan vaak in een verschuiving van eigen productie met aardgas-wkk naar gebruik van duurzame warmte, inkoop van elektriciteit en inkoop van externe $\mathrm{CO}_{2}$. In de actuele situatie lopen bedrijven die duurzame warmtebronnen willen exploiteren tegen grenzen aan als zij het perspectief van voldoende bedrijfseconomisch rendement beoordelen en dit remt verdere groei van duurzame warmte in de glastuinbouw. 


\subsubsection{Productie, inkoop, verkoop en consumptie}

De productie, inkoop, verkoop en consumptie van duurzame energie in 2019 is samengevat in figuur 3.3. Deze balans laat zien dat de consumptie van duurzame energie voor bijna twee derde gedekt werd door eigen productie en voor ruim een derde werd ingekocht bij partijen buiten de sector. De door de glastuinbouw zelf geproduceerde, duurzame energie $(6,3 \mathrm{PJ})$ werd voor een klein deel $(8 \%)$ verkocht. Verkoop vond plaats aan glastuinbouwbedrijven en aan partijen buiten de sector. De inkoop van duurzame energie van buiten de sector groeide met circa $50 \%$. Deze groei was sterker dan de groei van de eigen productie. Per saldo steeg het aandeel inkoop in de consumptie van duurzame energie in 2019 van 31 naar 40\% (figuur 3.4).

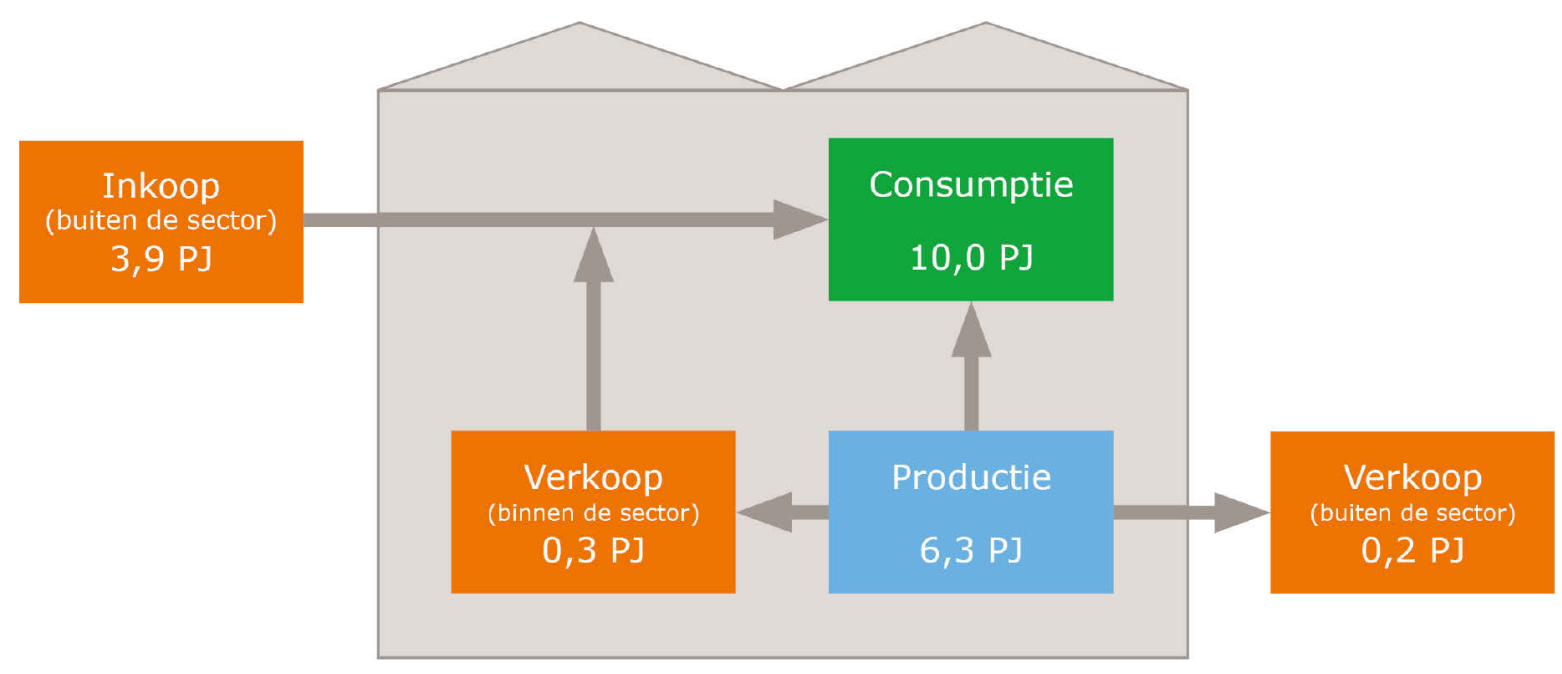

Figuur 3.3 Balans voor duurzame energie van de Nederlandse glastuinbouw in 2019 v) v) Cijfers voorlopig.

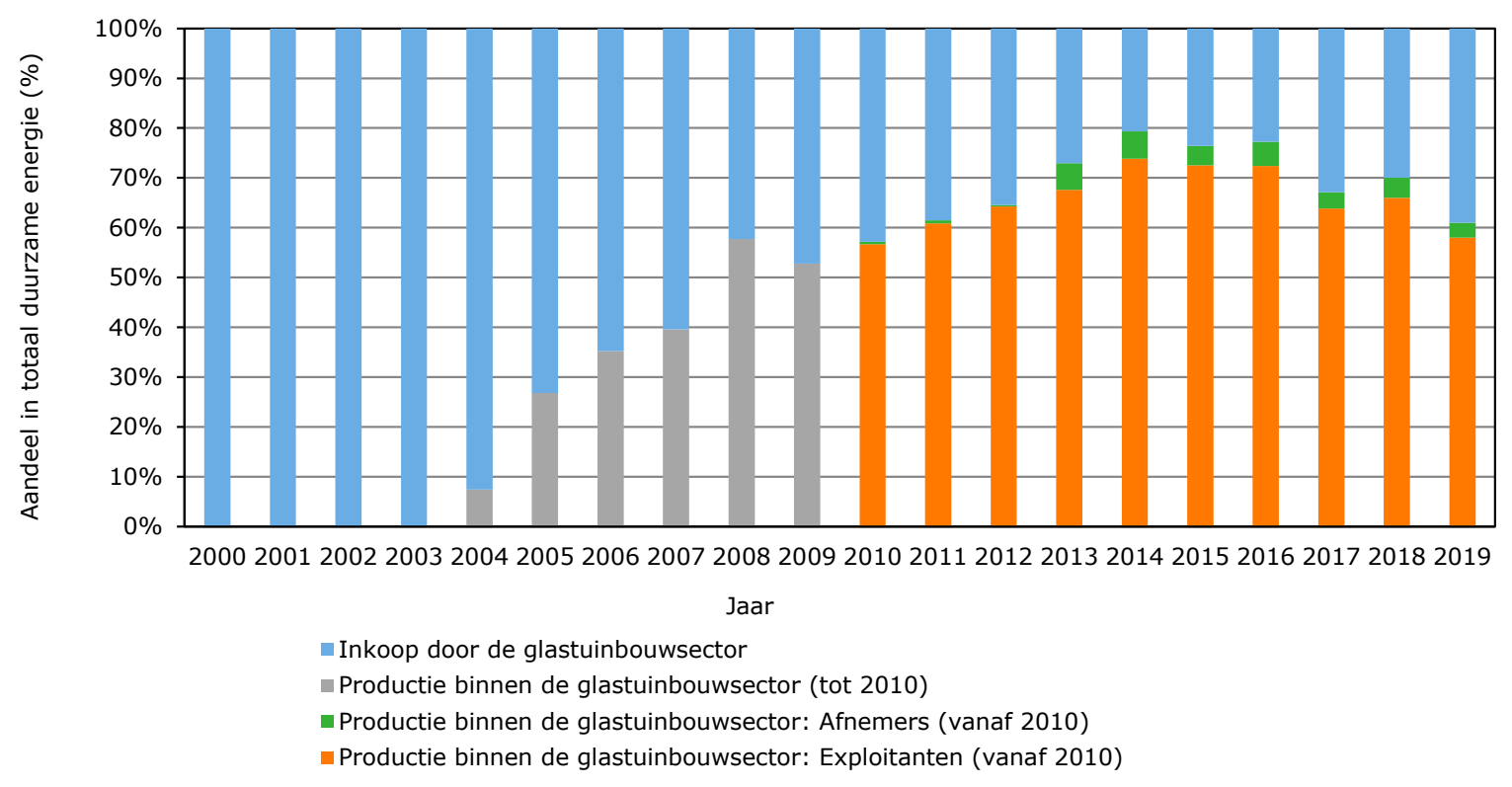

Figuur 3.4 Verdeling van de toepassing van duurzame energie naar herkomst per jaar (\%) a), v) a) Vanaf 2010 is toepassing van door de sector geproduceerde duurzame energie gesplitst naar exploitanten en afnemers.

v) Cijfers 2019 voorlopig. 


\subsubsection{Bedrijfsstructuur}

\section{Bedrijven en areaal}

Het aantal bedrijven met gebruik van duurzame energie (exclusief inkoop uit openbare netten) groeide in 2019 met 19\% naar 304 (figuur 3.5). Deze groei was het saldo van de start van nieuwe projecten, continuering van bestaande projecten en projecten die werden beëindigd. Het areaal met duurzame energie groeide in 2019 met 45\% naar bijna 2.150 ha. Dit was in 2019 ruim $20 \%$ van totale areaal glastuinbouw in Nederland. De groei van het areaal en het aantal bedrijven komt vooral doordat meer bedrijven zijn aangesloten op bronnen die meerdere bedrijven of zelfs op gebiedsniveau duurzame warmte kunnen leveren. Ook was er groei bij decentrale duurzame warmte-inkoop en zijn er nieuwe projecten waar zonne-elektriciteit wordt ingezet. In 2019 was de gemiddelde omvang van een glastuinbouwbedrijf met duurzame energie 7 ha; dit is meer dan twee keer de gemiddelde bedrijfsomvang in de sector (figuur 3.5). De groei van de gemiddelde omvang van bedrijven met duurzame energie komt doordat nieuwe projecten de laatste jaren vooral bij (clusters van) grote en zeer grote bedrijven werden gerealiseerd.

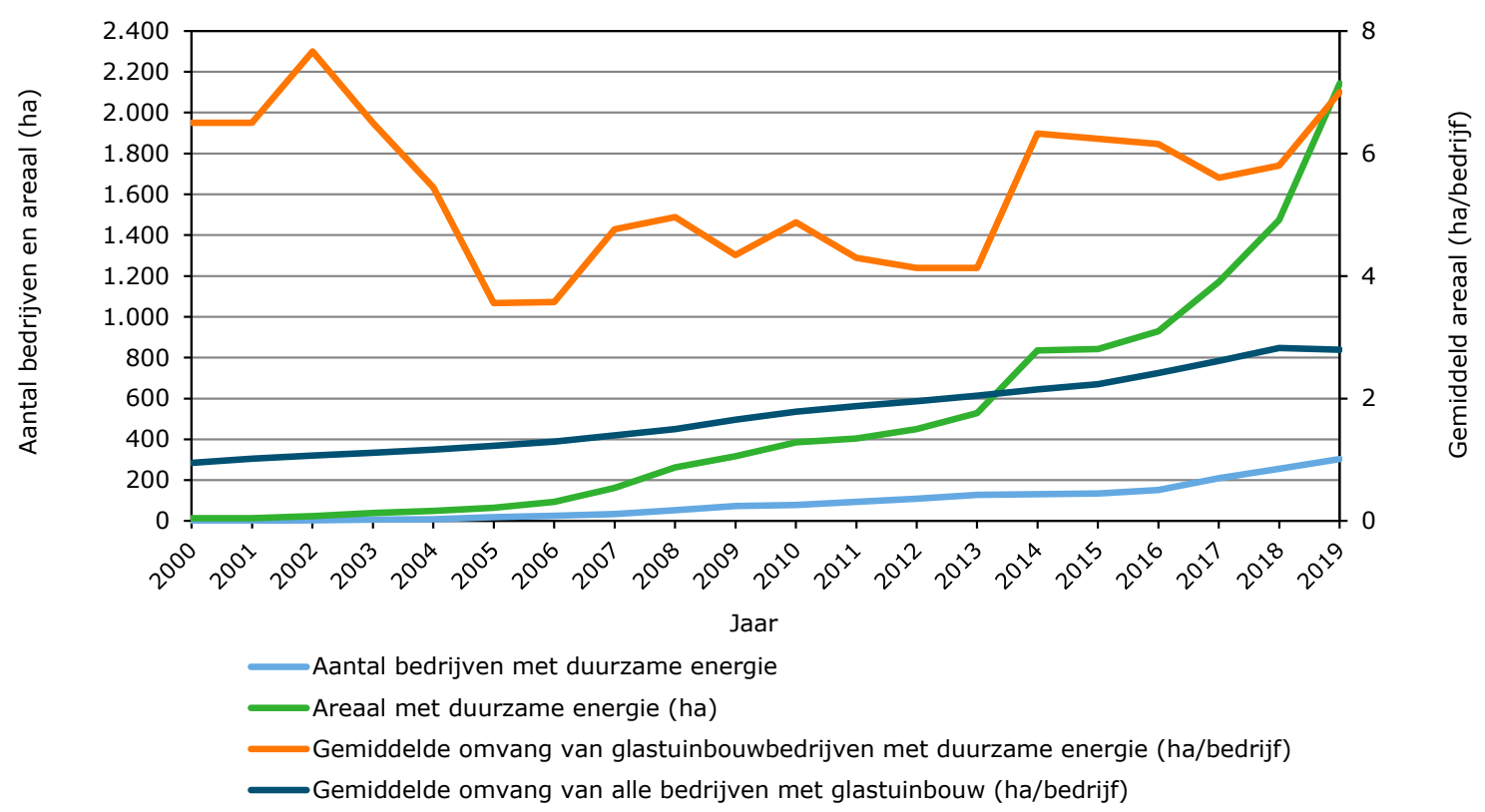

Figuur 3.5 Ontwikkeling van het aantal bedrijven, het areaal en de gemiddelde bedrijfsomvang met duurzame energie en de gemiddelde omvang van alle bedrijven met glastuinbouw a), v)

a) Exclusief inkoop uit openbare netten.

v) Cijfers 2019 voorlopig.

\section{Subsectoren}

In elk van de vier subsectoren in de glastuinbouw wordt duurzame energie toegepast (figuur 3.6). De meeste toepassing vond ook in 2019 plaats op het groenteareaal en het minst bij uitgangsmateriaal. Deze subsectoren zijn qua areaal in Nederland ook de grootste en de kleinste. De arealen met duurzame energie bij bloemen en bij planten zaten hier tussen.

Bij de teelt van bloemen wordt gemiddeld minder warmte en meer groeilicht toegepast en in de vraag naar elektriciteit wordt voor een belangrijk deel voorzien met aardgas-wkk. Hierdoor is het complexer om bij bloemenbedrijven duurzame energie toe te passen. Bij groentebedrijven wordt meer $\mathrm{CO}_{2}$-gedoseerd met wkk en ook dit concurreert met duurzame energie. Door de toename van groeilicht in deze subsector wordt enerzijds ook hier de inzet van duurzame warmte complexer. Anderzijds zijn groentebedrijven vaak relatief groot en die schaalgrootte maakt duurzame energieprojecten vaak sneller rendabel. Er zijn relatief veel potplantenbedrijven die een relatief hoge kastemperatuur hanteren, minder intensief belichten en minder $\mathrm{CO}_{2}$ doseren. Hierdoor ondervindt duurzame energie op deze plantenbedrijven minder concurrentie van aardgasgestookte ketels en wkk. Bij de verdeling van areaal met duurzame energie over de subsectoren (figuur 3.6) nam de laatste jaren het areaal vooral toe bij groente en planten. 


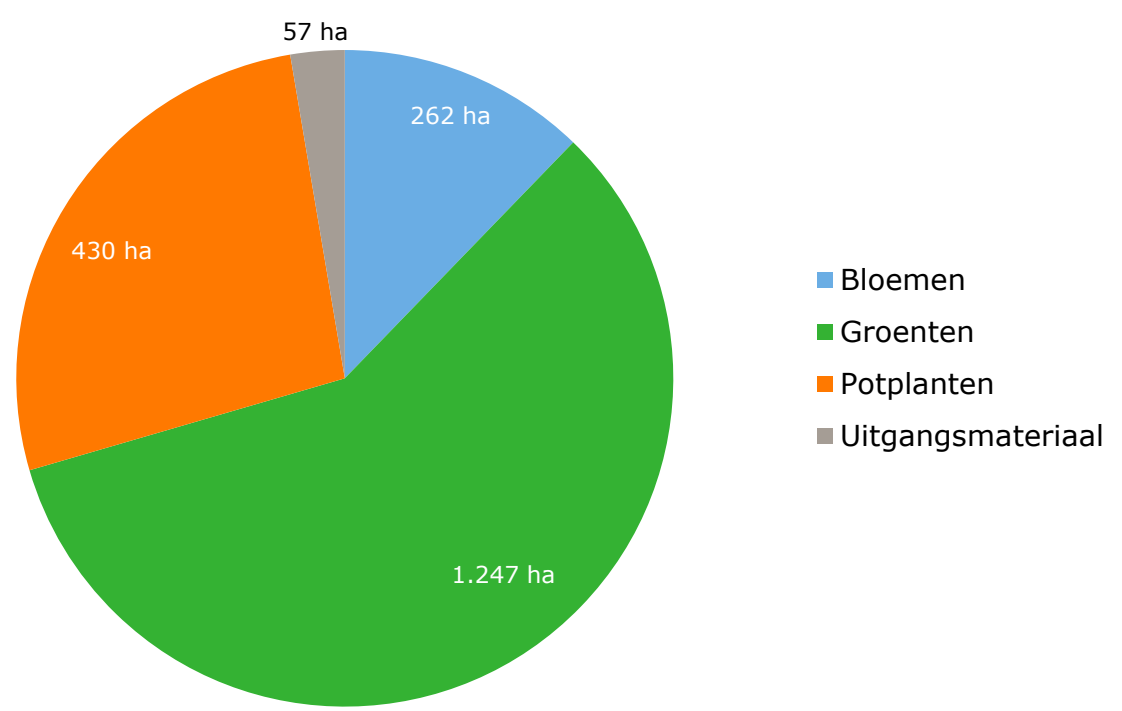

Figuur 3.6 Verdeling van het areaal met duurzame energietoepassing per subsector in 2019 (ha) a), v) a) Exclusief inkoop uit openbare netten.

v) Cijfers voorlopig.

\section{Bedrijfsomvang}

Het grootste deel van de toepassing van duurzame energie door glastuinbouwbedrijven vindt plaats op grotere bedrijven (figuur 3.7). Meer dan $80 \%$ van de duurzame energie wordt toegepast op grote (4-8 ha) en zeer grote ( $>8 \mathrm{ha}$ ) bedrijven. De hoeveelheid duurzame energie toegepast door kleine (1-2 ha) en zeer kleine ( $<1 \mathrm{ha}$ ) bedrijven bedroeg in 2018 3\%. Het aandeel op grotere bedrijven neemt toe en het aandeel op kleinere bedrijven neemt af. Dit hangt enerzijds samen met de schaalvergroting in de sector en met de relatief hoge investeringen die gepaard gaan met duurzame energie, waardoor dit voor kleinere bedrijven moeilijker te realiseren is. Van de 304 bedrijven die in 2019 duurzame energie toepasten, behoorden er 50 tot de groep van zeer grote bedrijven. Samen pasten de bedrijven uit deze groep circa $60 \%$ van de duurzame energie toe op circa 1.250 ha. Dit betrof vooral aardwarmte en inkoop duurzame warmte van derden. De toepassing door kleine en zeer kleine bedrijven was hoofdzakelijk warmte uit biobrandstof en zonnewarmte.

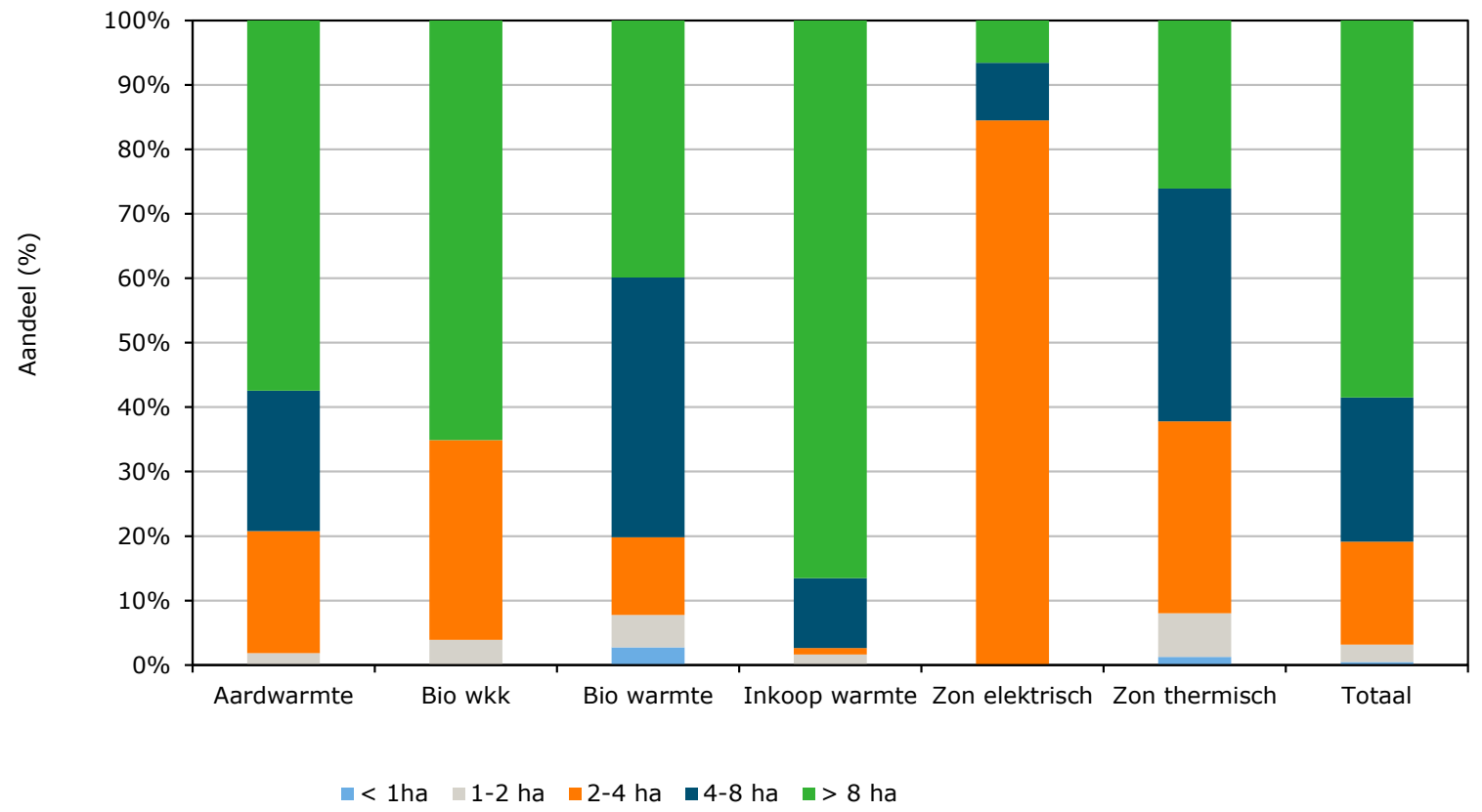

Figuur 3.7 Verdeling volume duurzame energie over bedrijfsgrootteklassen per vorm in 2019 (\%) v) v) Cijfers voorlopig. 


\section{3 $\mathrm{CO}_{2}$-emissiereductie}

Productie, inkoop en verkoop van duurzame energie door de glastuinbouw reduceert zowel binnen als buiten de glastuinbouw de $\mathrm{CO}_{2}$-emissie. Verandering van de $\mathrm{CO}_{2}$-emissie kan zowel op sectorniveau (op basis van de IPCC-methode) als op nationaal niveau (op basis van het primair brandstofverbruik) worden uitgedrukt. De reductie van de $\mathrm{CO}_{2}$-emissie door duurzame energie op sectorniveau bedroeg in 2019 0,47 Mton en de nationale reductie 0,59 Mton (tabel 3.2). Uit de tabel blijkt dat op sectorniveau en op nationaal niveau de grootste bijdrage van aardwarmte kwam. Op sectorniveau was inkoop van duurzame warmte van derden eveneens belangrijk. Op nationaal niveau waren inkoop van duurzame elektriciteit en duurzame warmte van derden belangrijk. Dit verschil komt doordat inkoop en productie van duurzame elektriciteit inkoop van niet-duurzame elektriciteit vervangt en de inkoop van elektriciteit bij de IPCC-methode niet tot emissietoekenning aan de glastuinbouwsector leidt.

Tabel 3.2 Reductie $\mathrm{CO}_{2}$-emissie per duurzame energiebron in $2019 \mathrm{v}$ )

\begin{tabular}{|c|c|c|c|c|}
\hline \multirow[t]{2}{*}{ Duurzame energiebron } & \multicolumn{2}{|c|}{ Sectoraal/IPPC-methode } & \multicolumn{2}{|c|}{$\begin{array}{l}\text { Nationaal/Primair Brandstof- } \\
\text { methode }\end{array}$} \\
\hline & Mton & $\%$ & Mton & $\%$ \\
\hline Biobrandstof (wkk) & 0,01 & 2 & 0,02 & 4 \\
\hline Biobrandstof (warmte) & 0,05 & 10 & 0,05 & 8 \\
\hline Zonne-energie (warmte) & 0,04 & 9 & 0,02 & 3 \\
\hline Inkoop duurzaam gas & $<0,01$ & $<1$ & $<0,01$ & $<1$ \\
\hline Inkoop duurzame elektriciteit & - & 0 & 0,16 & 26 \\
\hline Inkoop duurzame warmte (centraal) & 0,04 & 8 & 0,04 & 7 \\
\hline
\end{tabular}

v) Cijfers voorlopig.

In de periode 2005-2019 nam de bijdrage die duurzame energie heeft in de reductie van de $\mathrm{CO}_{2}$-emissie op sectorniveau (IPCC-methode) geleidelijk toe van 0,02 tot 0,47 Mton (figuur 3.8). Hierbinnen was in 2019 de reductie door de productie van duurzame energie twee keer zo groot dan de reductie door inkoop van duurzame energie. Op nationaal niveau (primair brandstof) nam de bijdrage die duurzame energie in de reductie van de $\mathrm{CO}_{2}$-emissie in de periode 2005-2019 toe van 0,05 Mton tot 0,59 Mton (figuur 3.8). Hierbij waren in 2019 de reductie door duurzame energieproductie door de sector zelf en de reductie door inkoop van buiten de sector globaal gelijkwaardig in hun bijdrage. Een van de kenmerken van deze indicator is dat als buiten de sector de inzet van primair brandstof verandert door verandering van de energiehuishouding van de glastuinbouw, zoals inkoop elektriciteit, dit wel van invloed is. Over alle jaren is de reductie op nationaal niveau groter dan op sectorniveau. Dit komt doordat op nationaal niveau de inkoop en verkoop van duurzame elektriciteit wel meetelt.

Duurzame energie had in 2019 een positieve bijdrage aan verbetering van de energie-efficiëntie van de glastuinbouw met ruim 5 procentpunten. 


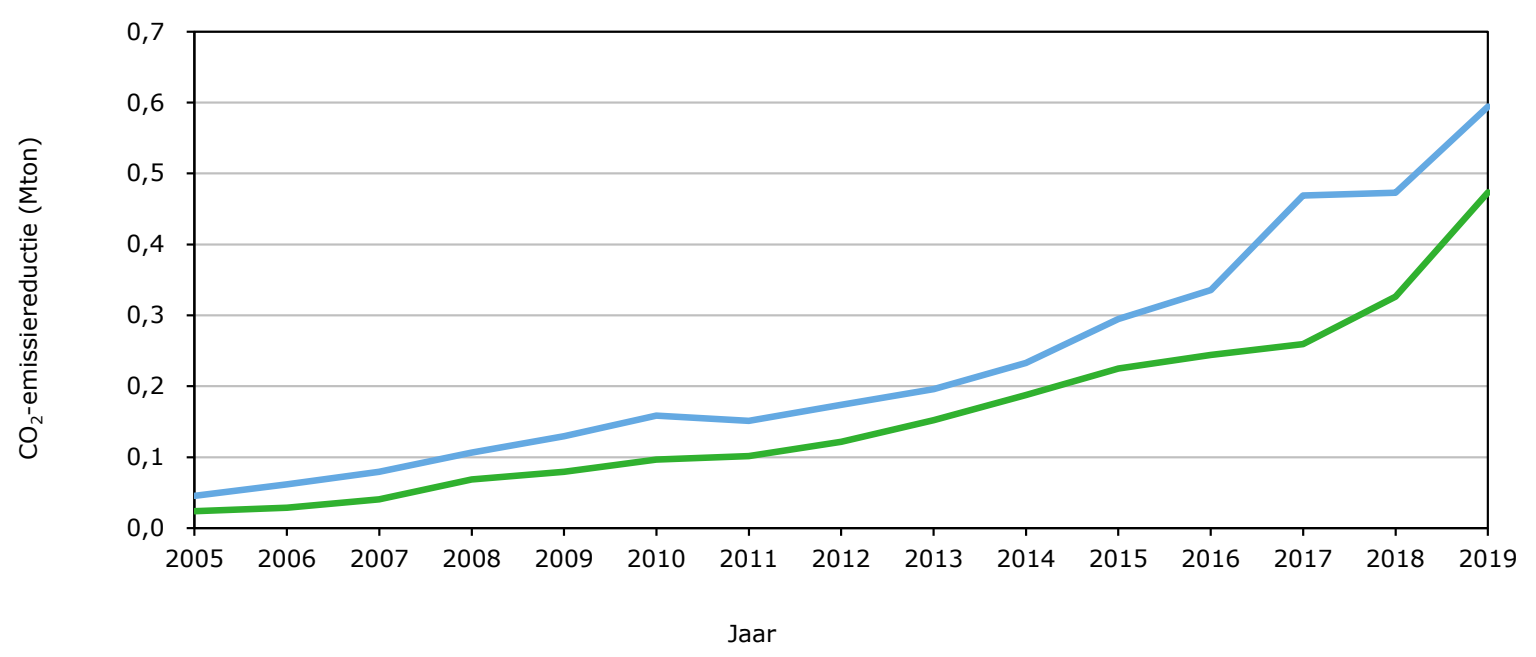

$-\mathrm{CO}_{2}$-emissiereductie; nationaal/primair brandstof $=\mathrm{CO}_{2}$-emissiereductie; sector/IPCC-methode

Figuur 3.8 Ontwikkeling reductie $\mathrm{CO}_{2}$-emissie van de glastuinbouw door duurzame energie op basis van primair brandstof en IPCC-methode. $v$ )

v) Cijfers 2019 voorlopig.

\subsection{Warmtedekking}

Duurzame warmtebronnen voorzien in de glastuinbouw op het areaal waar de bronnen worden ingezet, een deel van de warmtevraag. De mate waarin in de warmtevraag wordt voorzien wordt de dekking genoemd en kan worden uitgedrukt in $\mathrm{m}^{3}$ aardgasequivalenten (a.e.) per $\mathrm{m}^{2}$ per jaar. De dekking bepaalt de reductie van de $\mathrm{CO}_{2}$-emissie in $\mathrm{kg} \mathrm{CO}_{2}$ per $\mathrm{m}^{2}$ kas door de duurzame warmtebron en wordt beïnvloed door: (1) de warmtevraag, (2) het absolute vermogen van de bron, (3) de gebruiksduur van de bron, (4) het areaal dat de bron van warmte voorziet en (5) de $\mathrm{CO}_{2}$-voorziening. In 2019 was de gemiddelde dekking met duurzame warmte op het areaal met deze bronnen $14 \mathrm{~m}^{3}$ a.e. per $\mathrm{m}^{2}$. Dit is circa 1 a.e. per $\mathrm{m}^{2}$ lager dan in 2018.

Verschillen tussen warmtebronnen

Rondom de gemiddelde dekking zit spreiding: Het verschilt per duurzame bron en per project. Bij projecten met zonnewarmte is de dekking gemiddeld laag en de spreiding tussen projecten klein. Dit komt door de functionele verbinding met de teelt (koeling). Bij projecten met inkoop van duurzame warmte is de dekking relatief hoog en de spreiding klein. Dit komt door gelijksoortige contractvoorwaarden en afspraken tussen afnemer en leverancier. Bij projecten met aardwarmte en biobrandstof is de spreiding groot. De lage dekking heeft meerdere oorzaken. Ten eerste hebben deze bronnen geen functionele verbinding met de teelt, zoals bij zonnewarmte. Ten tweede is bij deze bronnen de projectoptimalisatie anders. Er zijn projecten met aardwarmte en biobrandstof die ingericht zijn om een maximale invulling van de warmtevraag per $\mathrm{m}^{2}$ op het glastuinbouwbedrijf te realiseren en er zijn projecten die een maximale benutting van de warmtebron nastreven. Bij maximale invulling is de dekking hoger, maar is er - vooral in de zomer- onbenut warmtevermogen. Bij maximale benutting is de gebruiksduur langer en de dekking lager. Hierdoor zal er in de winterperiode meer warmte nodig zijn vanuit andere warmtebronnen. Uit de spreiding tussen de afzonderlijke projecten met aardwarmte en biobrandstof kan worden afgeleid dat een hogere warmte dekking wel mogelijk is.

Maximale benutting duurzame warmtebron

Deze variant is vooral de laatste jaren populair. Enerzijds is bij maximale benutting de gebruiksduur langer en is ondersteuning vanuit de SDE+-regeling het grootst. Bij het maximeren van de gebruiksduur hoort een kleinere warmtecapaciteit $\left(\mathrm{W} / \mathrm{m}^{2}\right)$ en hierdoor is de bijbehorende warmtedekking laag. Anderzijds is het voor projectpartners en financiers belangrijk dat het 
projectrisico door meerdere bedrijven wordt gedragen. Hierdoor worden meer bedrijven en een groter areaal aangesloten en is de warmtecapaciteit $\left(\mathrm{W} / \mathrm{m}^{2}\right)$ kleiner. Voor aardwarmte komt daar nog bij dat de mate van regelbaarheid beperkt is, in vergelijking met bijvoorbeeld aardgas wkk. Ook is belangrijk dat op bedrijven met belichting gasgestookte wkk's elektriciteit en rookgas $\mathrm{CO}_{2}$ kunnen blijven produceren en de warmte benut kan blijven worden. In 2019 werd op ruim $80 \%$ van het areaal met geothermie ook energie en $\mathrm{CO}_{2}$ toegepast vanuit aardgas wkk. Hiernaast heeft het grootste deel van het areaal met duurzame warmte zonder wkk toegang tot externe $\mathrm{CO}_{2}$.

\section{Gerealiseerde dekking}

De warmtedekking van de afzonderlijke duurzame warmtebronnen verschilt per project. Ook is de mix van de afzonderlijke bronnen in de totale hoeveelheid duurzame warmte de afgelopen jaren veranderd. Hierdoor dient de ontwikkeling van de gemiddelde dekking in de tijd per bron te worden bezien. Uit de achterliggende data van de bestaande projecten met duurzame warmte (paragraaf 3.2) blijkt dat de gemiddelde dekking van de meeste duurzame warmtebronnen in de periode 2014-2019 ten opzichte van de periode $2010-2013$ is gedaald. Een illustratie hiervan is in figuur 3.9 weergegeven voor aardwarmte.
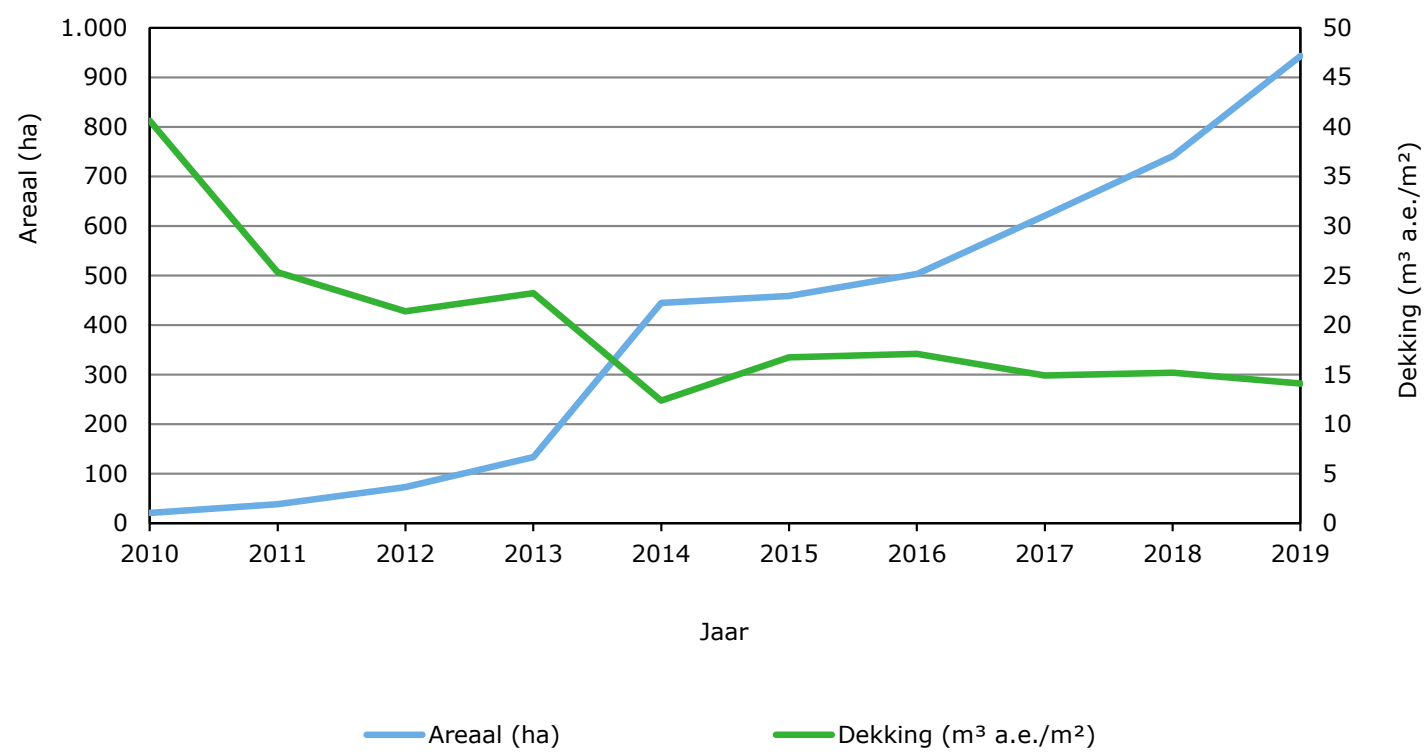

Figuur 3.9 Ontwikkeling van het areaal met aardwarmte en de gemiddelde warmtedekking van aardwarmteprojecten in de Nederlandse glastuinbouw $v$ )

v) Cijfers 2019 voorlopig.

\section{Nadelen}

Maximale benutting van een duurzame bron heeft naast voordelen ook nadelen. Het is voor te stellen dat op een gegeven moment het bereikbaar potentieel van het totaal areaal met een beperkte basislast door een warmtebron zonder $\mathrm{CO}_{2}$-emissie voorzien wordt. $\mathrm{Er}$ is dan veel areaal met gebruik van deze warmte, maar de mate waarin reductie van de $\mathrm{CO}_{2}$-emissie per $\mathrm{m}^{2}$ plaatsvindt is beperkt (figuur 3.9). De groei van het gebruik van duurzame warmte loopt dan tegen grenzen aan. Er zijn dan extra bronnen nodig om de dekking en de emissiereductie te verhogen. Bij het verhogen van basislast vermogen naar middenlast maken deze extra bronnen minder draaiuren en hierdoor is het investeringsrendement lager. Infrastructuur van bestaande installaties kan onvoldoende capaciteit hebben, waardoor nieuwe infrastructuur aangelegd moet worden. Dit is evenmin gunstig voor projectrendementen. Er zal ook meer elektriciteit en $\mathrm{CO}_{2}$ ingekocht moeten worden, zodat warmte uit deze bronnen het uitfaseren van wkk ook mogelijk maakt, bekeken vanuit de totale energievoorziening op bedrijven.

Hiernaast is het belangrijke stimuleringsinstrument vanuit de rijksoverheid, de SDE $(+/++)$, gericht op kostenefficiëntie. Dit is gunstig voor het realiseren van individuele projecten met maximale benutting (met hoge bedrijfstijd leveren van basislast). Het is ongunstig voor projecten met grotere vermogens, hogere dekking en lagere bedrijfstijden, want deze projecten zijn minder kostenefficiënt. 
Stevige competitie met wkk-warmte en de insteek van stimuleringsmaatregelen (SDE) zijn hierom knelpunten bij het realiseren van de doelen en ambities van de $\mathrm{CO}_{2}$-emissiereductie op sectorniveau.

\subsection{Inkoop $\mathrm{CO}_{2}$}

Naast dat de glastuinbouw $\mathrm{CO}_{2}$ uitstoot, wordt $\mathrm{CO}_{2}$ ook gebruikt als meststof voor een optimale productie van de gewassen. Deze $\mathrm{CO}_{2}$ is in de huidige situatie vooral afkomstig van de rookgassen van aardgasgestookte wkk's en. Bij het vervangen van fossiele brandstof door energiebronnen zonder $\mathrm{CO}_{2}$-emissie, valt de $\mathrm{CO}_{2}$-voorziening - en daarmee een essentiële productiefactor - weg. De overgang naar duurzame energie en inkoop van warmte kan daardoor niet zonder het gebruik van externe $\mathrm{CO}_{2}$. (Van der Velden en Smit, 2019) Hiernaast kan de inzet van externe $\mathrm{CO}_{2}$ de zomerstook verminderen en wordt externe $\mathrm{CO}_{2}$ gebruikt door glastuinbouwbedrijven die het mogelijke risico van schadelijke elementen in de rookgassen te groot achten. Met zomerstook wordt de $\mathrm{CO}_{2}$-productie uit aardgas zonder warmtebenutting bedoeld en het vermijden hiervan is energiebesparing. In 2019 werd zo'n 0,71 Mton $\mathrm{CO}_{2}$ extern ingekocht en dat is bijna $5 \%$ meer dan in 2018. De gemiddelde toepassing van externe $\mathrm{CO}_{2}$ op het totale areaal in de sector kwam hiermee in 2019 op 7,3 kg per m². In de periode 2009-2013 nam de jaarlijkse inkoop af, maar vanaf 2013 was er groei. De eerdere daling hangt samen met de krimp van het areaal en de lagere economische groei in die periode. De toename vanaf 2013 duidt er op dat bedrijven meer $\mathrm{CO}_{2}$ inkopen voor productieoptimalisatie en er externe $\mathrm{CO}_{2}$ nodig bij de ingebruikname van duurzame warmtebronnen en uitbreiding van de aankoop van warmte bij derden. De groei zat vooral bij vaste leveringsovereenkomsten met vaste jaarkosten (vermogen), terwijl er daling was van het gebruik via variabele levering (aankoop van losse eenheden). De groei in 2019 is het saldo van nieuwe gebruikers, toegenomen consumptie bij bestaande gebruikers, leveringsonderbrekingen, vraaguitval door bedrijven die stoppen en extra $\mathrm{CO}_{2}$-productie door toename van de verkoop met de aardgas-wkk's.

Circa een derde van het areaal met duurzame energie was te vinden in de gebieden met centrale levering van externe $\mathrm{CO}_{2}$. Voor de verdere ontwikkeling van het gebruik van duurzame energie en warmte van derden is toename van de externe $\mathrm{CO}_{2}$-voorziening en verhoging van de leveringszekerheid van groot belang. Externe $\mathrm{CO}_{2}$ komt beschikbaar als bijproduct van industriële processen. Onderscheid is te maken tussen $\mathrm{CO}_{2}$ van fossiele en van biogene oorsprong; beiden komen voor. Ook is onderscheid te maken tussen centrale en decentrale levering (figuur 3.10). Het gebruik van externe $\mathrm{CO}_{2}$ in de glastuinbouw betreft vooral centrale levering van zuivere $\mathrm{CO}_{2}$ met distributie via een leidingnetwerk. Decentrale levering van zuivere $\mathrm{CO}_{2}$ per as volgt qua hoeveelheid op afstand en dit is de laatste jaren vooral in gebieden zonder leidingnetwerk groeiende.

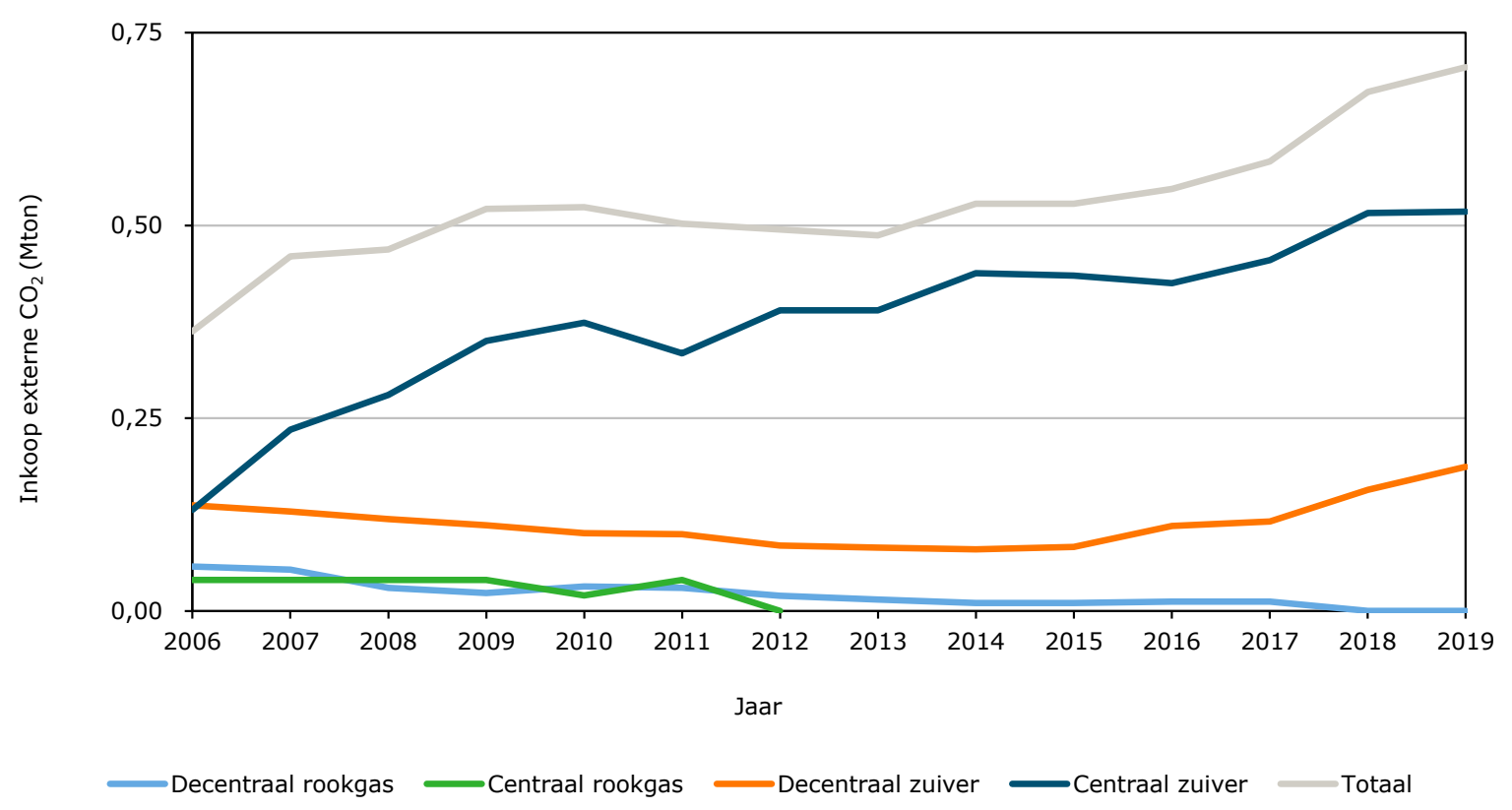

Figuur 3.10 Ontwikkeling van de inkoop van externe $\mathrm{CO}_{2}$ door de Nederlandse glastuinbouw v) v) Cijfers 2019 voorlopig. 


\section{$4 \quad$ Analyse wkk, inkoop van warmte en elektriciteitsbalans}

\subsection{Inleiding}

De glastuinbouw maakt op grote schaal gebruik van warmtekrachtkoppeling (wkk). Met wkk wordt warmte en elektriciteit geproduceerd. De warmte die vrijkomt bij elektriciteitsproductie met fossiele brandstof wordt hiermee nuttig gebruikt (Smit en Van der Velden, 2008). Ook kan de $\mathrm{CO}_{2}$ uit rookgassen benut worden voor de groei van het gewas.

Het gebruik van wkk in de glastuinbouw betreft vooral aardgasmotoren van de glastuinbouwbedrijven (paragraaf 4.2). In deze rapportage worden met wkk deze installaties bedoeld. ${ }^{7}$ Daarnaast wordt gebruik gemaakt van restwarmte van elektriciteitscentrales of industrie. Bij deze energievoorziening koopt de glastuinbouw warmte (paragraaf 4.3) en eventueel $\mathrm{CO}_{2}$ (paragraaf 3.5) in. Inkoop van warmte uit aardgas wkk's van energiebedrijven is met ingang van 2019 verwaarloosbaar.

Door de inkoop van warmte wordt zowel de $\mathrm{CO}_{2}$-emissie van de glastuinbouw (IPCC-methode) als het primair brandstofverbruik - en dus de nationale $\mathrm{CO}_{2}$-emissie - verminderd (paragraaf 4.4). Door de wkk's van de glastuinbouw wordt ook primair brandstof bespaard en dus de nationale $\mathrm{CO}_{2}$-emissie verlaagd. De wkk's gebruiken aardgas en dit verhoogt de $\mathrm{CO}_{2}$-emissie van de glastuinbouw (IPPC-methode).

De exploitatie van wkk door glastuinbouwbedrijven is sinds jaren van grote invloed op de elektriciteitsbalans en op de energiekosten van de glastuinbouw. De elektriciteitsbalans wordt behandeld in paragraaf 4.5 en de energiekosten zijn behandeld in paragraaf 2.6. Op beperkte schaal gebruikt de glastuinbouw ook wkk's die draaien op biobrandstof en wordt er duurzame warmte ingekocht van wkk's van derden die draaien op biobrandstof en vanuit andere duurzame bronnen. Dit is duurzame energie en is in beschouwing genomen bij duurzame energie in hoofdstuk 3 en maakt geen deel uit van de cijfers in hoofdstuk 4, tenzij anders aangegeven.

\subsection{Wkk glastuinbouwbedrijven}

\section{Vermogen en areaal}

Het totale elektrische vermogen van de wkk's van tuinders is in 2019 toegenomen tot circa 2.050 $\mathrm{MW}_{\mathrm{e}}$. In de periode 2011-2018 schommelde dit tussen de 2.400 en 2.500 $\mathrm{MW}_{\mathrm{e}}$. Deze mutaties hingen samen met de ontwikkeling van de spark spread (paragraaf 2.6) en van het areaal glastuinbouw. In 2019 was op circa 6.000 ha een aardgas wkk in gebruik, dit is circa $62 \%$ van het totaal areaal glastuinbouw.

\section{Gebruik elektriciteit}

De door de wkk's geproduceerde elektriciteit werd in 2019 voor circa 56\% op de elektriciteitsmarkt verkocht en voor circa 44\% door de glastuinbouw zelf gebruikt. In 2010 waren deze aandelen $88 \%$ en $12 \%$. Vanaf 2010 er een verschuiving opgetreden van verkoop van de geproduceerde elektriciteit met aardgas wkk's naar eigen consumptie. Het eigen gebruik hangt hoofdzakelijk samen met de groei van het elektriciteitsgebruik door belichting in de glastuinbouw (paragraaf 2.7). Verkoop van elektriciteit vindt plaats bij vrijwel alle bedrijven met een wkk. Door bedrijven zonder groeilicht wordt bijna alle elektriciteit verkocht, door bedrijven met groeilicht wordt meer zelf gebruikt en minder verkocht.

\footnotetext{
7 Een beperkt deel van de wkk's in gebruik op glastuinbouwbedrijven is ondergebracht in aparte 'energie-bv's'. In de Energiemonitor Glastuinbouw worden deze installaties beschouwd als wkk's van de glastuinbouw (zie Protocol).
} 


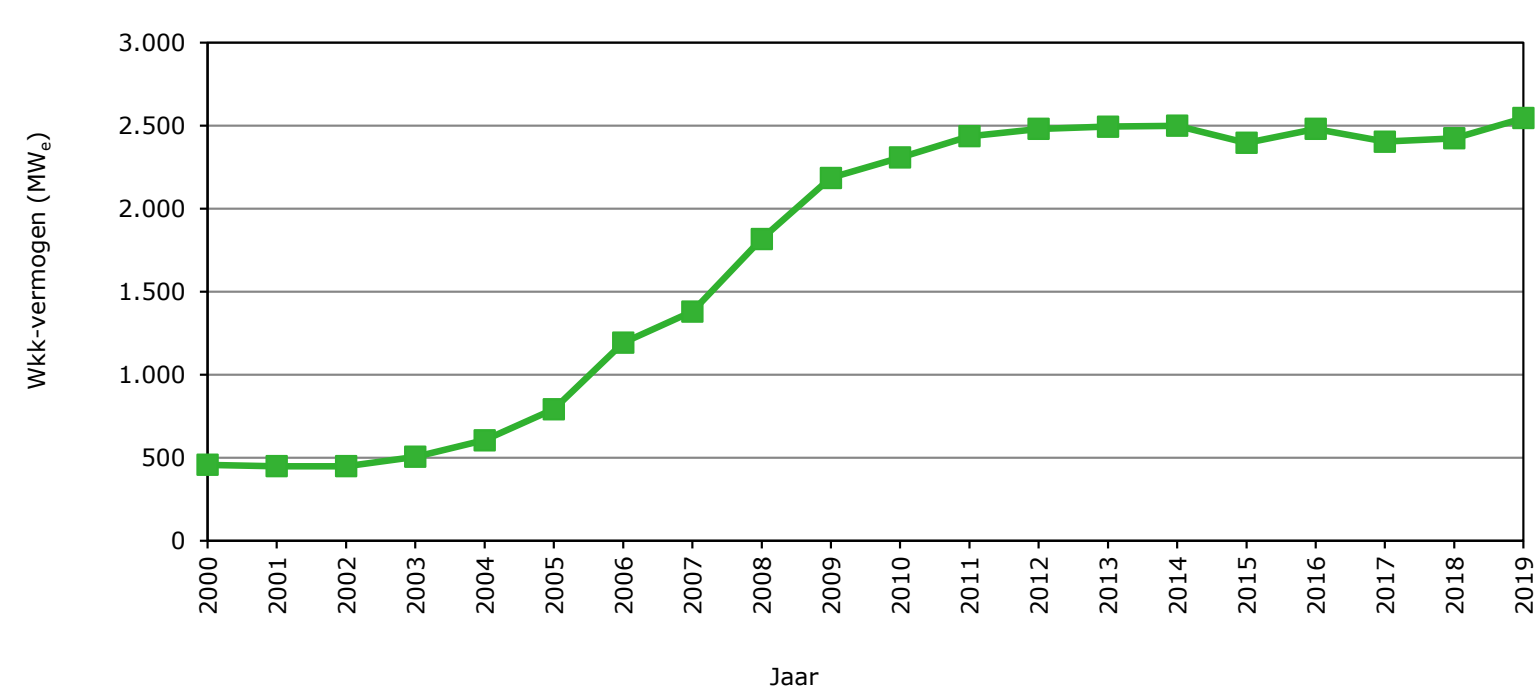

Figuur 4.1 Wkk-vermogen glastuinbouw

Bron: Landbouwtelling, bewerking Wageningen Economic Research.

Nieuwe installaties.

Uit een inventarisatie door BlueTerra bij wkk-leveranciers is gebleken dat zowel in 2018 als in 2019 zo'n 40 tot $45 \mathrm{MW}_{\mathrm{e}}$ aan nieuw vermogen van aardgas wkk's aan de glastuinbouw is geleverd (Hoek en Schlattman, 2020). Dit nieuwe wkk vermogen is voor bijna $80 \%$ in gebruik genomen door bedrijven met belichting. Het in gebruik nemen van nieuwe wkk's vindt dus vooral plaats door bedrijven met belichting. Voor 2020 wordt hierin weinig verandering verwacht.

\section{$\mathrm{CO}_{2}$-dosering}

De verkoop van elektriciteit vindt vooral overdag plaats. In deze uren is de elektriciteitsprijs hoger. Bovendien past dit bij de behoefte aan $\mathrm{CO}_{2}$ die de gewassen juist overdag hebben. De gereinigde rookgassen van de wkk's worden op grote schaal toegepast voor $\mathrm{CO}_{2}$-dosering bij de gewassen. Door het gebruik van wkk komt er per eenheid warmte meer $\mathrm{CO}_{2}$ beschikbaar dan bij warmteproductie met de aardgasketel. Er wordt immers ook aardgas verbrand voor elektriciteitsproductie. Deze extra rookgas $-\mathrm{CO}_{2}$ is gunstig voor de groei van het gewas en hiermee de ontwikkeling van de fysieke productie (paragraaf 2.2).

\section{Gebruiksduur}

In 2019 was de gemiddelde gebruiksduur (equivalente vollast-uren per jaar) van de wkk's bijna 4.100 uur. Vanaf 2016 heeft de gebruiksduur een toename laten zien. In 2019 was de gebruiksduur bijna een kwart langer dan in 2016 (figuur 4.2). In de periode 2012-2016 was er een dalende trend (figuur 4.2). Deze ontwikkelingen hingen samen met de ongunstige spark spread in die periode (paragraaf 2.6). In de periode na 2016 is de spark spread sterk verbeterd. Hierdoor waren er gedurende het jaar respectievelijk minder en meer uren waarin het aantrekkelijk was om elektriciteit te verkopen of te gebruiken in plaats van in te kopen. Daarnaast is de eigen consumptie van de geproduceerde elektriciteit van invloed op de gebruiksduur. De eigen consumptie laat vanaf 2016 in absolute hoeveelheden een stijgende trend zien. 


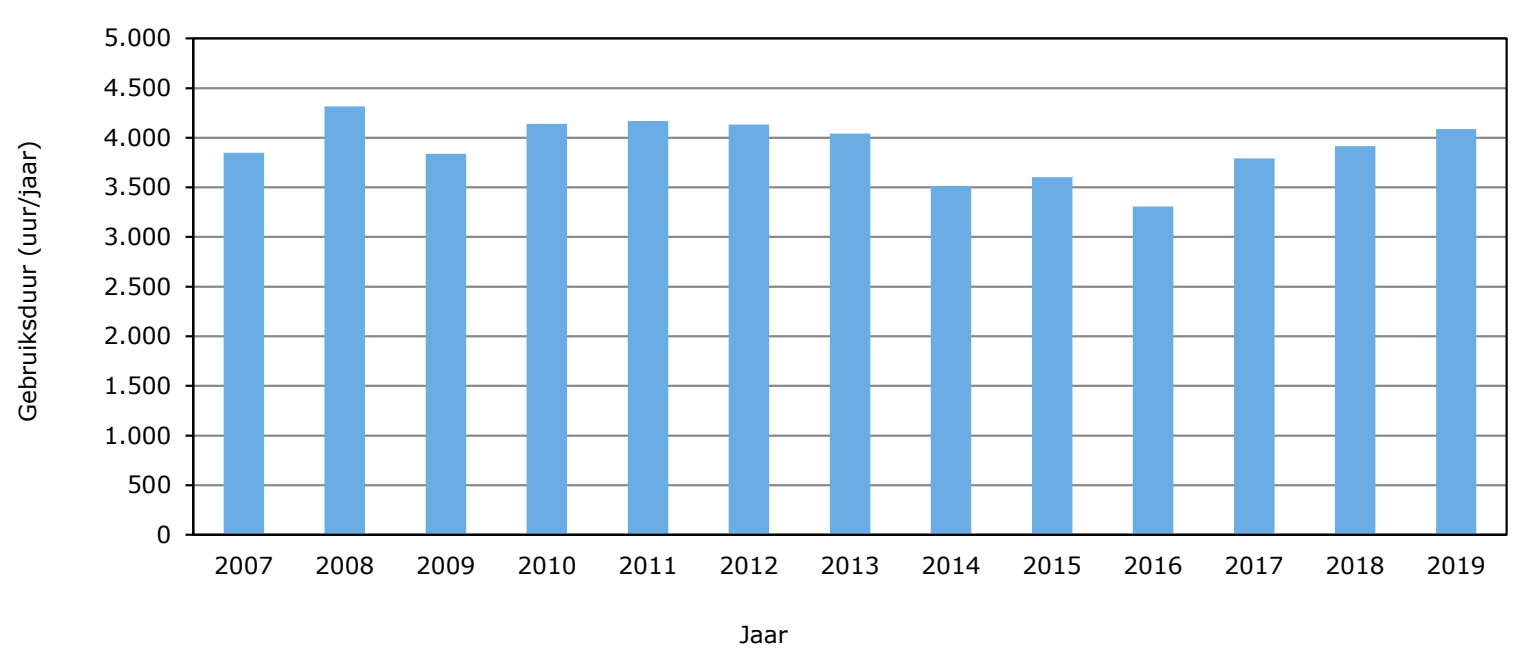

Figuur 4.2 Globale gemiddelde gebruiksduur wkk tuinders a)

a) Cijfers 2019 voorlopig.

\subsection{Inkoop van warmte}

De glastuinbouw koopt in 2019 (niet duurzame) warmte in van elektriciteitscentrales en industrie. Tot in 2018 werd er ook warmte ingekocht vanuit wkk's van energiebedrijven. Dat is 2019 niet meer het geval. In 2019 werd 2,8 PJ warmte ingekocht van leveranciers van buiten de glastuinbouw (figuur 4.3). Dit is 2,6\% van het totale energiegebruik en 3,6\% van de warmteconsumptie door de glastuinbouw. De ingekochte warmte uit niet-duurzame bronnen werd toegepast op circa 500 ha.

De inkoop van warmte neemt sinds het einde van de vorige eeuw af. Dit kwam door de uit gebruik name van meerdere regionale restwarmteprojecten. Vanaf 2014 liet de inkoop van warmte een lichte toename zien. Dit kwam door uitbreiding van het areaal kassen bij bestaande warmteprojecten. De laatste jaren neemt de omvang inkoop van warmte af doordat een groeiend deel van de ingekochte warmte door de centrales wordt geproduceerd met biobrandstof. Deze duurzame fractie is hier buiten beschouwing gelaten en telt mee als inkoop van duurzame energie (hoofdstuk 3 ).

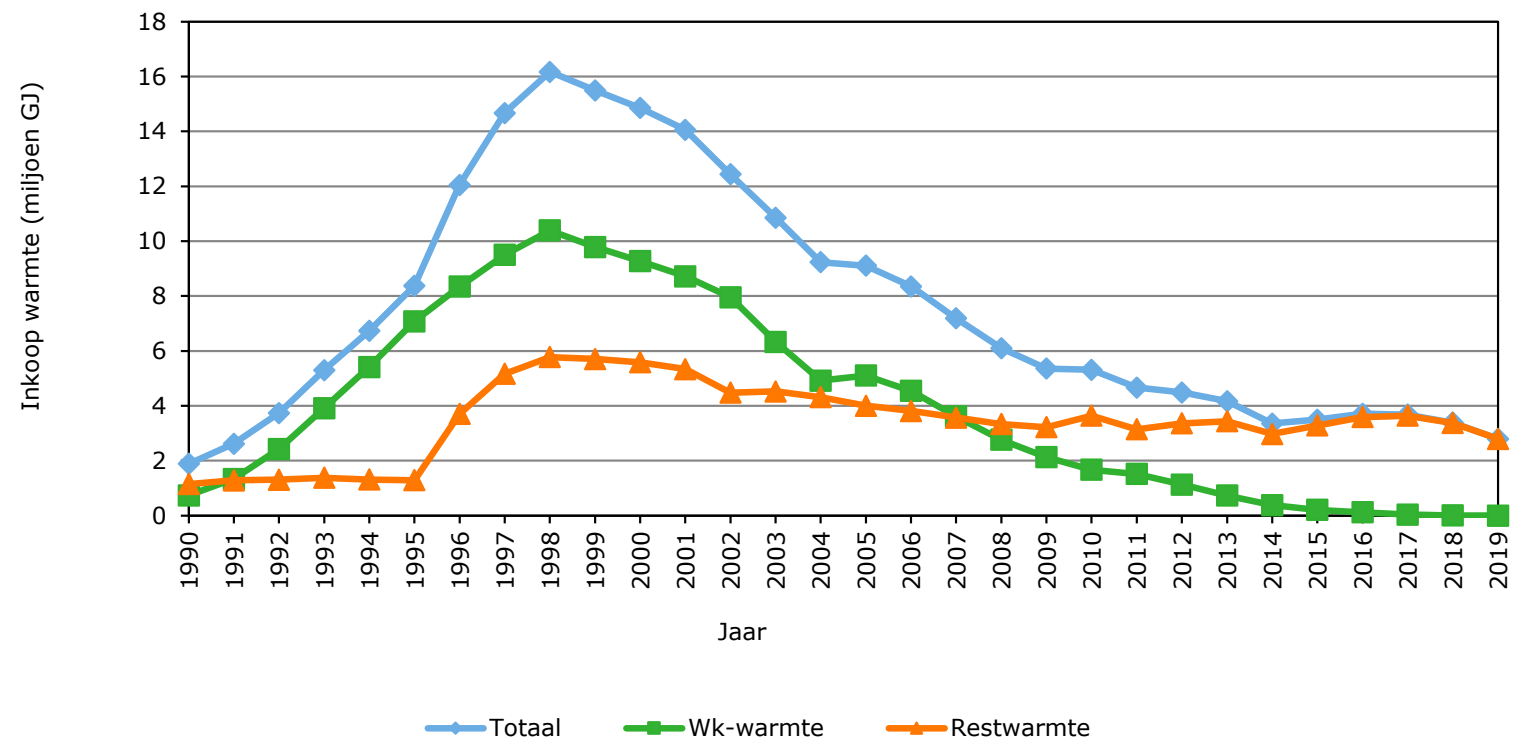

Figuur 4.3 Inkoop van warmte door de glastuinbouw a)

a) Cijfers 2019 voorlopig. 


\subsection{Reductie $\mathrm{CO}_{2}$-emissie}

\section{Achtergronden}

De reductie van de $\mathrm{CO}_{2}$-emissie door wkk kan op twee manieren worden bepaald. De ene insteek is de $\mathrm{CO}_{2}$-emissie c.q. het fossiele brandstofverbruik op sectorniveau. De andere insteek is de $\mathrm{CO}_{2}$-emissie nationaal c.q. het primair brandstofgebruik. De inzet van wkk door de tuinbouw is van invloed op de $\mathrm{CO}_{2}$-emissie binnen en buiten de glastuinbouw. Er wordt aardgas ingekocht en elektriciteit verkocht. Hierdoor neemt de $\mathrm{CO}_{2}$-emissie van de glastuinbouwsector toe (IPCC-methode), terwijl dit bij elektriciteitscentrales afneemt. Het laatste effect is groter dan de toename van de emissie in de glastuinbouw, waardoor per saldo op nationaal niveau $\mathrm{CO}_{2}$-emissie wordt vermeden. Hierdoor is het effect van wkk en van inkoop van warmte op de $\mathrm{CO}_{2}$-emissie op nationaal niveau gekwantificeerd op basis van het primair brandstofverbruik.

\section{Wkk tuinders}

De wkk's van de tuinders reduceren het primair brandstofverbruik substantieel. In 2019 is de reductie opgelopen tot bijna 1 miljard $\mathrm{m}^{3}$ a.e. c.q. 1,8 Mton $\mathrm{CO}_{2}$. Over de gehele periode 2014-2019 trad een beperkte toename op. De grootste nationale reductie met wkk (2,0 Mton) werd gerealiseerd in 2012. Ondanks dat er in 2019 meer elektriciteitsproductie met de wkk's in de glastuinbouw plaatsvond is de reductie van de $\mathrm{CO}_{2}$-emissie in 2019 lager. Dit komt door de verbeterde gemiddelde efficiëntie van de elektriciteitscentrales in geheel Nederland (de referentie) waardoor er minder brandstof nodig is per eenheid geproduceerde elektriciteit. Hierdoor wordt de besparing aan primair brandstof door de wkk's in de glastuinbouw minder groot.

\section{Inkoop van warmte}

De reductie van het primair brandstofverbruik door de inkoop van warmte van derden is zowel in 2018 als in 2019 afgenomen en bedraagt in 2019 circa 66 miljoen $\mathrm{m}^{3}$ a.e (figuur 4.4). Deze daling komt door de grotere fractie duurzaam in de mix van centrale warmte-inkoop. In de periode 2014-2018 trad een lichte toename op.

De inkoop van warmte droeg in 2018 voor bijna 1 procentpunt bij aan de verbetering van de energieefficiëntie. De reductie van de $\mathrm{CO}_{2}$-emissie van de glastuinbouw (fossiel brandstofverbruik) door inkoop van warmte lag in 2019 met 0,15 Mton op een hoger in vergelijking met de reductie op nationaal niveau (primair brandstof) (0,12 Mton) (tabel 4.1). Dit komt door de extra uitstoot bij de centrales en de industrie door de productie van de warmte. Dit laatste telt wel mee op nationaal niveau (primair brandstof) en niet op sectorniveau (IPCC-methode).

Tabel 4.1 Reductie $\mathrm{CO}_{2}$-emissie door wkk en inkoop niet-duurzame warmte in $2019 \mathrm{v}$ )

\begin{tabular}{lrr} 
Wkk bron & $\mathrm{CO}_{2}$-reductie nationaal/primair brandstof \\
Wkk-tuinders & Mton & 1,60 \\
\hline Inkoop niet-duurzame warmte & 0,12 & $\mathbf{9 3}$ \\
\hline Totaal & $\mathbf{1 , 7 2}$ & $\mathbf{1 0 0}$ \\
\hline
\end{tabular}

v) Cijfers voorlopig. 


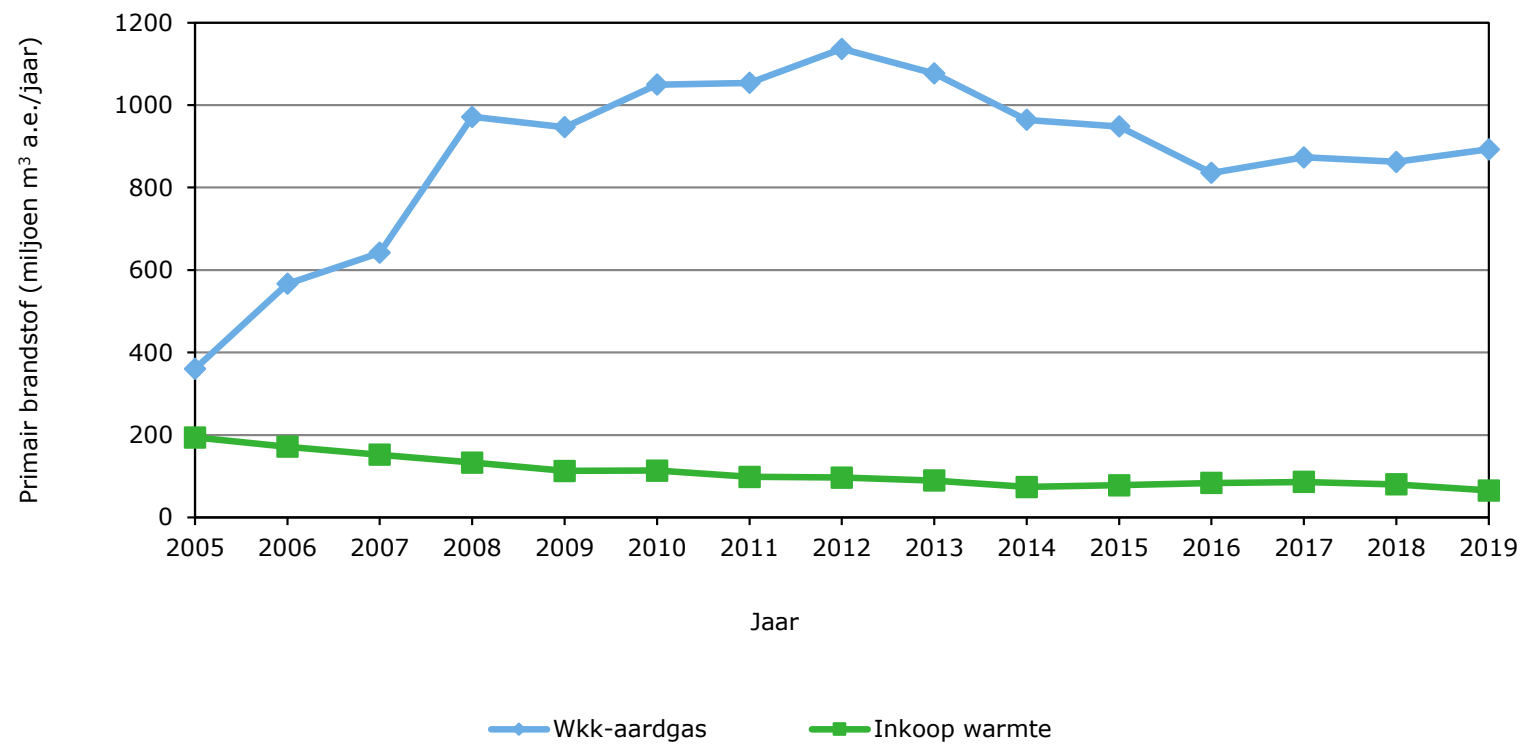

Figuur 4.4 Reductie primair brandstofverbruik door het gebruik van wkk door tuinders en door inkoop van niet-duurzame warmte a)

a) Cijfers 2019 voorlopig.

\subsection{Elektriciteitsbalans}

De elektriciteitsbalans bestaat uit de vier elementen: productie, verkoop, inkoop en consumptie. In deze paragraaf worden deze elementen achtereenvolgens behandeld. De elektriciteitsbalans van 2019 is weergegeven in figuur 4.5 en de ontwikkeling over de jaren heen is opgenomen in figuur 4.6.

De consumptie is berekend door de productie te verminderen met de verkoop en de inkoop er bij op te tellen. Eventuele statistische fouten in deze drie elementen werken hierbij door in de consumptie. De elektriciteitsbalans moet daardoor als een globale indicatie worden gezien.

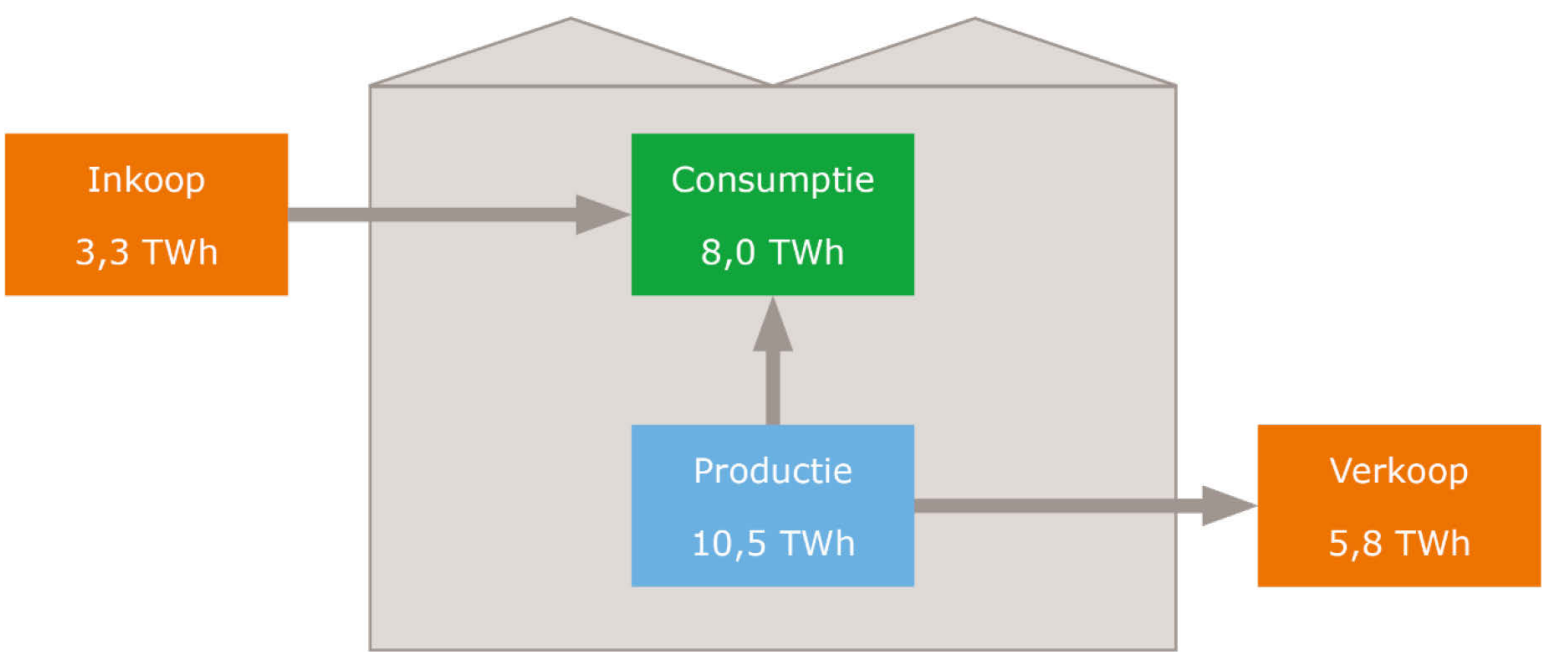

Figuur 4.5 Globale elektriciteitsbalans van de glastuinbouw in 2019 a)

a) Cijfers voorlopig. 


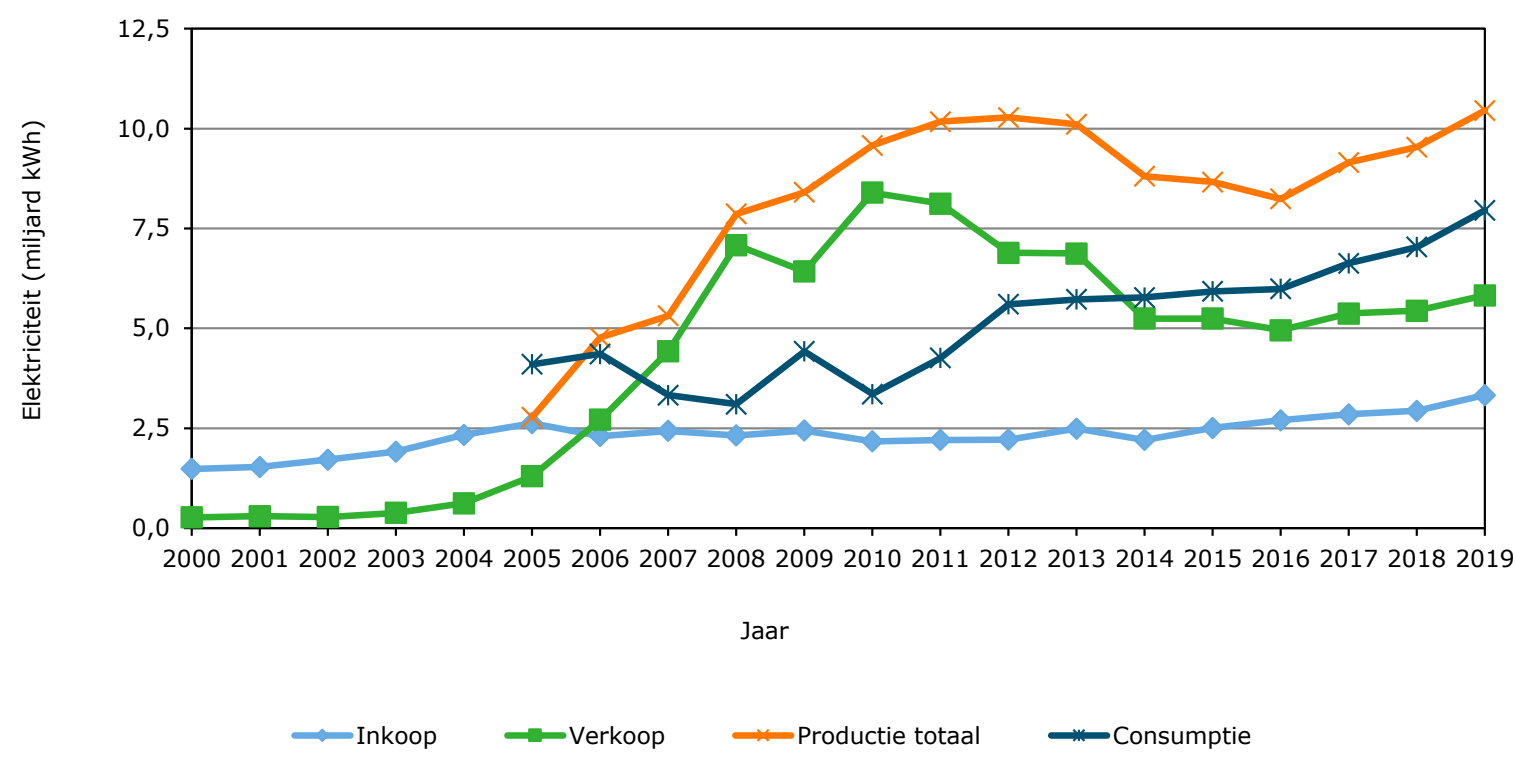

Figuur 4.6 Inkoop, verkoop, productie en consumptie van elektriciteit door de glastuinbouw a) a) De productie en de consumptie van voor 2005 zijn niet bekend; cijfers van 2019 zijn voorlopig.

\section{Productie}

De elektriciteitsproductie door de glastuinbouw lag in de jaren 2011-2013 boven de 10 miljard kWh. Hierna trad tot in 2016 een daling op. Dit kwam door de vermindering van het totale wkk-vermogen, gecombineerd met een gemiddeld kortere gebruiksduur. Na 2016 groeide de productie naar circa 10,4 miljard kWh in 2019. Dit is iets meer dan het niveau van de jaren 2011-2013. De groei kwam door de toename van de gebruiksduur door een gunstigere markt voor de verkoop van elektriciteit en toename van de elektriciteitsvraag in de glastuinbouw door de inzet van groeilicht. Behalve met aardgas-wkk produceerde de glastuinbouw een geringe hoeveelheid duurzame elektriciteit met bio-wkk en met zonnecellen (hoofdstuk 3) (circa 52 miljoen kWh). De totale elektriciteitsproductie door de glastuinbouw voorzag in 2019 ruim $9 \%$ van de totale Nederlandse elektriciteitsconsumptie. Per $\mathrm{m}^{2}$ kas kwam de totale productie in 2019 uit op gemiddeld circa 108 kWh.

\section{Verkoop}

Ook de verkoop heeft vanaf 2016 een toename laten zien. Deze groei kwam door de verbeterde spark spread (paragraaf 2.6) waardoor productie van elektriciteit voor de verkoop aantrekkelijker werd. De verkoop bedroeg in 2019 circa 5,8 miljard kWh. Dit is gemiddeld $60 \mathrm{kWh}$ per $\mathrm{m}^{2} \mathrm{kas}$.

\section{Inkoop}

De inkoop van elektriciteit heeft in de periode 2014-2019 een stijgende trend laten zien. In 2014 bedroeg de inkoop circa 2,2 en in 2019 is dit circa 3,3 miljard kWh. Dit is een stijging met circa 50\% in 5 jaar. Deze ontwikkeling hangt samen met de toename van het areaal met groeilicht, maar vooral de intensivering van groeilicht $\left(\mathrm{W} / \mathrm{m}^{2}\right)$. Door toename van de belichtingsintensiteit en de begrenzing vanuit de warmtevraag op een glastuinbouwbedrijf kan niet alle benodigde elektriciteit zelf worden opgewekt met wkk. Het resterende deel wordt dan ingekocht. Per $\mathrm{m}^{2}$ kas werd gemiddeld 34 kWh ingekocht

\section{Nettoleverancier}

Sinds 2006 is er jaarlijks meer elektriciteit verkocht dan er is ingekocht en is de glastuinbouw nettoleverancier van elektriciteit. De nettoverkoop nam toe tot ruim 6 miljard kWh in 2010. Daarna nam het saldo van verkoop minus inkoop af tot een niveau van circa 2,5 miljard kWh in 2019. Deze daling kwam door de toename van het eigen gebruik van de elektriciteitsproductie en de toename van de inkoop. Netto betekent dit voor 2019 een verkoop van 26 kWh per m² kas.

\section{Consumptie}

De elektriciteitsconsumptie (productie plus inkoop minus verkoop) van de sector groeide in 2019 tot naar schatting 8,0 miljard $\mathrm{kWh}$. Dit is $7 \%$ van de nationale consumptie. Per $\mathrm{m}^{2}$ kas bedroeg de 
consumptie gemiddeld $82 \mathrm{kWh}$. De consumptie vertoont sinds 2012 een toename en deze groei is sterker vanaf 2016.

De toename van de elektriciteitsconsumptie komt vooral door de toename van groeilicht (intensiteit en areaal) en in mindere mate door de inzet van duurzame energievoorzieningen, verdere optimalisering van het kasklimaat, mechanisatie en automatisering. Naast deze intensivering van de elektriciteitsconsumptie wordt er ook elektriciteitsbesparing gerealiseerd door bijvoorbeeld efficiëntere belichtingstechnieken, slimme regelingen en schaalvergroting. Uit de toename van de consumptie blijkt dat de intensivering van het elektriciteitsgebruik groter was dan de besparing.

In de elektriciteitsconsumptie werd in 2019 voor circa $58 \%$ voorzien door eigen productie met wkk, de resterende $42 \%$ werd ingekocht. In de periode vanaf 2015 ligt de mate waarin de glastuinbouw in zijn eigen elektriciteitsvraag voorziet tussen de 55 en 60\%. Voor het jaar 2015 nam het aandeel toe. De stabilisatie vanaf 2015 hangt samen met de begrenzing vanuit de warmtevraag op de glastuinbouwbedrijven waardoor de wkk's niet extra kunnen worden ingezet en de inzet van duurzame warmte ter vervanging van wkk.

\section{Warmtebenutting wkk}

Door wkk's wordt de vrijkomende warmte bij de elektriciteitsproductie grotendeels benut. Uit een eerdere studie (Smit en Van der Velden, 2008) is gebleken dat elektriciteitsproductie met een wkk bedrijfseconomisch niet uit kan zonder deze warmtebenutting. Ook bij de prijzen voor inkoop aardgas en verkoop elektriciteit in de periode 2017-2019 is dat het geval.

Bedrijven met belichting plannen wkk-draaiuren in blokken voor belichting. Buiten deze blokken kan elektriciteit worden verkocht als de warmte kan worden benut en de opbrengst van de elektriciteit opweegt tegen de productiekosten. Dit laatste geldt ook voor bedrijven zonder belichting. In de winter is er meer verkoop mogelijk omdat de warmtevraag in de winter groter is. Uit analyse van maandgegevens blijkt dat de elektriciteitsproductie in de jaren 2017 tot en met 2019 vooral plaatsvond in het koudere winter halfjaar (oktober $\mathrm{t} / \mathrm{m}$ maart). De meer en minder elektriciteitsproductie vindt vooral plaats in de maanden met respectievelijk een hogere en een lagere buitentemperatuur dan het jaar ervoor. In deze perioden kon de warmte dus in belangrijke mate worden benut. Uit het voorgaande kan worden afgeleid dat de extra elektriciteitsverkoop in de jaren 2017 tot en met 2019 grotendeels samenging met substantiële benutting van warmte afkomstig van wkk.

\section{Warmtedekking}

In de glastuinbouw is in 2019 circa $2.550 \mathrm{MW}_{\mathrm{e}}$ aan wkk-vermogen op circa $62 \%$ van het areaal in gebruik (paragraaf 4.2). Op dit areaal wordt gemiddeld $24 \mathrm{~m}^{3}$ a.e. per $\mathrm{m}^{2}$ kas warmte uit de wkk's benut. De ingekochte warmte van de centrales en de industrie (3,5 PJ; inclusief fractie duurzaam) werd in 2019 toegepast op circa 500 ha kassen (paragraaf 4.3). Op dit areaal werd gemiddeld zo'n $22 \mathrm{~m}^{3}$ a.e. per $\mathrm{m}^{2}$ ingekochte warmte gebruikt. De warmtedekking lag bij wkk dus iets hoger dan bij inkoop van warmte.

\section{Achtergronden}

De warmtedekking vanuit wkk of inkoop van warmte hangt naast de warmtevraag ook samen met het beschikbaar vermogen, de mate waarin actief wordt gehandeld en geschakeld op de energiemarkt en de beschikbaarheid van duurzame warmtebronnen en externe $\mathrm{CO}_{2}$.

De hoeveelheid warmte die per $\mathrm{m}^{2}$ wordt geconsumeerd vanuit wkk of wordt ingekocht ligt op een substantieel hoger niveau dan bij duurzame warmte ( $14 \mathrm{~m}^{3}$ a.e. per $\mathrm{m}^{2}$; paragraaf 3.4). Dit komt vooral door een grotere capaciteit van de warmtebron per $\mathrm{m}^{2}$ kas, invloeden van de energiemarkt en contractafspraken. Ook wordt op het areaal met inkoop van warmte in beperkte mate gebruikgemaakt van wkk's in vergelijking met het areaal met gebruik van duurzame warmte en komt er vanuit de wkk's $\mathrm{CO}_{2}$ beschikbaar voor het gewas en is inkoop van warmte vaak gecombineerd met de levering van externe $\mathrm{CO}_{2}$. 


\section{$5 \quad$ Reflectie}

\section{Inleiding}

In de voorgaande hoofdstukken zijn de ontwikkelingen van de energie-indicatoren van de glastuinbouw en van de achterliggende invloedsfactoren beschreven tot en met 2019. De $\mathrm{CO}_{2}$-emissie is beleidsmatig de belangrijkste indicator. $\mathrm{Er}$ bestaan diverse mogelijkheden om de $\mathrm{CO}_{2}$-emissie te reduceren (Van der Velden et al., 2018). Dit hoofdstuk beschouwt de stand van zaken, de realisatie van het doel voor 2020 en de beleidsmatige knelpunten voor verdere reductie van de $\mathrm{CO}_{2}$-emissie van de glastuinbouw op de korte en middellange termijn.

\section{Oorzaken ontwikkeling $\mathrm{CO}_{2}$-emissie}

De $\mathrm{CO}_{2}$-emissie van de glastuinbouw is in 2019 gestegen. Dit volgde op een periode van daling (20102014) en daarna een periode van stabilisatie (2014-2018). Achter de ontwikkeling van de $\mathrm{CO}_{2}$-emissie zitten invloedsfactoren; buitentemperatuur, areaal, verkoop elektriciteit, gebruik duurzame energie, inkoop van warmte, inkoop elektriciteit en energiegebruik per $\mathrm{m}^{2}$. Over de gehele periode 2010-2019 liet het gebruik van duurzame energie en inkoop elektriciteit een toename zien waardoor de $\mathrm{CO}_{2}$-emissie werd verlaagd. Ook is de jaarlijkse groei van deze twee factoren in deze periode sterker geworden. Inkoop van (niet duurzame) warmte liet over de gehele periode een afname zien. Deze ongunstige ontwikkeling voor de $\mathrm{CO}_{2}$-emissie kwam de laatste jaren door de toename van de fractie duurzaam bij de restwarmteprojecten. De fractie duurzaam telt mee bij duurzame energie en niet bij inkoop van warmte. Het totaal van inkoop duurzame warmte (hoofdstuk 3) en inkoop niet-duurzame warmte (hoofdstuk 4) nam in 2019 toe. Hierbij trad een verschuiving op van niet-duurzame naar duurzame warmte.

De andere factoren tonen een wisselend beeld per deelperiode. Het areaal kromp volgens de LBT tot in 2018 (paragraaf 2.1) en nam toe in 2019. Verkoop elektriciteit nam af tot in 2016 en nam daarna weer toe. Vooral door de toename van het areaal maar ook door de toename van de verkoop van elektriciteit nam de $\mathrm{CO}_{2}$-emissie in 2019 toe. Het energiegebruik per $\mathrm{m}^{2}$ bracht in 2010-2014 een substantiële reductie en in 2014-2018 een beperkte toename van de $\mathrm{CO}_{2}$-emissie met zich mee. In 2018 en 2019 had het energiegebruik per $\mathrm{m}^{2}$ vrijwel geen effect op de $\mathrm{CO}_{2}$-emissie. Hierbij is het relevant dat over de gehele periode 2010-2019 het warmtegebruik per $\mathrm{m}^{2}$ een daling en het elektriciteitsgebruik per $\mathrm{m}^{2}$ een toename liet zien.

De veranderingen zijn het gevolg van dynamiek binnen en tussen de invloedsfactoren. Buitentemperatuur, areaal en energieprijzen zijn invloedsfactoren die niet of heel beperkt door de convenantspartijen beïnvloed kunnen worden. De factoren verbonden aan de energievoorziening en de energievraag zijn wel te beïnvloeden. Deze factoren zijn het gebruik van duurzame energie, de inkoop van elektriciteit, de inkoop van warmte en het energiegebruik per $\mathrm{m}^{2}$ (intensivering, extensivering en besparing).

Technische correctie $\mathrm{CO}_{2}$-doel

In het Convenant is afgesproken dat indien de $\mathrm{CO}_{2}$-emissie door de externe factoren areaal en verkoop elektriciteit buiten een bandbreedte komt te liggen, in gezamenlijk overleg tussen overheid en sector besproken zal worden of de emissieruimte aangepast wordt. In 2017 is hiervoor een technische correctie van het $\mathrm{CO}_{2}$-doel overeengekomen. De actuele verwachting voor 2020 is dat het areaal en de verkoop van elektriciteit groter zal zijn dan de verwachting waarop de technische correctie uit 2017 is gebaseerd (Van der Velden en Smit, 2020b). Hierdoor ligt de $\mathrm{CO}_{2}$-emissie naar verwachting boven de overeengekomen bandbreedte behorende bij het $\mathrm{CO}_{2}$-doel voor 2020 na technische correctie. Dit betekent dat de convenantspartijen kunnen besluiten om een mogelijke nieuwe technische correctie van de $\mathrm{CO}_{2}$-emissieruimte van de glastuinbouw voor 2020 door te voeren. 


\section{Verwachting realisatie doel 2020}

In 2019 bedraagt de $\mathrm{CO}_{2}$-emissie van de glastuinbouw voor temperatuurcorrectie 5,9 Mton. $\mathrm{Na}$ temperatuur correctie is dit 6,0 Mton. De verwachting is dat dit in 2020 weinig zal veranderen (Van der Velden en Smit, 2020b). Uitgaande van het actuele doel van 4,6 Mton voor 2020 zal de $\mathrm{CO}_{2}-$ emissie in 2020 substantieel hoger liggen. De $\mathrm{CO}_{2}$-emissie in 2020 zal naar verwachting onder het oorspronkelijke doel van 6,2 Mton uit 2014 - voor technische correctie - komen te liggen. Om een uitspraak te kunnen doen over het realiseren van het doel voor 2020 zal er duidelijkheid moeten zijn over een mogelijke nieuwe technische correctie door de convenantspartijen.

Knelpunten verdere reductie $\mathrm{CO}_{2}$-emissie

Voor verdere reductie van de $\mathrm{CO}_{2}$-emissie van de glastuinbouw is het van belang dat het energiegebruik per $\mathrm{m}^{2}$ vermindert, wkk op aardgas minder wordt gebruikt en dat daarvoor duurzame energie, inkoop van warmte, inkoop elektriciteit en externe $\mathrm{CO}_{2}$ in de plaats komen. Deze elementen dienen in samenhang te worden bezien. Dit kan gezien worden als 'het waterbed'. Wordt ergens druk gegeven, dan komt de rest ook in beweging. Als bijvoorbeeld de aardgas- en/of elektriciteitskosten veranderen, dan wijzigt de inzet van wkk en volgt een verandering van de inzet van duurzame energie. Dit wordt gedempt door de vereisten van de teelt, de bestaande energievoorzieningen en de mate waarin ondernemers reageren op tactisch niveau. De samenhang bepaalt ook strategische beslissingen voor de langere termijn voor de energietransitie, investeringsbeslissingen en samenwerkingsverbanden.

Voor de verdere reductie van de $\mathrm{CO}_{2}$-emissie bestaan er beleidsmatige knelpunten die aandacht behoeven. Hierbij is het relevant dat er binnen de glastuinbouwsector grote verschillen bestaan tussen bedrijven, gewassen, regio's en ondernemers. Denk hierbij voor de gewassen aan intensieve en extensieve teelten met meer en minder mogelijkheden voor energiebesparing en inzet van energievoorzieningsopties zonder $\mathrm{CO}_{2}$-emissie. Tussen regio's bestaat er onder andere verschil in technisch potentieel van energievoorzieningsopties zonder $\mathrm{CO}_{2}$-emissie en in het aanbod van externe $\mathrm{CO}_{2}$. Tussen ondernemers bestaat er bijvoorbeeld verschil in wijze van afzet (jaarrond, partijmatig), bedrijfsomvang en opvolging.

\section{Exploitatieresultaat wkk}

Het gebruik van wkk kent vanuit de actuele aardgas- en elektriciteitsprijzen een gunstig exploitatie vooruitzicht. Met name voor bestaande installaties (paragraaf 2.6 en hoofdstuk 4). Dit geldt zowel voor de productie van elektriciteit voor de verkoop als voor het eigen gebruik door de glastuinbouw. Bovendien heeft een deel van de glastuinbouwbedrijven inkoop van aardgas en verkoop en inkoop van elektriciteit (inkoop en verkoop) voor een aantal jaren vooruit gecontracteerd. Hierdoor zal het exploitatieresultaat voor wkk naar verwachting voorlopig gunstig blijven.

Hiernaast is door de verhoging van de ODE op inkoop elektriciteit in 2018 en vooral 2019, het exploitatieresultaat voor de productie van elektriciteit voor eigen gebruik verbeterd. Daardoor stimuleert de ODE het gebruik van wkk voor de productie van elektriciteit voor eigen gebruik (Van der Velden et al., 2020). De eigen productie is vooral relevant voor bedrijven met een grote elektriciteitsvraag oftewel met belichting. De inzet van wkk voor de elektriciteitsproductie wordt begrensd vanuit de warmtevraag van de bedrijven. Hiermee samenhangend remt de eigen productie van elektriciteit de warmtebesparing op de bedrijven met belichting. Door het voorgaande is het gebruik van wkk zowel voor de verkoop als de eigen productie van elektriciteit een belemmering voor het gebruik van energievoorzieningsopties zonder $\mathrm{CO}_{2}$-emissie maar ook voor de verdere warmtebesparing op de bedrijven met belichting. Beiden zijn een rem op de toekomstige reductie van de $\mathrm{CO}_{2}$-emissie van de glastuinbouw.

\section{Energieprijzen}

De prijs die voor inkoop energie wordt betaald, bestaat uit een drietal componenten: commodity, diensten (transport en capaciteit) en heffingen. De prijs die de verkoop van energie oplevert betreft de commodityprijs. De heffingen en dienstenkosten komen bij verkoop voor rekening van de afnemer en zijn geen opbrengsten voor de producent. De commodityprijzen worden bepaald op de energiemarkt en zijn afhankelijk van nationale en internationale ontwikkelingen. De kosten voor heffingen worden bepaald door overheidsbeleid en de dienstenkosten worden deels bepaald door overheidsbeleid. 
Sturing aan het gebruik van wkk kan dus niet op de commodityprijs maar wel op de heffingen en dienstenkosten op inkoop energie en niet op de verkoop van energie. De dienstenkosten zijn een vergoeding voor de kosten voor tansport en de capaciteit van de brandstof of energie die geleverd wordt. Een dergelijke kostentoerekening is niet echt een sturingselement (Witmond et al., 2020).

\section{Heffingen}

Het exploitatieresultaat van energievoorzieningsopties zonder $\mathrm{CO}_{2}$-emissie kan verbeteren door verhoging van de bestaande heffingen voor inkoop aardgas en verlaging of afschaffing van de heffingen op inkoop elektriciteit. Hierdoor wordt de inkoop van aardgas afgeremd en de inkoop van elektriciteit gestimuleerd. De bestaande heffingen zijn de Energiebelasting (EB) en de Opslag duurzame Energie (ODE) en worden beiden geheven op inkoop aardgas en inkoop elektriciteit. Door deze heffingen wordt de warmte- en elektriciteitsbesparing weliswaar gestimuleerd maar door de ODE op elektriciteit wordt de energievoorzieningsoptie zonder $\mathrm{CO}_{2}$-emissie inkoop elektriciteit geremd. Het fiscale regime rond energie bevat nu belemmerende elementen voor de transitie naar een energievoorziening zonder $\mathrm{CO}_{2}$-emissie (Van der Velden et al., 2020). Kijkend naar de kenmerken van de energievraag en -voorziening van de glastuinbouw en de ambities ligt hier een optie voor aanpassing.

Naast of in plaats van de bestaande heffingen zou ook een generieke $\mathrm{CO}_{2}$-heffing op fossiele brandstoffen kunnen worden ingevoerd. Ook hierdoor wordt de inkoop van aardgas geremd en de inkoop van elektriciteit gestimuleerd. Indirect wordt elektriciteit geproduceerd met fossiele brandstof dan duurder ten opzichte van duurzame elektriciteit. Een dergelijke heffing kan ook een belangrijk neveneffect hebben bij invoering in Nederland alleen, mede kijkend naar de bredere impact op andere sectoren. De energievoorziening zal voorlopig nog voor een belangrijk deel bestaan uit fossiele brandstoffen en wordt door een heffing op fossiele brandstof duurder en dat heeft een negatieve invloed op de concurrentiepositie van sectoren en op de kosten voor huishoudens. Dit laatste brengt met zich mee dat voor een dergelijke heffing alleen draagvlak gevonden kan worden bij brede toepassing op internationaal niveau.

Duurzame warmte, inkoop van warmte; aanbod, investeringen en externe partners Over geheel Nederland bezien is er in beginsel een ruim technisch aanbod van mogelijke duurzame warmte en inkoop van warmte (Van der Velden et al., 2018). Dit is echter niet voor alle bronnen in alle glastuinbouwregio's het geval. Denk hierbij aan aardwarmte en inkoop van warmte maar ook aan aanbod van externe $\mathrm{CO}_{2}$. Daarnaast brengt ontwikkeling en ontsluiting van de warmtebronnen hoge investeringen met zich mee. Om dergelijke investeringen gefinancierd te krijgen, is vaak samenwerking nodig met risicodragende projectpartners. Dit kan in de vorm van investering en exploitatie door de externe partner maar ook door gezamenlijke investering en exploitatie door glastuinbouwbedrijven en externe partners. Dergelijke samenwerkingsprojecten nemen toe waardoor een verschuiving optreed in de energievoorziening zonder $\mathrm{CO}_{2}$-emissie in eigen beheer naar gezamenlijke exploitatie met partijen van buiten de sector en volledige outsourcing. Externe partners hebben behoefte aan spreiding van het projectrisico waardoor meer glastuinbouwbedrijven en areaal wordt betrokken bij het project. Deze aspecten beïnvloeden de warmtedekking.

\section{Warmtedekking duurzame energie}

De warmtedekking door duurzame warmte per $\mathrm{m}^{2}$ kas is relatief laag (hoofdstuk 3 ) in vergelijking met die van wkk (hoofdstuk) 4 en inkoop van warmte (hoofdstuk 4). Dit geldt voor alle duurzame warmtebronnen, zowel bij eigen productie als bij inkoop van derden, en wordt voor een belangrijk deel veroorzaakt door de opzet van de Stimulering Duurzame Energie (SDE). De subsidie vanuit de SDE wordt bepaald op basis van de onrendabele top en de kosteneffectiviteit van de subsidie $\left(€ / \mathrm{kg} \mathrm{CO}_{2}\right) . \mathrm{Om}$ in aanmerking te komen voor de subsidie is een relatief gunstige kosteneffectiviteit nodig. Hiervoor is een lange gebruiksduur van de duurzame energiebron noodzakelijk. Hiermee samenhangend wordt een duurzame warmtebron ingezet op meerdere bedrijven met een relatief groot totaal areaal waardoor de capaciteit per $\mathrm{m}^{2}$ beperkt is en een lange gebruiksduur een lage warmtedekking wordt gerealiseerd. Ook vanuit het projectrisico en de financiering wordt er naar gestreefd om meer bedrijven en areaal te betrekken bij een project. Ook hierdoor is de warmtecapaciteit per $\mathrm{m}^{2}$ kleiner, de gebruiksduur langer en de warmtedekking lager. Tot slot kan ook het aanbod van duurzame warmte (bijvoorbeeld herwinning zonnewarmte) en een beperkte regelbaarheid van de duurzame warmtebron (bijvoorbeeld aardwarmte) beperkingen met zich meebrengen. 
De warmtedekking door duurzame warmte kan worden verbeterd door de gecombineerde inzet van meerdere bronnen op hetzelfde areaal. Voor een dergelijke tweede warmtebron met een kortere gebruiksduur bestaan mogelijkheden voor biobrandstof in de SDE. Een geïntegreerde inzet van meerdere bronnen met een gezamenlijke hoge dekking is echter geen element van de SDE-regeling. De opties worden afzonderlijk beoordeeld. Dit beperkt het perspectief van opties met een kortere gebruiksduur. Een andere mogelijkheid om de warmtedekking te verbeteren is seizoenswarmte-opslag waarbij in de zomerperiode geproduceerde duurzame warmte deels als laagwaardige warmte wordt opgeslagen in de bodem (aquifers) voor gebruik in de winterperiode. Dit vindt al plaats bij herwinning zonnewarmte (hoofdstuk 3) en kan ook worden toegepast bij andere duurzame warmtebronnen. Twee belangrijke elementen bij deze verschuiving van warmteaanbod is het elektriciteitsgebruik voor het opwaarderen en verpompen van grote volumes laagwaardige warmte en de mate waarin de opslag kan worden gerealiseerd zonder grote warmteverliezen.

Door de lage dekking zal het areaal waarop gebruik wordt gemaakt van duurzame warmte sneller uitkomen op het potentieel beschikbare areaal en zal het gebruik van duurzame warmte in de glastuinbouw op (korte) termijn tegen grenzen aan lopen. Ter illustratie: in 2019 werd reeds op circa $19 \%$ van het areaal glastuinbouw aardwarmte, warmte uit biobrandstof en zonnewarmte toegepast. Daarnaast werd op circa $5 \%$ van het areaal ingekochte niet duurzame warmte toegepast. Samen is dit 24\% terwijl deze 2 bronnen gezamenlijk maar circa 10\% van de totaal energievraag voor hun rekening nemen. De lage warmtedekking per $\mathrm{m}^{2}$ bij duurzame warmte is daardoor een belemmering om de $\mathrm{CO}_{2}$-emissie sterk te reduceren.

\section{Infrastructuur}

Duurzame warmte substitueert met het gebruik van aardgas-wkk. Het gebruik van duurzame warmte gaat daardoor samen met meer inkoop elektriciteit voor de belichting. Dit geldt ook bij inkoop van warmte. Voor inkoop elektriciteit en inkoop van warmte zijn lokale transportnetten nodig. Lokale transportnetten zijn voor elektriciteit in diverse regio's een knelpunt. In de actuele situatie belemmert de afwezigheid van infrastructuur voor het transport van energie met voldoende capaciteit de verdere toepassing van genoemde energievoorzieningsopties zonder $\mathrm{CO}_{2}$-emissie en dus verdere reductie van de $\mathrm{CO}_{2}$-emissie.

Voor nieuwe warmteleveringsprojecten dient de infrastructuur voor het transport van warmte daarom te worden ontwikkeld in samenhang met de capaciteit van het elektriciteitsnet.

Voor de ontwikkeling van aanbod van inkoop van warmte en het transport van deze warmte en van duurzame warmte is een toegesneden stimuleringskader nodig met regionaal maatwerk. Bovendien dient bij de ontwikkeling van de transportnetten voor warmte de capaciteit per $\mathrm{m}^{2}$ in combinatie met de gewenste hoge warmtedekking in ogenschouw te worden genomen en is het aanbod en transport van externe $\mathrm{CO}_{2}$ daarbij een belangrijk aandachtspunt.

\section{Externe $\mathrm{CO}_{2}$}

Noodzakelijk voor verdere toepassing van energievoorzieningen zonder $\mathrm{CO}_{2}$-emissie is de externe $\mathrm{CO}_{2}$-voorziening. Dit is een randvoorwaarde voor de omschakeling naar het gebruik van duurzame warmte en inkoop van warmte, zeker met een gewenste hoge warmtedekking. Bovendien kan er door externe $\mathrm{CO}_{2}$ aardgas worden bespaard door het vermijden van zomerstook voor eigen $\mathrm{CO}_{2}$-voorziening. In 2019 werd circa 0,7 Mton $\mathrm{CO}_{2}$ extern ingekocht (paragraaf 3.5). Voor de toekomstige behoefte in 2020 in de situatie zonder aardgasgebruik in de glastuinbouw is zo'n 1,8 tot 3,0 Mton nodig (Van der Velden en Smit, 2019). Dit is 2,5 tot ruim 4 keer meer dan de inkoop in 2019. Voor een verdere reductie van de $\mathrm{CO}_{2}$-emissie van de glastuinbouw is dus meer aanbod van betaalbare externe $\mathrm{CO}_{2}$ nodig. Een knelpunt hierbij is dat er (nog) geen stimuleringsmaatregelen zijn om het externe aanbod en het gebruik van externe $\mathrm{CO}_{2}$ te vergroten.

\section{Energiegebruik per $m^{2}$}

De ontwikkeling van het energiegebruik per $\mathrm{m}^{2}$ wordt bepaald door de achterliggende processen intensivering, extensivering en energiebesparing. Door intensivering neemt de energievraag en de $\mathrm{CO}_{2}$-emissie toe en door extensivering en energiebesparing neemt de energievraag en de $\mathrm{CO}_{2}$-emissie af (paragraaf 2.5) (Van der Velden en Smit, 2017). Intensivering en extensivering hangen primair 
samen met de marktvraag van glastuinbouwproducten en de ontwikkeling hiervan wordt dus vooral extern bepaald.

Voor het realiseren van energiebesparing zijn er vele opties. De belangrijkste hierbij is Het Nieuwe Telen (HNT). HNT oftewel selectieve inzet van energie wordt veel toegepast en vooral bij teelt zonder belichting (Van der Velden en Smit, 2017). Bij teelt met belichting is dit minder het geval en zijn er specifieke technische kennisvragen over bijvoorbeeld de ontwikkeling van led-licht, schermmaterialen en kasdekken en teeltkundige kennisvragen op gewasniveau. Bij dit laatste is er samenhang met de omschakeling van traditionele hogedruk natrium lampen naar led-licht waar minder elektriciteit voor nodig is.

Daarnaast hangt de toepassing van HNT samen met de warmtebenutting van de wkk. Bij gebruik van wkk is er naast elektriciteitsproductie ook warmteproductie. In paragraaf 4.6 is gebleken dat de warmteproductie met de wkk in belangrijke mate wordt benut. Bij de heffingen op energie is reeds aangegeven dat er EB en ODE wordt geheven op inkoop elektriciteit. Bovendien is de ODE op inkoop elektriciteit in 2019 sterk verhoogd. Dit stimuleert het gebruik van wkk voor de productie van elektriciteit voor eigen gebruik, vooral voor belichting (Van der Velden et al., 2020). Hierbij komt vanuit de wkk ook warmte ter beschikking die aangewend dient te worden. De toename van de ODE op elektriciteit is daardoor een rem op het realiseren van warmtebesparing en dus ook van HNT voor bedrijven met belichting. Voor verdere reductie van de $\mathrm{CO}_{2}$-emissie van de glastuinbouw door energiebesparing kan een verlaging en/of een gewijzigde tariefstructuur van de ODE een stimulans worden. 


\section{Conclusies}

$\mathrm{CO}_{2}$-emissie

- Na stabilisatie in de periode 2014-2018 is de $\mathrm{CO}_{2}$-emissie van de Nederlandse glastuinbouw in 2019 toegenomen met 0,2 Mton tot 5,9 Mton. Daarmee ligt de emissie 1,3 Mton boven het actuele doel voor 2020 (4,6 Mton). In vergelijking met het oorspronkelijke doel vóór de technische correctie uit 2017 van 6,2 Mton ligt de $\mathrm{CO}_{2}$-emissie in 2019 daar 0,3 Mton onder.

- De $\mathrm{CO}_{2}$-emissie van de teelt nam in 2019 met 0,1 Mton toe naar 4,3 Mton. Deze toename is minder dan bij de totale $\mathrm{CO}_{2}$-emissie doordat er meer elektriciteit verkocht werd.

- In 2019 is vooral de toename van het areaal door een verbeterde deelname aan de LBT van invloed geweest op de $\mathrm{CO}_{2}$-emissie. Daarnaast nam de $\mathrm{CO}_{2}$-emissie ook toe door meer verkoop van elektriciteit en minder inkoop van niet-duurzame warmte. De stijging van de $\mathrm{CO}_{2}$-emissie werd deels gedempt door groei bij duurzame energie en bij inkoop van elektriciteit.

- De $\mathrm{CO}_{2}$-emissie van de glastuinbouw lag in 2019 14\% onder het niveau van 1990. In geheel Nederland was dit 4\%. De glastuinbouw ligt bij de $\mathrm{CO}_{2}$-emissie dus voor op de nationale reductie.

- Het aandeel van aardgas in de energievoorziening van de glastuinbouw daalde in de periode 20102019 van $88 \%$ naar 78\%. Deze ontwikkeling komt vooral door de groei van duurzame energie en in minder mate door de groei van inkoop elektriciteit

\section{Energie-efficiëntie}

- De energie-efficiëntie is in 2019 met 1 procentpunt verslechterd naar 45\% ten opzichte van 1990.

- Dit kwam doordat de fysieke productie per $\mathrm{m}^{2}(-7 \%)$ in 2019 sterker daalde dan het primair brandstofverbruik per $\mathrm{m}^{2}(-3 \%)$. De vermindering van het primair brandstofverbruik per $\mathrm{m}^{2}$ hing vooral samen met de toename van het gebruik van duurzame energie. De daling van de fysieke productie per $\mathrm{m}^{2}$ hing vooral samen met de toename van het areaal.

- Over een langere periode bezien is de energie-efficiëntie vanaf 2010 tot 2018 min of meer stabiel.

- De stabilisatie na 2010 komt mede door het streven naar een hogere waarde van de glastuinbouwproducten en door productie in de winterperiode met belichting. De eerste ontwikkeling remt de ontwikkeling van de fysieke productie en de tweede doet het primair brandstofverbruik toenemen.

\section{Duurzame energie}

- Het gebruik van duurzame energie is in 2019 sterk toegenomen. Het absolute gebruik nam met $35 \%$ toe tot $10,0 \mathrm{PJ}$. Het aandeel in het totaal energiegebruik groeide van 7,4 naar 9,4\%.

- De groei van zowel het aandeel als van het absolute gebruik waren nog nooit zo groot en zat vooral bij inkoop duurzame warmte. Ook gebruik van biobrandstof en aardwarmte namen toe.

- In 2019 was aardwarmte de meest toegepaste duurzame energiebron, op afstand gevolgd door inkoop duurzame warmte, inkoop duurzame elektriciteit, biobrandstoffen en zonne-energie. Inkoop van warmte bestaat uit aardwarmte en warmte geproduceerd met biobrandstof.

- Het gebruik van duurzame energie bestond voor $87 \%$ uit warmte en $13 \%$ uit elektriciteit.

- De exploitatie van nieuwe projecten is vaker in handen van externe partijen. De glastuinbouw koopt dan duurzame warmte in. Dit betrof in 2019 aardwarmte of warmte uit biobrandstof.

- Voor geheel Nederland bedroeg het aandeel duurzame energie in 2019 8,7\%. Het aandeel in de glastuinbouw komt daarmee in 2019 voor het eerst hoger uit dan het landelijk aandeel.

- Het areaal met duurzame energie (exclusief de inkoop uit openbare netten) nam in 2019 toe naar ruim 2.100 ha. Dit is $22 \%$ van het totaal areaal glastuinbouw.

- Het gebruik van duurzame energie had in 2019 een positief effect op de $\mathrm{CO}_{2}$-emissie van ruim 0,5 Mton. Op de energie-efficiëntie was het effect ruim 5 procentpunten.

- Het gebruik van externe $\mathrm{CO}_{2}$ groeide in 2019 door et bijna 5\% tot 0,7 Mton. 


\section{Energiekosten en energiegebruik}

- De netto-energiekosten $\left(€ / \mathrm{m}^{2}\right)$ namen in 2019 af. De kosten voor de inkoop van energie daalden meer dan de opbrengsten van de verkoop.

- Het totaal energiegebruik nam na groei in de jaren 2014-2017 en een afname in 2018, in 2019 wederom toe tot $106,8 \mathrm{PJ}$ en bestond voor circa $74 \%$ uit warmte en voor circa $26 \%$ uit elektriciteit. Daarbij trad evenals in eerdere jaren een verschuiving op van warmte naar elektriciteit.

- Na een toename van het energiegebruik per $\mathrm{m}^{2}$ in de periode 2014-2018 (+7\%) trad in 2019 een daling op van $2 \%$. De warmteconsumptie daalde $(-4 \%)$ en de elektriciteitsconsumptie steeg $(+5 \%)$.

Warmtekrachtkoppeling, elektriciteitsbalans en inkoop van warmte

- De elektriciteitsproductie bedroeg in 2019 10,5 miljard kWh. Dit is 9\% van de nationale consumptie. Niet eerder werd er zoveel elektriciteit geproduceerd door de glastuinbouw. De consumptie van de productie steeg naar 4,6 miljard en de verkoop naar 5,8 miljard kWh.

- De gemiddelde gebruiksduur van de wkk's nam sinds 2016 met bijna een kwart toe en bedroeg in 2019 circa 4.100 uur. Dit komt door de verbeterde spark spread.

- In 2019 bedroeg het totaal vermogen van de wkk's circa $2.550 \mathrm{MW}_{\mathrm{e}}$ en op circa $62 \%$ van het areaal is wkk in gebruik.

- Door de wkk's lag in 2019 de $\mathrm{CO}_{2}$-emissie van de glastuinbouw 1,6 Mton hoger en van elektriciteitscentrales 2,5 Mton lager. Op nationaal niveau werd zo 0,9 Mton $\mathrm{CO}_{2}$-emissie vermeden.

- De consumptie van elektriciteit neemt al jaren toe en bedroeg in 2019 circa 8 miljard kWh. Dit is 6\% van de nationale consumptie. De groei hangt samen met de toename van de belichting.

- Ook de inkoop van elektriciteit neemt al jaren toe en bedroeg in 2019 3,3 miljard kWh.

- Inkoop van warmte (exclusief duurzame warmte) nam in 2019 met 0,3 PJ af naar 2,3 PJ. De daling komt door de grotere fractie duurzaam in de geleverde warmte, die meetelt bij duurzame energie.

- Inkoop van warmte had in 2019 een positief effect op de $\mathrm{CO}_{2}$-emissie van 0,12 Mton.

Knelpunten verdere reductie $\mathrm{CO}_{2}$-emissie

Voor verdere reductie van de $\mathrm{CO}_{2}$-emissie van de glastuinbouw zijn de volgende beleidsmatige knelpunten geïdentificeerd:

- Het gebruik van de energievoorzieningsopties zonder $\mathrm{CO}_{2}$-emissie, duurzame warmte, inkoop van warmte en inkoop elektriciteit wordt belemmerd door het actueel gunstige bedrijfseconomisch perspectief voor wkk, maar ook door de verhoging van ODE op elektriciteit.

- De warmtedekking door duurzame warmte is relatief laag en neemt de laatste jaren af, terwijl het totaal gebruik van duurzame warmte groeit. Hierdoor zal het gebruik van duurzame warmte op termijn tegen grenzen aanlopen. Dit komt vooral door de structuur van de SDE en het spreiden van projectrisico's door exploitanten, tuinders en externe partners.

- Voor toename van het gebruik van de energievoorzieningsopties zonder $\mathrm{CO}_{2}$-emissie is infrastructuur voor warmte, elektriciteit en externe $\mathrm{CO}_{2}$ nodig met voldoende capaciteit op regionaal niveau. Een toegesneden stimuleringskader is hierbij van groot belang.

- Het realiseren van warmtebesparing door bijvoorbeeld HNT wordt op bedrijven met belichting geremd door de ODE op elektriciteit. Bovendien zijn er specifieke technische kennisvragen en teeltkundige kennisvragen op gewasniveau. 


\section{Literatuur en websites}

Brief van de Staatssecretaris van Economische Zaken, de heer Martijn van Dam, aan de voorzitter van de Tweede Kamer betreffende Evaluatie $\mathrm{CO}_{2}$-suring in de glastuinbouw, dd. 6 juli 2017.

Convenant $\mathrm{CO}_{2}$ emissieruimte binnen het $\mathrm{CO}_{2}$ sectorsysteem glastuinbouw voor de periode 20132020. 2011.

Hernieuwbare energie in Nederland t/m 2019, CBS, Den Haag, 2020.

Hoek, T. en S. Schlatmann, Inventarisatie nieuwe gasmotoren. Notitie. BleuTerra, 2020.

Klimaatakkoord, Den Haag 28 juni 2019; paragraaf 4.6 Glastuinbouw.

Meerjarenafspraak Energietransitie Glastuinbouw 2014-2020, Den Haag, 2014.

Velden, N. van der en P. Smit, Groei elektriciteitsconsumptie glastuinbouw; Hoe verder?. Rapport 2013-022. LEI Wageningen UR, 2013.

Velden, N. van der en P. Smit, Prognose $\mathrm{CO}_{2}$-emissie glastuinbouw 2020. Rapport 2016-067. Wageningen Economic Research, 2016.

Velden, N. van der en P. Smit, Effect intensivering, extensivering en energiebesparing op $\mathrm{CO}_{2}$-emissie Nederlandse glastuinbouw. Rapport 2017-060. Wageningen Economic Research, 2017

Velden, N.J.A. van der, P.X. Smit en J.S. Buurma, Prognoses $\mathrm{CO}_{2}$-emissie glastuinbouw 2030. Rapport 2018-056. Wageningen Economic Research, 2018.

Velden, N.J.A. van der en P.X. Smit, $\mathrm{CO}_{2}$-behoefte glastuinbouw 2030. Rapport 2019-074. Wageningen Economic Research, 2019.

Velden, N.J.A. van der, P.X. Smit en R.W van der Meer, Tariefstijging ODE inkoop elektriciteit: effecten op kosten en $\mathrm{CO}_{2}$-emissie glastuinbouw. Rapport 2020-044. Wageningen Economic Research, 2020.

Velden, N.J.A. van der en P.X. Smit, Protocol Energiemonitor Glastuinbouw; Versie tot en met 2019. Nota 2020-109a. Wageningen Economic Research, 2020a.

Velden, N.J.A. van der en P.X. Smit, Raming $\mathrm{CO}_{2}$-emissie glastuinbouw 2020. Rapport 2020-110. Wageningen Economic Research, 2020b.

Witmond, B, S. van der Kooij, H. Silvis, T. Vellinga, N. van der Velden, J. Reijs, W. Bruil, Advies en onderzoek 'Individuele afrekenmiddelen klimaatopgave in de landbouw'. Ecorys, Wageningen Economic Research en Instituut voor Agrarisch Recht, 2020.

WKK Barometer, Marktpositie wkk voorjaar 2020, BleuTerra Energy Experts, april 2020. 


\section{Bijlage 1 Definities, methode en bronnen}

\section{B1.1 Definities}

Protocol

De definities, methodiek en bronnen zijn vastgelegd in het Protocol Energiemonitor Glastuinbouw (Van der Velden en Smit, 2019) en worden in deze bijlage op hoofdlijnen toegelicht.

\section{Definities van indicatoren}

De energie-efficiëntie is het primair brandstofverbruik per eenheid product van de productieglastuinbouw, uitgedrukt in procenten van het niveau in het basisjaar.

De $\mathrm{CO}_{2}$-emissie wordt uitgedrukt in Mton per jaar en wordt bepaald volgens de IPCC-methode en heeft betrekking op de gehele glastuinbouwsector. Onderscheid wordt gemaakt naar de totale $\mathrm{CO}_{2}$-emissie van de sector en de $\mathrm{CO}_{2}$-emissie van de teelt (exclusief verkoop elektriciteit uit aardgasgestookte wkk).

Het aandeel duurzame energie is het quotiënt van de gebruikte hoeveelheid duurzame energie en het totale netto-energiegebruik (inkoop minus verkoop) in de gehele glastuinbouw, uitgedrukt in procenten.

De definities van de indicatoren verschillen ten aanzien van het areaal glas en het begrip energie.

\section{Areaal}

De glastuinbouw omvat het areaal productieglastuinbouw en het areaal uitgangsmateriaal (figuur B.1). De productieglastuinbouw bestaat uit de subsectoren groente, bloemen en potplanten. Het uitgangsmateriaal betreft de teelt van zaden en stek en de opkweek van jonge planten.

Uitgangsmateriaal wordt gezien als toelevering (binnen en buiten de glastuinbouw) en niet als primaire productie. Daarom blijft het areaal met uitgangsmateriaal buiten beschouwing bij de energieefficiëntie. De $\mathrm{CO}_{2}$-emissie heeft betrekking op de gehele glastuinbouw, inclusief het areaal uitgangsmateriaal.

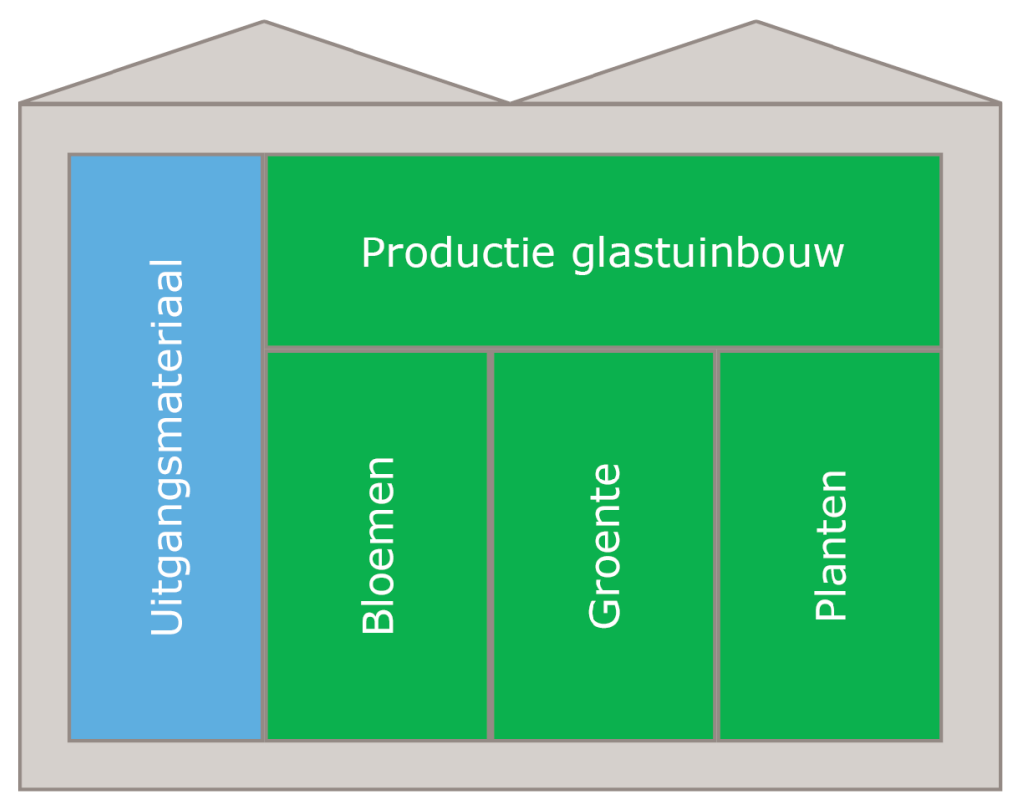

Figuur B.1 Schematische weergave areaal glastuinbouw en productieglastuinbouw 


\section{Energie}

Het energiegebruik in de glastuinbouw omvat meerdere soorten (figuur B.2). Aardgas, overig fossiel, warmte en elektriciteit worden ingekocht en elektriciteit en warmte verkocht. Duurzame energie wordt ingekocht, geproduceerd en verkocht. Dit alles is op verschillende wijzen te sommeren.

Sommatie van de afzonderlijke energiesoorten op basis van energie-inhoud resulteert in het kengetal totaal energiegebruik. De verkoop van energie wordt hierbij in mindering gebracht.

Voor het primair brandstofverbruik wordt de hoeveelheid fossiele brandstof bepaald die nodig is voor de productie van de afzonderlijke energiesoorten. Aardgas en overige fossiele brandstoffen zijn primaire brandstoffen. De inkoop van elektriciteit wordt herleid tot de hoeveelheid brandstof die daarvoor nodig is in een gemiddelde Nederlandse elektriciteitscentrale zonder warmtelevering. Voor de verkoop van elektriciteit geldt hetzelfde, maar dit wordt in mindering gebracht. De ingekochte warmte komt van elektriciteitscentrales (restwarmte), industrie en van energiebedrijven. Door de gecombineerde productie van elektriciteit en warmte ligt de elektriciteitsproductie lager. Voor de geleverde warmte wordt de extra hoeveelheid brandstof berekend die nodig is om de derving van de elektriciteitsproductie te compenseren.

De $\mathrm{CO}_{2}$-emissie wordt bepaald op basis van de IPCC-methode. Hierbij wordt alleen de werkelijk verstookte fossiele brandstof op glastuinbouwbedrijven in beschouwing genomen. Onderscheid wordt gemaakt naar de totale $\mathrm{CO}_{2}$-emissie en de $\mathrm{CO}_{2}$-emissie van de teelt. De totale $\mathrm{CO}_{2}$-emissie heeft betrekking op alle fossiele brandstoffen, inclusief de productie van elektriciteit op de glastuinbouwbedrijven. De $\mathrm{CO}_{2}$-emissie van de teelt is de totale $\mathrm{CO}_{2}$-emissie, verminderd met de emissie die gerelateerd is aan door de glastuinbouw verkochte elektriciteit, geproduceerd met aardgasgestookte wkk.

Het primair brandstofverbruik is de grondslag voor de energie-efficiëntie. De $\mathrm{CO}_{2}$-emissie wordt bepaald op basis van het werkelijke gebruik van fossiele brandstoffen (IPCC-methode).

Het totale energiegebruik wordt gebruikt voor het bepalen van het aandeel duurzame energie. Netto wil zeggen inkoop minus verkoop.

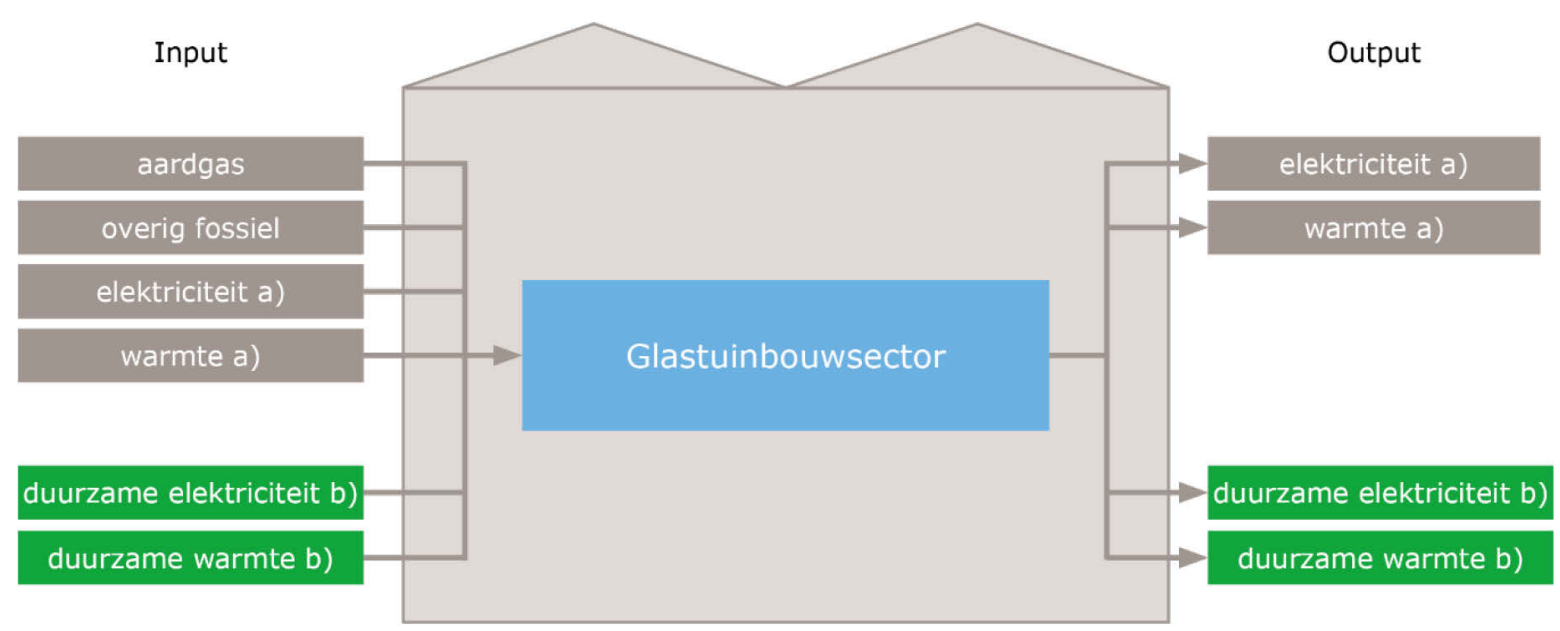

Figuur B.2 Energie-input en -output van de glastuinbouwsector

a) Fossiele bron.

b) Hernieuwbare of duurzame bron.

\section{Duurzame energie}

Duurzame energie omvat energie uit zon, wind, waterkracht, aardwarmte en biobrandstof via een hernieuwbaar proces. Hernieuwbaar betekent dat er geen fossiele brandstof wordt gebruikt en er netto geen $\mathrm{CO}_{2}$-emissie ontstaat. Het aandeel duurzame energie heeft betrekking op het gebruik in de glastuinbouw. Duurzaam geproduceerde energie voor gebruik buiten de sector telt niet mee. 
Voorbeelden hiervan zijn op biobrandstof gestookte wkk's, waarvan de geproduceerde elektriciteit (deels) wordt verkocht buiten de sector of aardwarmte dat wordt verkocht buiten de sector. Verkoop van duurzame energie binnen de sector telt wel mee, evenals ingekochte duurzame elektriciteit en duurzame warmte van buiten de sector.

Bij het bepalen van het totale energiegebruik in de glastuinbouw op basis van energie-inhoud telt de duurzame energie wel mee. Dit is niet het geval bij het bepalen van het primair brandstofverbruik en de $\mathrm{CO}_{2}$-emissie.

\section{Temperatuurcorrectie}

Het energiegebruik verschilt van jaar tot jaar, mede door verschillen in buitentemperatuur. Het primair brandstofverbruik, en dus ook de energie-efficiëntie, wordt hiervoor gecorrigeerd. Bij het totale energiegebruik, het aandeel duurzame energie en de $\mathrm{CO}_{2}$-emissie vindt geen temperatuurcorrectie plaats.

\section{B1.2 Methode en bronnen}

Voor het kwantificeren van de indicatoren moeten de totale energie-input en -output van de glastuinbouw en de productieglastuinbouw opgesplitst naar afzonderlijke energiesoorten worden vastgesteld (figuur B.2). Voor de energie-efficiëntie betreft dit ook de fysieke productie. Daarnaast is informatie nodig voor het opstellen van de elektriciteitsbalans.

De belangrijkste informatiebronnen zijn:

- energieregistraties van het Milieu Project Sierteelt (MPS)

- energieregistraties van Greelinqdata

- energieregistraties van groepen tuinders en adviseurs

- energieregistraties van groentebedrijven van het Bedrijveninformatienet van het Wageningen Economic Research

- inkoop van warmte van de leveranciers

- elektrisch vermogen van en elektriciteitsproductie door wkk's van energiebedrijven en tuinders vanuit de inventarisatie door BlueTerra

- gebruiksduur van wkk van tuinders op basis van informatie van energiebedrijven, groepen tuinders en het Bedrijveninformatienet van Wageningen Economic Research

- veilingomzetten bloemen en planten van de FloraHolland en Plantion

- prijsinformatie bloemen en planten van FloraHolland

- fysieke productie vruchtgroenten van het Bedrijveninformatienet van Wageningen Economic Research, accountants, telersverenigingen, groepen tuinders en adviseurs

- areaalgegevens en informatie over het gebruik van wkk door tuinders uit de Landbouwtelling, gepubliceerd door het Centraal Bureau voor de Statistiek (CBS)

- areaalgegevens belichting vruchtgroenten van adviseurs en telersverenigingen

- verkoopinformatie duurzame elektriciteit van energiebedrijven

- informatie over aardwarmteproductie van Dutch Association Geothermal Operators (DAGO);

- leveranciers van installaties en adviseurs.

\section{Energie-input en -output}

Figuur B.2 geeft de energie-input en -output van de glastuinbouw schematisch weer. MPS, Greelinqdata en andere bronnen bieden informatie over het energiegebruik per energiesoort in de subsectoren groente, bloemen, potplanten en uitgangsmateriaal. De bedrijfsgegevens van deze bronnen zijn ingedeeld naar gewas(groep) conform de Landbouwtelling van het CBS. Met behulp van de areaalgegevens per gewas(groep) van de Landbouwtelling is de energie-informatie per gewas(groep) geaggregeerd naar sectorniveau. Daarnaast is informatie beschikbaar over de warmteinkoop door de glastuinbouw. 


\section{Wkk en elektriciteitsbalans}

De glastuinbouw produceert op grote schaal elektriciteit met wkk. De elektriciteitsproductie van deze installaties is het product van het totaal elektrisch vermogen in de glastuinbouw en de gemiddelde gebruiksduur.

Voor het in kaart brengen van een elektriciteitsbalans zijn de inkoop, verkoop en productie gekwantificeerd, waarna de elektriciteitsconsumptie is berekend. Bij dit laatste dient opgemerkt te worden dat de consumptie de sluitpost is waarin alle eventuele fouten bij het bepalen van de inkoop, verkoop en productie doorwerken. De informatie over de consumptie moet daardoor gezien worden als een globale indicatie.

\section{Inventarisatie duurzame energie}

Statistieken over het gebruik van duurzame energiebronnen zijn nog nauwelijks beschikbaar. Duurzame energie is in kaart gebracht middels een inventarisatie van de projecten. Voor inkoop duurzame elektriciteit is informatie verzameld over de verkoop aan de glastuinbouw bij energiebedrijven. Voor aardwarmte is gebruik gemaakt van informatie van DAGO.

\section{Fysieke productie}

De glastuinbouw brengt vele producten voort. De fysieke productie wordt uitgedrukt in verschillende eenheden: tomaten en paprika per kg, komkommers per stuk, bloemen per stuk of per bos en potplanten per stuk. Sommatie van deze eenheden vindt indirect plaats. Hierbij wordt uitgegaan van de totale omzet aan glastuinbouwproducten per jaar. Omzetverschillen tussen jaren hangen samen met mutaties in prijs en in fysieke productie. De fysieke productie wordt bepaald door de jaaromzet te corrigeren voor de gemiddelde prijsmutatie van de glastuinbouwproducten.

Bij de groente is beperkte informatie beschikbaar over jaaromzet en prijsmutaties. Daarom is voor deze subsector informatie over de ontwikkeling van de fysieke productie verzameld van de belangrijkste gewassen (tomaat, paprika en komkommer). Deze gewassen omvatten het overgrote deel van het areaal groente. 


\section{Bijlage 2 Kenmerken en energie-indicatoren glastuinbouw}

\begin{tabular}{|c|c|c|c|c|c|c|c|c|c|c|c|c|c|}
\hline Grootheid & Eenheid & 1980 & 1990 & 2000 & 2005 & 2010 & 2013 & 2014 & 2015 & 2016 & 2017 & 2018 & 2019v \\
\hline Areaal glastuinbouw & ha & 8.755 & 9.768 & 10.528 & 10.537 & 10.307 & 9.817 & 9.488 & 9.206 & 9.278 & 9.080 & 8.990 & 9.688 \\
\hline Areaal productieglastuinbouw & ha & 8.527 & 9.368 & 10.036 & 10.028 & 9.757 & 9.235 & 8.876 & 8.609 & 8.635 & 8.430 & 8.380 & 8.928 \\
\hline Buitentemperatuur $\mathrm{g}$ ) & graaddagen & 3.246 & 2.680 & 2.659 & 2.765 & 3.321 & 3.078 & 2.385 & 2.686 & 2.785 & 2.647 & 2.604 & 2.618 \\
\hline \multirow[t]{2}{*}{ Totaal energie a), c) } & $\mathrm{PJ}$ & - & - & 127,5 & 128,1 & 127,1 & 112,9 & 96,0 & 99,4 & 100,4 & 101,1 & 100,8 & 106,8 \\
\hline & $\mathrm{MJ} / \mathrm{m}^{2}$ & - & - & 1.211 & 1.216 & 1.233 & 1.150 & 1.011 & 1.080 & 1.082 & 1.113 & 1.122 & 1.102 \\
\hline \multirow[t]{2}{*}{ Primair brandstof b), d) } & $10^{6} \mathrm{~m}^{3}$ a.e. & 3.488 & 4.195 & 4.276 & 3.860 & 2.565 & 2.544 & 2.393 & 2.395 & 2.442 & 2.424 & 2.466 & 2.553 \\
\hline & $\mathrm{m}^{3}$ a.e. $/ \mathrm{m}^{2}$ & 40,9 & 44,8 & 42,6 & 38,5 & 26,3 & 27,5 & 27,0 & 27,8 & 28,3 & 28,7 & 29,4 & 28,6 \\
\hline Fysieke productie per $\mathrm{m}^{2} \mathrm{~b}$ ) & $\% 1990$ & - & 100 & 114 & 128 & 137 & 141 & 148 & 147 & 148 & 153 & 151 & 141 \\
\hline Energie-efficiëntie b), d) & $\% 1990$ & - & 100 & 84 & 67 & 43 & 44 & 41 & 42 & 43 & 42 & 44 & 45 \\
\hline \multirow[t]{2}{*}{ Fossiel brandstof totaal a), c) } & $10^{6} \mathrm{~m}^{3}$ a.e. & - & 3.808 & 3.710 & 3.596 & 4.502 & 3.847 & 3.163 & 3.213 & 3.172 & 3.214 & 3.175 & 3.296 \\
\hline & $\mathrm{m}^{3}$ a.e. $/ \mathrm{m}^{2}$ & - & 39,0 & 35,2 & 34,1 & 43,7 & 39,2 & 33,3 & 34,9 & 34,2 & 35,4 & 35,3 & 34,0 \\
\hline \multirow[t]{2}{*}{ Fossiel brandstof teelt a), c) } & $10^{6} \mathrm{~m}^{3}$ a.e. & - & 3.808 & 3.670 & 3.398 & 3.227 & 2.804 & 2.369 & 2.419 & 2.422 & 2.401 & 2.352 & 2.415 \\
\hline & $m^{3}$ a.e. $/ m^{2}$ & - & 39,0 & 34,9 & 32,3 & 31,3 & 28,6 & 25,0 & 26,3 & 26,1 & 26,4 & 26,2 & 24,9 \\
\hline \multirow[t]{2}{*}{$\mathrm{CO}_{2}$-emissie totaal a), c) } & Mton & - & 6,8 & 6,7 & 6,5 & 8,1 & 6,9 & 5,6 & 5,7 & 5,7 & 5,7 & 5,7 & 5,9 \\
\hline & $\% 1990$ & - & 100 & 97 & 94 & 118 & 100 & 82 & 84 & 83 & 84 & 83 & 86 \\
\hline $\begin{array}{l}\mathrm{CO}_{2} \text {-emissie totaal na temperatuur } \\
\text { correctie }\end{array}$ & Mton & - & 7,4 & 7,3 & 6,6 & 7,8 & 6,8 & 5,9 & 5,8 & 5,7 & 5,9 & 5,8 & 6,0 \\
\hline \multirow[t]{2}{*}{$\mathrm{CO}_{2}$-emissie teelt a), c) } & Mton & - & 6,8 & 6,6 & 6,1 & 5,8 & 5,0 & 4,2 & 4,3 & 4,3 & 4,3 & 4,2 & 4,3 \\
\hline & $\% 1990$ & - & 100 & 96 & 89 & 84 & 73 & 62 & 63 & 63 & 63 & 62 & 63 \\
\hline \multirow[t]{2}{*}{$\mathrm{CO}_{2}$-emissie Nederland f) } & Mton & - & 163,3 & 172,4 & 177,9 & 182,6 & 166,2 & 159,2 & 166,8 & 166,7 & 164,9 & 160,6 & 156,6 \\
\hline & $\% 1990$ & - & 100 & 106 & 109 & 112 & 102 & 98 & 102 & 102 & 101 & 99 & 94 \\
\hline Aandeel duurzaam a), c) & $\%$ & - & - & 0,1 & 0,5 & 1,9 & 2,9 & 4,2 & 4,9 & 5,4 & 6,6 & 7,4 & 9,4 \\
\hline Aandeel duurzaam Nederland f) & $\%$ & & & 1,6 & 2,5 & 3,9 & 4,8 & 5,5 & 5,8 & 6,0 & 6,6 & 7,4 & 8,7 \\
\hline
\end{tabular}


Bijlage 3 Energiegebruik glastuinbouw (totale glastuinbouwareaal en niet gecorrigeerd voor temperatuur) a)

\begin{tabular}{|c|c|c|c|c|c|c|c|c|c|c|c|c|c|}
\hline Energiesoort & Eenheid & 1980 & 1990 & 2000 & 2005 & 2010 & 2013 & 2014 & 2015 & 2016 & 2017 & 2018 & $2019 v$ \\
\hline Aardgas & miljoen $\mathrm{m}^{3}$ & 3.352 & 3.778 & 3.709 & 3.593 & 4.500 & 3.846 & 3.162 & 3.212 & 3.171 & 3.213 & 3.174 & 3.295 \\
\hline Overig fossiel b) & miljoen $\mathrm{m}^{3}$ a.e. & - & 30 & 1 & 3 & 2 & 1 & 1 & 1 & 1 & 1 & 1 & 1 \\
\hline Inkoop van warmte c) & PJ & 0 & 1,9 & 14,9 & 9,1 & 5,3 & 4.2 & 3,4 & 3,5 & 3,7 & 3,7 & 3,4 & 2,8 \\
\hline \multicolumn{14}{|l|}{ Elektriciteit } \\
\hline - inkoop totaal & miljoen $\mathrm{kWh}$ & - & - & 1.479 & 2.626 & 2.169 & 2.488 & 2.206 & 2.507 & 2.699 & 2.849 & 2.837 & 3.329 \\
\hline - wv groen & miljoen $\mathrm{kWh}$ & - & - & 0 & 55 & 175 & 140 & 150 & 210 & 260 & 530 & 400 & 370 \\
\hline - verkoop & miljoen kWh & - & - & 266 & 1298 & 8.397 & 6.873 & 5.244 & 5.245 & 4.953 & 5.372 & 5.439 & 5.826 \\
\hline - wv groen & miljoen kWh & - & - & - & - & 21 & 22 & 27 & 28 & 28 & 27 & 33 & 36 \\
\hline - netto-inkoop & miljoen kWh & - & - & 1.213 & 1.328 & -6.228 & -4.385 & -3.038 & -2.738 & -2.254 & -2.523 & -2.502 & -2.497 \\
\hline Duurzame energie & PJ & - & - & 0,1 & 0,6 & 2,4 & 3,3 & 4,0 & 4,9 & 5,4 & 6,7 & 7,4 & 10,0 \\
\hline Totaal energie & PJ & - & - & 136,7 & 128,1 & 127,1 & 112,9 & 96,0 & 99,4 & 100,4 & 101,1 & 100,8 & 106,8 \\
\hline Totaal fossiel & miljoen $\mathrm{m}^{3}$ a.e. & - & 3.808 & 3.710 & 3.596 & 4.502 & 3.847 & 3.163 & 3.213 & 3.172 & 3.214 & 3.175 & 3.296 \\
\hline
\end{tabular}

$v$ = voorlopige cijfers; - = cijfers niet beschikbaar

a) de verkoop van warmte komt voor sinds 2007 maar is in deze tabel niet opgenomen, omdat het een zeer beperkte hoeveelheid betreft; b) zware en lichte olie en propaan; c) exclusief inkoop duurzame warmte. 


\section{Bijlage 4 Gebruik en reductie $\mathrm{CO}_{2}$-emissie per duurzame energiebron en inkoop $\mathrm{CO}_{2}$}

\begin{tabular}{|c|c|c|c|c|c|c|c|c|c|c|c|c|c|}
\hline \multirow[t]{3}{*}{ Duurzame energiebron } & \multirow{2}{*}{\multicolumn{5}{|c|}{ Areaal c), aantal bedrijven c), vermogen c) en/of hoeveelheid }} & \multicolumn{8}{|c|}{ Reductie $\mathrm{CO}_{2}$-emissie (Mton) } \\
\hline & & & & & & \multicolumn{4}{|c|}{ sector/IPCC } & \multicolumn{4}{|c|}{ nationaal/primair brandstof } \\
\hline & 2010 & 2015 & 2017 & 2018 & $2019 v$ & 2010 & 2017 & 2018 & 2019v & 2010 & 2017 & 2018 & 2019v \\
\hline Aardwarmte & $\begin{array}{l}1 \text { bedrijf } \\
21 \text { ha }\end{array}$ & $\begin{array}{l}34 \text { bedrijven } \\
459 \text { ha }\end{array}$ & $\begin{array}{l}55 \text { bedrijven } \\
621 \text { ha }\end{array}$ & $\begin{array}{l}81 \text { bedrijven } \\
741 \text { ha }\end{array}$ & $\begin{array}{l}86 \text { bedrijven } \\
943 \text { ha }\end{array}$ & 0,015 & 0,161 & 0,195 & 0,231 & 0,014 & 0,145 & 0,177 & 0,201 \\
\hline \multicolumn{14}{|l|}{ Zonne-energie } \\
\hline - warmte a) & $\begin{array}{l}55 \text { bedrijven } \\
216 \text { ha }\end{array}$ & $\begin{array}{l}64 \text { bedrijven } \\
211 \text { ha }\end{array}$ & $\begin{array}{l}61 \text { bedrijven } \\
210 \text { ha }\end{array}$ & $\begin{array}{l}62 \text { bedrijven } \\
214 \text { ha }\end{array}$ & $\begin{array}{l}62 \text { bedrijven } \\
214 \text { ha }\end{array}$ & 0,042 & 0,044 & 0,044 & 0,044 & 0,014 & 0,017 & 0,018 & 0,019 \\
\hline - elektriciteit & $\begin{array}{l}1 \text { bedrijf } \\
8 \text { ha }\end{array}$ & $\begin{array}{l}3 \text { bedrijven } \\
65 \text { ha }\end{array}$ & $\begin{array}{l}51 \text { bedrijven } \\
223 \text { ha }\end{array}$ & $\begin{array}{l}62 \text { bedrijven } \\
257 \text { ha }\end{array}$ & $\begin{array}{l}101 \text { bedrijven } \\
358 \text { ha }\end{array}$ & 0 & 0 & 0 & 0 & $<0,001$ & 0,004 & 0,006 & 0,009 \\
\hline \multicolumn{14}{|l|}{ Biobrandstoffen } \\
\hline \multirow{2}{*}{$\begin{array}{l}\text { - warmte } \\
\text { - warmte plus elektriciteit b) }\end{array}$} & $\begin{array}{l}80 \text { ha } \\
4 \text { bedrijven }\end{array}$ & $\begin{array}{l}117 \text { ha } \\
4 \text { bedrijven }\end{array}$ & $\begin{array}{l}130 \text { ha } \\
5 \text { bedrijven }\end{array}$ & $\begin{array}{l}150 \text { ha } \\
6 \text { bedrijven }\end{array}$ & $\begin{array}{l}163 \text { ha } \\
6 \text { bedrijven }\end{array}$ & 0,009 & 0,027 & 0,031 & 0,049 & 0,009 & 0,026 & 0,030 & 0,047 \\
\hline & $\begin{array}{l}45 \mathrm{ha} \\
5 \mathrm{MWe}\end{array}$ & $\begin{array}{l}19 \mathrm{ha} \\
4 \mathrm{MW}_{\mathrm{e}}\end{array}$ & $\begin{array}{l}44 \mathrm{ha} \\
5 \mathrm{MWe}\end{array}$ & $\begin{array}{l}45 \mathrm{ha} \\
5 \mathrm{MWe}_{\mathrm{e}}\end{array}$ & $\begin{array}{l}45 \mathrm{ha} \\
5 \mathrm{MW}_{\mathrm{e}}\end{array}$ & 0,009 & 0,011 & 0,013 & 0,011 & 0,019 & 0,026 & 0,026 & 0,024 \\
\hline Inkoop duurzame elektriciteit & $17510^{6} \mathrm{kWh}$ & $20010^{6} \mathrm{kWh}$ & $53010^{6} \mathrm{kWh}$ & $40010^{6} \mathrm{kWh}$ & $370 \cdot 10^{6} \mathrm{kWh}$ & 0 & 0 & 0 & 0 & 0,082 & 0,235 & 0,174 & 0,157 \\
\hline \multicolumn{14}{|l|}{ Inkoop duurzame warmte } \\
\hline - centraal & - & - & - & - & - & 0,012 & $<0,001$ & 0,006 & 0,040 & 0,007 & $<0,001$ & 0,006 & 0,040 \\
\hline - decentraal & $\begin{array}{l}6 \text { bedrijven } \\
30 \text { ha }\end{array}$ & $\begin{array}{l}7 \text { bedrijven } \\
33 \text { ha }\end{array}$ & $\begin{array}{l}7 \text { bedrijven } \\
33 \text { ha }\end{array}$ & $\begin{array}{l}9 \text { bedrijven } \\
68 \text { ha }\end{array}$ & $\begin{array}{l}77 \text { bedrijven } \\
421 \text { ha }\end{array}$ & 0,008 & 0,014 & 0,035 & 0,097 & 0,097 & 0,013 & 0,034 & 0,096 \\
\hline Inkoop duurzaam gas & $110^{6} \mathrm{~m}^{3}$ & $110^{6} \mathrm{~m}^{3}$ & $110^{6} \mathrm{~m}^{3}$ & $110^{6} \mathrm{~m}^{3}$ & $1 \cdot 10^{6} \mathrm{~m}^{3}$ & 0,002 & 0,002 & 0,002 & 0,002 & 0,002 & 0,002 & 0,002 & 0,002 \\
\hline Totaal duurzame energie & d) & d) & d) & d) & d) & 0,096 & 0,259 & 0,326 & 0,474 & 0,159 & 0,469 & 0,473 & 0,594 \\
\hline Inkoop $\mathrm{CO}_{2}$ & 0,51-0,54 Mton & 0,51-0,55 Mton & 0,56-0,60 Mton & 0,65-0,69 Mton & 0,69-0,73 Mton & $\#$ & $\#$ & $\#$ & $\#$ & $\#$ & \# & \# & \# \\
\hline
\end{tabular}


Bijlage 5 Gebruik en reductie $\mathrm{CO}_{2}$-emissie wkk en inkoop van warmte

\begin{tabular}{|c|c|c|c|c|c|c|c|c|c|c|c|c|c|}
\hline \multirow[t]{3}{*}{ Wkk-vorm } & \multirow{2}{*}{\multicolumn{5}{|c|}{$\begin{array}{l}\text { Areaal (ha) b) } \\
\text { vermogen b) }\end{array}$}} & \multicolumn{8}{|c|}{ Reductie $\mathrm{CO}_{2}$-emissie (Mton) } \\
\hline & & & & & & \multicolumn{4}{|c|}{ sector/IPCC } & \multicolumn{4}{|c|}{ nationaal/primair brandstof } \\
\hline & 2010 & 2015 & 2017 & 2018 & $2019 v$ & 2010 & 2017 & 2018 & $2019 \mathrm{v}$ & 2010 & 2017 & 2018 & $2019 v$ \\
\hline Wkk-tuinder & $2.308 \mathrm{MWe}_{\mathrm{e}}$ & $2.396 \mathrm{MWe}_{\mathrm{e}}$ & $2.404 \mathrm{MWe}_{\mathrm{e}}$ & $2.424 \mathrm{MWe}_{\mathrm{e}}$ & $2.546 \mathrm{MWe}_{\mathrm{e}}$ & $-2,60$ & $-2,48$ & $-2,58$ & $-2,83$ & 1,88 & 1,56 & 1,54 & 1,60 \\
\hline Restwarmte a) & 430-450 ha & $470-480$ ha & 470-510 ha & $470-490$ ha & 480-51 ha & 0,199 & 0,199 & 0,185 & 0,153 & 0,142 & 0,153 & 0,143 & 0,117 \\
\hline $\begin{array}{l}\text { Wkk-warmte } \\
\text { energiebedrijven }\end{array}$ & $102 \mathrm{MWe}$ & $22 \mathrm{MWe}_{\mathrm{e}}$ & $10 \mathrm{MWe}$ & $10 \mathrm{MWe}_{\mathrm{e}}$ & $0 \mathrm{MWe}$ & 0,091 & 0,002 & 0,001 & 0 & 0,061 & 0,001 & $<0,001$ & 0 \\
\hline Totaal & b) & b) & b) & b) & b) & $-2,31$ & $-2,28$ & $-2,39$ & $-2,68$ & 2,08 & 1,71 & 1,68 & 1,72 \\
\hline
\end{tabular}

$v$ = voorlopig cijfer

a) exclusief aandeel duurzaam; b) door het gebruik van meerdere wkk-vormen op hetzelfde areaal is sommatie niet mogelij54 
Wageningen Economic Research Postbus 29703

2502 LS Den Haag

T 0703358330

Ecommunications.ssg@wur.nl

www.wur.nl/economic-research

Wageningen Economic Research RAPPORT

2020-109
De missie van Wageningen University \& Research is 'To explore the potential of nature to improve the quality of life'. Binnen Wageningen University \& Research bundelen Wageningen University en gespecialiseerde onderzoeksinstituten van Stichting Wageningen Research hun krachten om bij te dragen aan de oplossing van belangrijke vragen in het domein van gezonde voeding en leefomgeving. Met ongeveer 30 vestigingen, 6.500 medewerkers ( $5.500 \mathrm{fte})$ en 12.500 studenten behoort Wageningen University \& Research wereldwijd tot de aansprekende kennisinstellingen binnen haar domein. De integrale benadering van de vraagstukken en de samenwerking tussen verschillende disciplines vormen het hart van de unieke Wageningen aanpak. 



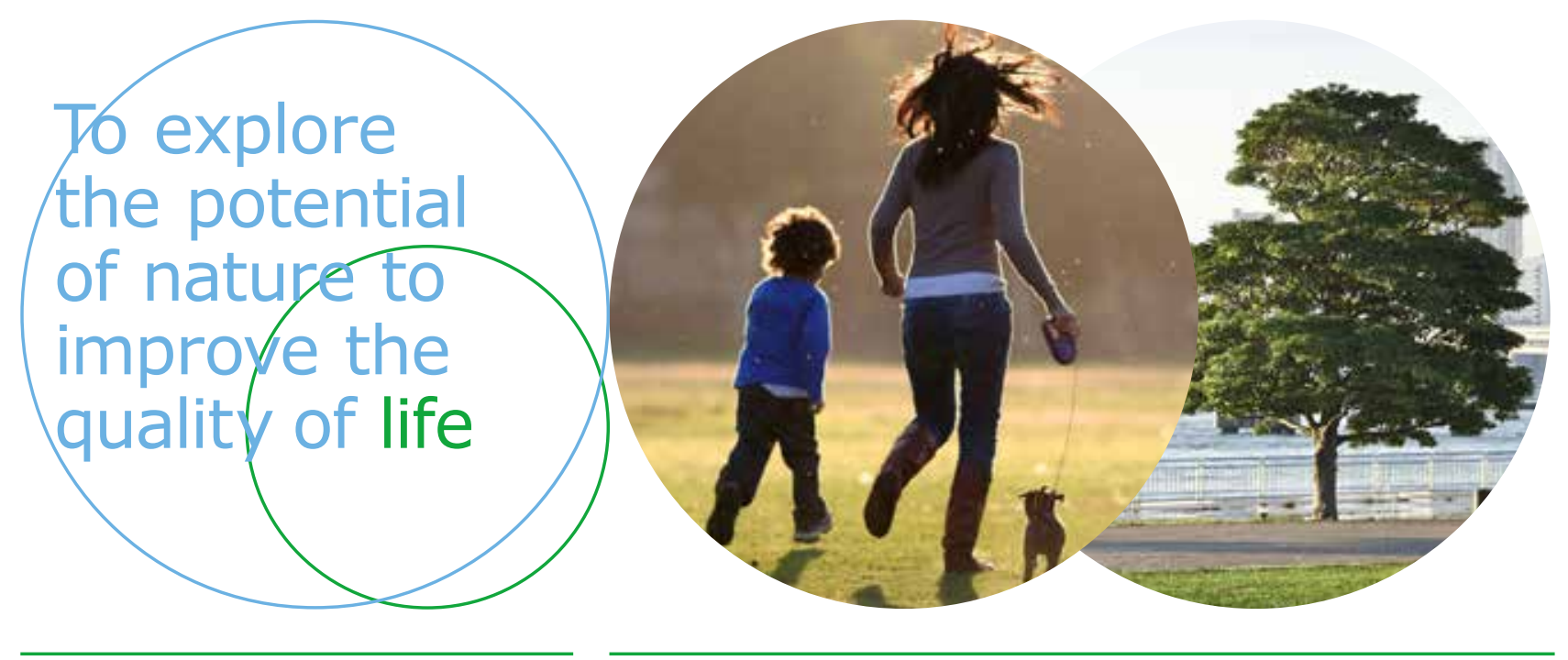

Wageningen Economic Research Postbus 29703

2502 LS Den Haag

T 0703358330

E communications.ssg@wur.nl www.wur.nl/economic-research

Rapport 2020-109

ISBN 978-94-6395-598-0
De missie van Wageningen University \& Research is 'To explore the potential of nature to improve the quality of life'. Binnen Wageningen University \& Research bundelen Wageningen University en gespecialiseerde onderzoeksinstituten van Stichting Wageningen Research hun krachten om bij te dragen aan de oplossing van belangrijke vragen in het domein van gezonde voeding en leefomgeving. Met ongeveer 30 vestigingen, 6.500 medewerkers ( $5.500 \mathrm{fte}$ ) en 12.500 studenten behoort Wageningen University \& Research wereldwijd tot de aansprekende kennisinstellingen binnen haar domein. De integrale benadering van de vraagstukken en de samenwerking tussen verschillende disciplines vormen het hart van de unieke Wageningen aanpak. 